Brooklyn Law School

BrooklynWorks

Faculty Scholarship

2010

Beyond Innovation and Competition: The Need for Qualified

Transparency in Internet Intermediaries

Frank Pasquale

Follow this and additional works at: https://brooklynworks.brooklaw.edu/faculty

Part of the Internet Law Commons 


\section{BEYOND INNOVATION AND COMPETITION: THE NEED FOR QUALIFIED TRANSPARENCY IN INTERNET INTERMEDIARIES}

\section{Frank Pasquale}

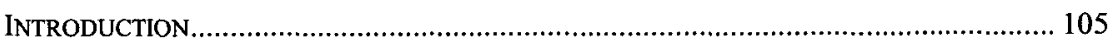

I. THE PROBLEM OF UNACCOUNTABLE INTERMEDIARIES......................................... 110

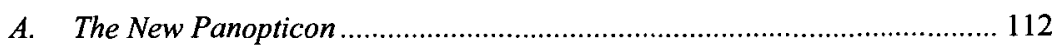

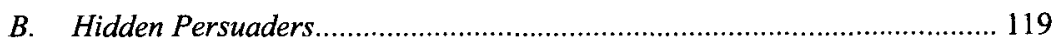

II. COMPETITION AND INNOVATION AS Foundations OF INTERNET POLICY ............... 124

A. Net Neutrality as Innovation Policy.................................................... 128

B. Search Policy as Competition Promotion ................................................. 136

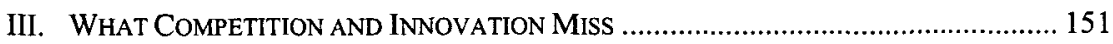

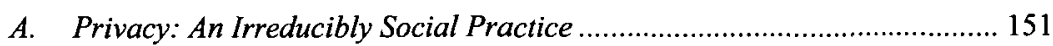

B. Search and Carriage as Credence Goods .............................................. 154

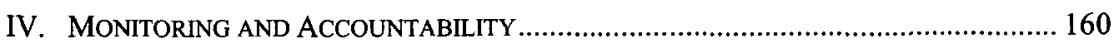

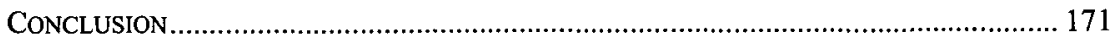

\section{INTRODUCTION}

Internet intermediaries govern online life.' Internet service providers (ISPs) and search engines are particularly central to the web's ecology. Us-

\footnotetext{
* Loftus Professor of Law, Seton Hall Law School; Associate Director of the Center for Health and Pharmaceutical Law and Policy, Seton Hall University. I wish to thank the following institutions and conferences for giving me the chance to present aspects of this work: Intellectual Property Scholars Conference at Stanford Law School; the University of Montreal Conference "Is eCommerce Law Different?"; the Fordham Law School Faculty Workshop; the Annenberg School of Communications Colloquium on New Media and Technology (at the University of Pennsylvania); the Wharton School of Business Colloquium on Media and Communications Law; the State of the Net West Policy Conference at Santa Clara Law School; the University of Chicago Conference on the Internet, Free Speech, and Privacy; and the Computers, Freedom, and Privacy Conference at Yale University. I am also grateful to Seton Hall Law School's summer research fund for supporting this project. I wish to particularly thank Barbara Cherry, Danielle Citron, James Grimmelmann, Brett Frischmann, Michael Madison, Marina Lao, Paul Ohm, Joel Reidenberg, Jean-Baptiste Bruner, Michael P. Van Alstine, Julie Cohen, Simon Stem, and Lauren Gelman for their feedtack on drafts and presentations. Stephen Gikow, Margot Kaminski, Zachary Marco, Labinot Berlajolli, and Jordan T. Cohen provided excellent research assistance, and the library staff at the Yale Law Library and the Seton Hall Law Library were extraordinarily helpful.

${ }^{1}$ For a definition of intermediary, see Thomas F. Cotter, Some Observations on the Law and Economics of Intermediaries, 2006 MICH. ST. L. REV. 67, 68-71 ('[A]n 'intermediary' can be any entity that
} 
ers rely on search services to map the web for them and use ISPs to connect to one another. Economic sociologist David Stark has observed that "search is the watchword of the information age." ISPs are often called "carriers" to reflect the parallel between their own services in the new economy and transportation infrastructure. As the dominant search engine in the United States, Google frequently portrays its services as efficient, scientific, and neutral methods of organizing the world's information.

Yet metaphors of transport and mapping obscure as much as they reveal. While everyone can understand the process of moving from one place to another on a map, delivering bits and ranking websites is a far more complex process. That complexity can often allow Internet intermediaries to conceal their methods and operations from public scrutiny. Google's secrecy about its website-ranking algorithm is well-known. ${ }^{3}$ The Federal Communications Commission (FCC) found that another intermediaryComcast (the nation's largest broadband service provider)-obscured its network management practices. ${ }^{4}$ It took a dogged engineer and investigative reporters months of sleuthing to provoke the agency to investigate. ${ }^{5}$

enables the communication of information from one party to another. On the basis of this definition, any provider of communications services (including telephone companies, cable companies, and Internet service providers) qualify as intermediaries."). This Article focuses on the intermediary role of carriers and search engines.

2 DAVID STARK, ThE SENSE OF Dissonance: Accounts of WORTH IN ECONOMIC Life 1 (2009) ("Among the many new information technologies that are reshaping work and daily life, perhaps none are more empowering than the new technologies of search.... Whereas the steam engine, the electrical turbine, the internal combustion engine, and the jet engine propelled the industrial economy, search engines power the information economy.").

3 See, e.g., Richard Waters, Unrest Over Google's Secret Formula, FIN. TIMES, July 11, 2010 ("Prompted by three complaints, the European Commission this year began an informal investigation, the first time that regulators have pried into the inner workings of the technology that lies at the heart of Google."). This article suggests that U.S. regulators should consider a similar response.

${ }^{4}$ In re Formal Complaint of Free Press and Public Knowledge Against Comcast Corporation for Secretly Degrading Peer-to-Peer Applications, 23 F.C.C.R. 13028 (2008) [hereinafter FCC Comcast Decision] (mem. op. and order). The Court of Appeals for the D.C. Circuit later found that the Commission lacked "authority to regulate an Internet service provider's network management practices." Comcast Corp. v. FCC, 600 F.3d 642, 644 (D.C. Cir. 2010). The Commission has responded by initiating a Notice of Inquiry that could presage a new agency classification of "broadband Internet service" that would give the Commission authority to regulate here. In the Matter of Framework for Broadband Internet Service, GN Docket No. 10-127 1 (June 17, 2010), available at http://hraunfoss.fcc.gov/edocs_public/ attachmatch/FCC-10-114A1.pdf ("This Notice begins an open, public process to consider the adequacy of the current legal framework within which the Commission promotes investment and innovation in, and protects consumers of, broadband Internet service."). This Article challenges the primacy of "investment" and "innovation" concerns in FCC policymaking.

${ }^{5}$ For a concrete example of the type of investigation required to detect problematic network management practices, see Daniel Roth, The Dark Lord of Broadband Tries to Fix Comcast's Image, WIRED, Jan. 19, 2009, at 54, available at http:/www.wired.com/techbiz/people/magazine/1702/mf_brianroberts ("It took [a disgruntled Comcast customer] six weeks of short-burst sleuthing [to conclude that] Comcast appeared to be blocking file-sharing applications by creating fake data packets that interfered with trading sessions [because] [t]he packets were cleverly disguised to look as if they were coming from the user, not the ISP."). 
The average customer is not capable of detecting many important forms of problematic conduct by intermediaries. If intermediary misconduct only negatively affects third parties, users have almost no incentive even to try to detect it. ${ }^{6}$

Legal scholars and policymakers have recognized these problems, and usually promote competition and innovation as their solutions. ${ }^{7}$ If a dominant carrier or search engine is abusing its position, market-oriented scholars say, economic forces will usually solve the problem, ${ }^{8}$ and antitrust law can step in when they don't. ${ }^{9}$ Even those who favor net neutrality rules for carriers are wary of applying them to other intermediaries. ${ }^{10}$ All tend to assume that the more "innovation" happens on the Internet, the more choices users will have and the more efficient the market will become. ${ }^{11}$ Yet these scholars have not paid enough attention to the kind of innovation that is best for society, and whether the uncoordinated preferences of millions of web users for low-cost convenience are likely to address the cultural and political concerns that dominant intermediaries raise.

Part I of this Article investigates the noneconomic threats that dominant intermediaries pose, particularly in terms of privacy, reputation, and democratic culture. Many of the threats traditionally associated with ISPs are also posed by search engines - and vice versa. ${ }^{12}$ As the convergence of

${ }^{6}$ For example, if a searcher is indifferent to a certain range of results that a search engine produces, but the search engine unfairly discriminates among the ranking of the results in that range, neither the searcher nor the search engine has an incentive to stop the discrimination. In a world of satisficing searchers, the possible range of results could be large for many queries. Moreover, as search results are increasingly personalized, searched-for entities have a less clear idea of whether their sites are actually reaching searchers.

${ }^{7}$ See infra text accompanying note 101.

${ }^{8}$ See, e.g., Douglas A. Hass, The Never-Was-Neutral Net and Why Informed End Users Can End the Network Neutrality Debates, 22 BERKELEY TECH. L.J. 1565, 1569, 1620-28 (2007) (describing "the inherent enforcement difficulties in preemptive or ex post neutrality regulation," and doubting the utility of antitrust law).

${ }^{9}$ See, e.g., Daniel F. Spulber \& Christopher S. Yoo, Mandating Access to Telecom and the Internet: The Hidden Side of Trinko, 107 COLUM. L. REV. 1822, 1904 (2007) ("Just as the existence of alternative sources of network capacity undercuts the justification for platform access on behalf of information services, so too does competition between cable modem and DSL systems and the imminent emergence of other broadband alternatives undercut the justification for imposing network neutrality.").

${ }^{10}$ See, e.g., Gigi Sohn, Another Red Herring, PuB. KNOWLEDGE, June 5, 2006, http://www.publicknowledge.org/node/422 ("[I]f we require broadband network providers not to discriminate in favor of content, applications and services in which they have a financial interest, should we not require the same from search engines like Google, Yahoo and MSN?... [No, because] while Google and Yahoo may be the most popular search engines, there are many others to choose from, unlike the market for broadband network providers ...."). I address the limitations of an individualistic, consumer perspective on the issue later in this Article.

1 See infra text accompanying note 101 .

12 See Nicholas P. Dickerson, What Makes the Internet So Special? And Why, Where, How, and by Whom Should Its Content Be Regulated?, 46 Hous. L. REV. 61, 90-91 (2009) ("The policies of Google ... represent a glaring example of corporate abuse of regulatory power. . . Google has become a crucial method of expression for anyone actively seeking to disseminate information on the Internet. 
voice and data on common "pipes" (or wireless connections) accelerates, the joint ventures of leading Internet companies will raise a new host of concerns about privacy, culture, and power online. A troubling asymmetry has developed: as dominant intermediaries gather more information about users, users have less sense of exactly how life online is being ordered by the carriers and search engines they rely on.

Part II surveys the mainstream of communication and Internet scholarship addressing this asymmetry. Deregulationists claim that undue discrimination or invasive surveillance will cost an entity customers-and to the extent market power forecloses that exit option, antitrust law is remedy enough. ${ }^{13}$ Were new concerns about intermediaries wholly economic in nature, such assurances might be persuasive. However, as Part III shows, the cultural, political, and privacy concerns raised by search engines and carriers cannot be translated into traditional economic analysis. They raise questions about the type of society we want to live in-a holistic inquiry that cannot be reduced to the methodological individualism of neoclassical economics. $^{14}$

Fortunately, the information asymmetry between users and carriers has been addressed in some agency actions. The FCC has begun to enforce "net neutrality" via adjudication in order to proscribe certain forms of discrimination by carriers. ${ }^{15}$ The Federal Trade Commission (FTC) has issued guidance to search engines indicating that they need to clearly distinguish

\footnotetext{
Unfortunately, Google has taken advantage of this power to determine which Internet speakers are heard by refusing to accept many sponsored links simply because they fit Google's broad category of content constituting 'advocacy against any individual, group, or organization.' Pursuant to this policy, Google has refused to host many political, religious, or socially critical advertisements as well as the websites to which these advertisements link. Google has thereby effectively, if not actually, silenced a great deal of Internet speech." (footnotes omitted)); Frank Pasquale, Internet Nondiscrimination Principles: Commercial Ethics for Carriers and Search Engines, 2008 U. CHI. LEGAL F. 263, 264 (favoring both net neutrality and some forms of search neutrality); Andrew Odlyzko, Network Neutrality, Search Neutrality, and the Never-Ending Conflict Between Efficiency and Fairness in Markets 2 (Jan. 27, 2009), available at http://ssm.com/abstract=1095350 ("Should something like net neutrality prevail, the conflict would likely move to a different level. That level might become search neutrality.”).

${ }^{13}$ See infra text accompanying notes 114-115.

14 As James R. Hackney, Jr., writes, "[T]here is no longer [a] viable claim to the epistemological superiority of law and neoclassical economics .... The hegemony of legal-economic thought has come to an end, and the field is also more diverse internally." JAMES R. HACKNEY, JR., UNDER COVER OF SCIENCE: AMERICAN LEGAL-ECONOMIC THEORY AND THE QUEST FOR OBJECTIVITY 166 (2007). As behavioral economics increasingly embraces insights from psychology, a general trend toward the unification of the social sciences can be observed. For example, Robert Shiller has noted the urgency of alternative approaches in the discipline. See Louis Uchitelle, Two Americans Are Awarded Nobel in Economics, N.Y. TIMEs, Oct. 12, 2009, at B1. Shiller asserts that the award of the Nobel Prize in economics to Elinor Ostrom and Oliver Williamson "is part of the merging of the social sciences. Economics has been too isolated and too stuck on the view that markets are efficient and self-regulating. It has derailed our thinking." Id.

${ }^{15}$ See FCC Comcast Decision, supra note 5.
} 
between paid and unpaid results. ${ }^{16}$ While these are respectable first steps, neither agency has fully committed to an agenda of net neutrality or search engine accountability. More troublingly, neither appears to have the institutional capacity to truly understand whether carriers or search engines are defying relevant agency guidance or abandoning their own avowed business practices.

Where do we go from here? Public interest groups have made some inroads in holding ISPs accountable, and will soon have no choice but to confront Google's dominance. ${ }^{17}$ The same obstacles to holding Google accountable (trade secret protection for its ordering algorithms) may also interfere with network neutrality regulation. Like search engines, carriers face an information overload problem, with spam, viruses, and highdemand applications threatening to overwhelm their networks. ${ }^{18}$ They are likely to make key network-management practices as confidential as search engine rankings, and trade secret protection has already been deployed in other technological settings to block critical review of questionable corporate behavior. ${ }^{19}$

Part IV develops a regulatory response to these problems, focusing on the current and growing asymmetry of information between intermediaries and those trying to reach one another via the web. The first step toward accountability is transparency. Key regulators at the FTC and FCC need to fully understand how carriers manage networks and how dominant search

${ }^{16}$ See Div. OF AdVER. PRACTICES, FTC, RE: COMPLAINT REQUESTING INVESTIGATION OF VARIOUS INTERNET SEARCh ENGINE COMPANIES for PAID PlaCEMENT AND PAID INCLUSION PROGRAMS (June 27, 2002), available at $\mathrm{http}: / / \mathrm{www} . f t c . g o v / o s / c l o s i n g s / \mathrm{staff} /$ commercialalertletter.htm (FTC Response to Commercial Alert); FTC DOT COM DisclosurEs: INFORMATION ABOUT ONLINE ADVERTISING, (May 2000), available at http://www.ftc.gov/bcp/edu/pubs/business/ecommerce/bus41.pdf [hereinafter FTC, Dot COM Disclosures]; see also Div. OF ADVER. Practices, FTC, RE COMMERCIAL Alert COMPLAINT REQUESTING INVESTIGATION OF VARIOUS INTERNET SEARCH ENGINE COMPANIES FOR PAID PLACEMENT AND PAID INCLUSION PROGRAMS (June 27, 2002), available at http:/www.ftc.gov/os/ closings/staff/commercialalertattatch.shtm (FTC Letter to Search Engine Companies).

${ }^{17}$ See Electronic Privacy Information Center (EPIC), Privacy? Proposed Google/DoubleClick Merger, http://epic.org/privacy/ftc/google/ (last visited Mar. 1, 2010); see also note 183 and accompanying text. Calls for regulation of search have largely come from academics and programmers. See, e.g., Viva R. Moffat, Regulating Search, 22 HARV. J. L. \& TECH. 475, 488 (2009) ("Professor Frank Pasquale has led the charge in arguing for ... more intensive regulation of search engines."); Drake Bennett, Stopping Google: With One Company Now the World's Chief Gateway to Information, Some Critics Are Hatching Ways to Fight Its Influence, BOSTON GLOBE, June 22, 2008, at $\mathrm{K} 1$, available at $\mathrm{http} / /$ www.boston.com/bostonglobe/ideas/articles/2008/06/22/stopping_google ("[A] number of scholars and programmers have begun to argue that the company is acquiring too much power over our lives-invading our privacy, shaping our preferences, and controlling how we learn about and understand the world around us.").

${ }^{18}$ For theoretical perspectives on the problem of information overload, see Frank Pasquale, Copyright in an Era of Information Overload, 60 VAND. L. REV. 135, 169-72 (2007) ("[A]ny bit of expression that signals something to one who wants exposure to it may constitute noise to thousands of others.').

19 See infra text accompanying notes 306-312. 
engines map the web. Given legitimate needs for secrecy, this monitoring need not be transparent to all-just to the relevant regulators charged with maintaining the integrity of networks and search. Like the Foreign Intelligence Surveillance Court developed in the national security context, monitors at the FCC and the FTC would balance intermediaries' need for confidentiality with a public need for accountability. Developing such monitoring is the first step toward assuring responsible Internet intermediaries.

\section{ThE PROBLEM OF UNACCOUNTABLE INTERMEDIARIES}

Scholars have long recognized the political and cultural power of the media in democratic societies. ${ }^{20}$ Elections have been won and lost based on impressions of candidates generated on broadcast television. Radio stations have had extraordinary power over the careers of new recording artists. Newspapers have driven civic agendas.

Each of these old media still perform important functions today, but their power is waning. Traditional journalism is in crisis. ${ }^{21}$ Some financial experts expect that reporting will be sustainable only if it is endowed like a charity or university. ${ }^{22}$ Broadcast media are in less serious financial trouble, but find their political and cultural clout declining and their profit margins threatened. ${ }^{23}$ A secular trend toward narrowcasting has intensified on the web, as more individuals forsake appointment television for the "long tail" of online content. ${ }^{24}$ Though its role in some conservative political and reli-

20 See, e.g., Doris A. GRaber, Mass Media AND AMERICAN Politics 206 (1980); Doris A. Graber, Processing the News: How PEOPle Tame the Information Tide 1-2 (1993); Thomas E. PatTERSON, Out OF ORDER 210 (1993); John R. Petrocik, Campaigning and the Press: The Influence of the Candidates, in DO THE MEDIA GoveRN? 181, 184-85 (Shanto Iyengar \& Richard Reeves eds., 1997) (discussing the agenda-setting power of the media).

21 Bruce Ackerman \& Ian Ayres, A National Endowment for Journalism, GUARDIAN, Feb. 13, 2009, http://www.guardian.co.uk/commentisfree/cifamerica/2009/feb/12/newspapers-investigative-joum alism-endowments/print ("The traditional newspaper is dying."); Jacob Weisberg, The New Hybrids: Why the Debate About Financing Journalism Misses the Point, SLATE, Feb. 21, 2009, http://www.slate.com/id/2211678 (describing the "somy predicament of the newspaper industry").

${ }^{22}$ All the News That's Free to Print: Is Charity the Newspaper Industry's Last, Best Hope?, ECONOMIST, July 21, 2009, available at http://www.economist.com/businessfinance/displaystory.cfm? story_id=14072274.

${ }^{23}$ Bob Garfield, THE ChaOS SCENARIo 10 (2009) (arguing that traditional thirty-second ads and other staples of the broadcast business model are increasingly irrelevant to marketing, rendering "TV as we know it ... fundamentally doomed"); Tim Arango, Broadcast TV Faces Struggle to Stay Viable, N.Y. TIMES, Feb. 28, 2009, at Al ("Ratings over all for broadcast networks continue to decline, making it harder for them to justify their high prices for advertising. ... For the retworks, the crisis is twofold: cultural and financial.").

${ }^{24}$ ChRIS ANDERSON, THE LONG TAIL 18 (2006) ("[W]ith online distribution and retail, we are entering a world of abundance."). 
gious groups is as strong as ever, ${ }^{25}$ radio generally has become less culturally relevant as younger listeners turn to digital venues for music. ${ }^{26}$

All of these developments have coincided with - and have in part been caused by - the rise of new media, which feature online video, text, and music. New intermediaries organize and control access to these offerings. Content providers aim to be at the top of Google Search or Google News results. ${ }^{27}$ Services like iTunes, Hulu, and YouTube offer audio and video content. Social networks are extending their reach into each of these areas. ${ }^{28}$ Cable-based ISPs like Comcast have their own relationships with content providers. ${ }^{29}$

When an Internet connection is dropped, or a search engine fails to produce a result the searcher knows exists somewhere on the web, such failures are obvious. However, most web experiences do not unfold in such a binary, pass-fail manner. An ISP or search engine can slow down the speed or reduce the ranking of a website in ways that are very hard for users to detect. Moreover, there are many points of control, or layers, of the web. ${ }^{30}$ Even when a user's experience causes suspicion, it is easy for any blamed layer to shift responsibility to another entity.

Were carriers or search engines merely neutral infrastructure or maps, such alterations of online experience might not be a concern of the law. However, the new power of intermediaries over reputation and visibility

25 Jim Puzzanghera, Democrats Speak Out for Fairness Doctrine, L.A. TIMES, July 23, 2007, at C1, available at http://www.c3.ucla.edu/newsstand/media/a-push-for-reinstatement-of-the-fairness-doctrine/ (discussing the power of conservative talk radio).

${ }^{26}$ See Posting of Larry Johnson to Paragon Media Strategies Blog, 2nd Annual Youth Radio \& New Media Study: Not Much More Damage iPods Can Do to Radio TSL, http:/www.paragonmediastrategies.com/theblog/?p=355\#more-355, (Sept. 17, 2008, 22:28 EST) ("iPod ownership is practically universal: $85 \%$ of 18-24 year olds own an iPod or portable MP3 device.").

27 See Deborah Fallows \& LeE Rainie, Pew Internet \& Am. Life ProJect, Data Memo: The POPULARITY AND IMPORTANCE OF SEARCH ENGINES 2 (Aug. 2004), http:/www.pewinternet.org/pdfs/PIP_Data_Memo_Searchengines.pdf ("The average visitor scrolled through 1.8 result pages during a typical search."); Leslie Marable, False Oracles: Consumer Reaction to Learning the Truth About How Search Engines Work: Results of an Ethnographic Study, CONSUMER WEBWATCH, June 30,2003, at 5, available at http://www.consumerwebwatch.org/pdfs/false-oracles.pdf ("The majority of participants never clicked beyond the first page of search results. They trusted search engines to present only the best or most accurate, unbiased results on the first page.").

${ }^{28}$ Albert-LÁszló BarabÁSI, LINKED: THE NEW SCIENCE OF NETWORKS 19 (2002) (describing the exponentially increasing value of nodes in a network as it encompasses more participants).

29 RoBert W. MCChESNEY, Rich MEDIA, POOR DEMOCRACY: COMMUNICATION POLITICS IN DUBIOUS TIMES $123(2000)$ (describing how convergence of digital technology "eliminates the traditional distinctions between media and communications sectors").

30 JONATHAN ZITTRAIN, THE FUTURE OF THE INTERNET-AND HOW TO STOP IT 67 (2008) (describing a physical layer, the "actual wires or airwaves over which data will flow;" an application layer, "representing the tasks people might want to perform on the network;" a content layer, "containing actual information exchanged among the network's users;" and a social layer, "where new behaviors and interactions among people are enabled by the technologies underneath"). 
implicates several traditional concerns of the American legal system. ${ }^{31}$ Section A describes the power of intermediaries not only to monitor and track what users do, but also to generate reputations based on that data. While extant employment and credit reporting law regulates some entities which generate and rely on background checks, no similar restrictions apply to many sources of online data. ${ }^{32}$ Section $B$ shows how the power of intermediaries affects the other side of the web equation: users' view of the online world. While older communications law and policy addressed this issue in many ways, Internet intermediaries are presently bound only by weak and inadequate enforcement of consumer protection and false advertising statutes.

\section{A. The New Panopticon}

As Google gains market share, ${ }^{33}$ it has become a de facto lawmaker for many aspects of life on the Internet. ${ }^{34}$ Google aspires to amass a comprehensive "database of intentions" of its users, many of whom have expressed concerns about the misuse of such data. ${ }^{35}$ But these well-publicized anxieties overlook two important lessons of the privacy and intermediaries story. First, ISPs pose at least as great a threat to privacy as Google does, as they have the opportunity to collect data not just on searches, but on all their users' time on the web. ${ }^{36}$ Second, privacy itself has faded in importance in

31 Yochai Benkler, Communications Infrastructure Regulation and the Distribution of Control over Content, 22 TELECOMM. POL'Y 183, 185-86 (1998) (describing the power of intermediaries over information flow: "technology, institutional framework, and organizational adaptation . . . determine . . . who can produce information, and who may or must consume, what type of information, under what conditions, and to what effect"); Cotter, supra note 1, at 69-71 (discussing some of the functions of technological intermediaries, including their control of information flow from suppliers to consumers).

${ }^{32}$ Robert Sprague, Googling Job Applicants: Incorporating Personal Information into Hiring Decisions, 23 LAB. LAW. 19, 38 (2007) (stating that Internet searches allow prospective employers to discover candidate information that would be prohibited through traditional prescreening mediums); Robert Sprague, Rethinking Information Privacy in an Age of Online Transparency, 25 HoFSTRA LAB. \& EMP. L.J. 395, 399 (2008) (stating that the Internet provides a useful alternative to traditional prescreening techniques which are restricted by various laws); Thomas F. Holt, Jr. \& Mark D. Pomfret, Finding the Right Fit: The Latest Tool for Employers, METRO. CORP. COUNS., Nov. 2006, at 29 (discussing the legal implications of using Internet searches as a tool for screening job applicants).

${ }^{33}$ Randall Stross, Everyone Loves Google, Until It's Too Big, N.Y. TIMES, Feb. 21, 2009, at BU3 (noting that Google's "market share gains have ... been accelerating ... [so that it now has] 72 percent of the United States market, versus 17.9 percent for Yahoo").

${ }^{34}$ See, e.g., Greg Lastowka, Google's Law, 73 BrooK. L. REV. 1327, 1410 (2008) ("Google currently occupies a central role in online commerce and information retrieval.").

35 John Battelle, THE SEARCH: HOW GOOgLE aNd ITS RIVAls Rewrote tHE Rules of BUSINESS AND TRANSFORMED OUR CULTURE 4 (2005) (describing the company's effort to "leverage [a] [d] atabase of Intentions in a commercial manner").

${ }^{36}$ Paul Ohm, The Rise and Fall of Invasive ISP Surveillance, 2009 U. ILL. L. REV. 1417, 1420 (arguing that "nothing in society poses as grave a threat to privacy as the ISP, not even Google" because "an ISP can always access even more [personal information] because it owns and operates ... the only point on the network that sits between a user and the rest of the Internet. ... [so] a user cannot say any- 
comparison with reputation. ${ }^{37} \mathrm{~A}$ critical mass of doctrine in intellectual property and privacy law (along with established patterns of consumer behavior) has freed up a variety of previously unreachable information. As a consequence, law now must concern itself not only with information's accumulation or flow, but with what results from that information: the rankings, recommendations, or ratings derived from it. ${ }^{38}$

Rumors about a person's sexual experiences, health status, incompetence, or nastiness can percolate in blogs and message boards for years. Search engines can then increase the salience of such information, making a single mistake or scandal the dominant image of a person online. ${ }^{39}$ Even more chillingly, the subject of such innuendo may never know its influence on important decisionmakers. While many web users assume that they understand how the results generated by their name or business appear generally, we are really only aware of how such results are presented to us individually. Personalization permits search engines to present customtailored results based on users' past behavior. ${ }^{40}$

In order to understand the dangers such automated reputation creation poses, consider each of the scenarios below:

(1) Imagine applying for a job, wanting to be sure to give the right impression. A diligent self-googler, you think you know everything there is out there on the web about you. Nothing sticks out in the first fifteen or so pages of results. ${ }^{41}$ But there is someone with a name identical to yours who has a terrible reputation. When the human resources department queries

thing to Google without saying it first to his ISP"). For a technical description of the movement of such data, see Jonathan Zittrain, Internet Points of Control, 44 B.C. L. REV. 653, 657 (2003) ("Thus we might think of typical movement of data on the Internet as having five distinct phases. It begins at (1) a source, passes through (2) the source ISP, continues through transit and/or peering through (3) the cloud, is handled by (4) the destination ISP and then arrives at (5) the destination.").

${ }^{37}$ See generally DANIEL J. SOlOVE, THE FUTURE OF REPUTATION: GOSSIP, RUMOR, AND PRIVACY ON THE INTERNET (2007) (placing reputational effects at the center of privacy concerns).

38 Jonathan Zittrain, Privacy 2.0, 2008 U. CHI. LEGAL F. 65, 81-84 (describing power of intermediaries to enable new forms of reputation creation by making documented behaviors "reviewable by the public at large").

39 Michael Zimmer, Privacy on Planet Google: Using the Theory of "Contextual Integrity" to Clarify the Privacy Threats of Google's Quest for the Perfect Search Engine, 3 J. BuS. \& TECH. L. 109, 120 (2008) ("It is no longer acceptable to hide behind the rhetoric that no private information is divulged when utilizing the tools that make up the perfect search engine, or that the information shared is simply the same as that provided in other information-seeking scenarios.").

${ }^{40}$ Rahul Telang et al., An Empirical Analysis of Internet Search Engine Choice 25 (Darden Graduate Sch. of Bus. Admin., Univ. of Va., Working Paper No. 03-05, 2001), available at http://papers.ssm.com/sol3/papers.cfm?abstract_id=412782 (finding the effect of loyalty is small when users use engines for "simple search," but that "loyalty formation . . . becomes highly significant when the users start using personalized features").

41 Note that even these "vanity searches" may create privacy problems themselves. Christopher Soghoian, The Problem of Anonymous Vanity Searches, 3 I/S: J.L. \& POL'Y FOR INFO. SOC'Y 299, 302 (2007) (noting that the Electronic Frontier Foundation advised "never to search for information on oneself' because such a search potentially compromises the privacy of the rest of one's searches). 
Google with your name, that is the first set of results it sees. They have optimized their background check to focus on keywords like "arrest" and "assault;" you have not trained your own search engine to focus on such keywords. You are never given a reason for being turned down for the job, but instead receive only a brief form letter.

(2) In a variation on the first scenario, imagine you had a bankruptcy or foreclosure twenty years ago. It has been wiped off your credit reports, but data miners put a record of the bankruptcy online, seeking to attract those who might be interested in purchasing a more complete report about you. After the data miners hire search engine optimizers to increase the prominence of their sites, this record becomes the first-ranking result in searches for your name. A digital scarlet letter removed from credit reports-which potential creditors, landlords, and employers had to pay for-is now freely available for anyone on the web to inspect.

(3) Next, imagine there are thousands of results about you or people with names similar to yours, and you never see the record of the bankruptcy. But when you apply for a job, the Human Resources department has "personalized" its results to assure that the most damaging information available about a person comes up first. You would also have to avail yourself of this sort of personalizing software to be fully aware of all the negative information such personalized searches generate. Yet trade secrecy and exclusive licensing deals prevent you from ever accessing an exact replica--or even a close facsimile-of the searches used by the educators, employers, landlords, bankers, and others making vital decisions about your future.

(4) Finally, back to a more pedestrian scenario: You are an attorney rated "mediocre" by a lawyer-rating site. When you ask the site to disclose the data the rating is based on, it refuses. It also will not disclose the methodology it uses to compile the data into a single score of your advocacy abilities. If you sue, the company will assert that the First Amendment cloaks it with an absolute immunity to accountability. ${ }^{42}$

As the scenarios above become more common, individuals may reasonably fear that a crucial decisions about their opportunities are being made on the basis of misunderstandings or an unfair and unbalanced information environment. Automated search systems can easily reduce a complex person to one trait, fact, or record, without the reductionism ever being

\footnotetext{
42 See Browne v. Avvo, Inc., 525 F. Supp. 2d 1249, 1251 (W.D. Wash. 2007) (dismissing lawsuit against laywer-rating site Avvo because "the opinions expressed through the rating system . . . are absolutely protected by the First Amendment"); Cliff Tuttle, Say Hello to Avvo, Whether You Like It or Not!, 9 LAW. J. 4, 9 (2007) (stating that Avvo's scores are determined by a secret algorithm); What is the Avvo Rating?, http://www.avvo.com/support/avvo_rating (last visited Mar. 2, 2010) ("The Avvo Rating is based on all of the background information in a lawyer's profile. However, we do not disclose how we weigh this information.").
} 
disclosed. Rumor and innuendo circulating online can also indiscriminately harm the innocent. ${ }^{43}$

Reasonable individuals can differ about the degree to which such harms are deserved and how much autonomy intermediaries should have in gathering data and presenting results. However, there should be some basic protections for those affected by the new automated reputation creation. We can better understand the contours of such protections by articulating the harms involved in each scenario.

The first scenario above is a simple case of mistaken identity, and presumably expedients like social security number matching would prevent it. ${ }^{44}$ Yet the possibility of online mistaken identity cannot be dismissed as an idle worry, in part because the present law surrounding applicant background checks using information from regulated entities may create incentives for such quick and furtive peeks online. ${ }^{45}$ Like the "shoot, shovel, and shut up" response to the Endangered Species Act, ${ }^{46}$ the quick and dirty Google search may become a primary mode of evading the strictures that the Fair Credit Reporting Act imposes on background checks using credit

${ }^{43}$ Danielle Keats Citron, Cyber Civil Rights, 89 B.U. L. REV. 61, 71 (2009) ("[A]ttackers send damaging statements about victims to their employers and manipulate search engines to reproduce the damaging statements and pictures for others to see, creating digital 'scarlet letters' that destroy reputations."); see also SOLOVE, supra note 37, at 203 ("With the use of search engines like Google, employers can conduct amateur background checks without any legal protections [for potential employees].").

44 Many states have laws providing that employees and former employees have a right to inspect files that the employer holds on them. See, e.g., CAL. LAB. CODE $\$ 1198.5$ (West 2003); CONN. GEN. STAT. § 31-128a (2003); ME. REV. STAT. ANN. tit. 26, § 631 (2007); MASS. GEN. LAWS ch. 149, § 52C (2004). Depending on the state law, "file" may include all sorts of documents used to determine an individual's employment, promotion, compensation, transfer, or termination, including in some cases emails and faxes. Records of criminal investigations and letters of reference are often excluded from the disclosure-access requirement. See, e.g., CAL. LAB. CODE $\$ 1198.5$.

45 See Gaye Bunderson, Peering into the Past..., IDAHo BUS. REV., Mar. 24, 2008, available at http://www.idahobusiness.net/archive.htm/2008/3/24/Peering-into-the-past- ("The cost of not having background checks is a higher consequence to the bottom line than paying a small fee for a background check ... . Employers can be held financially and criminally liable for the actions of an employee. Establishing a pre-employment screening program can protect an employer against potential liability." (internal quotation marks omitted)); see also Donald Carrington Davis, MySpace Isn't Your Space: Expanding the Fair Credit Reporting Act to Ensure Accountability and Fairness in Employer Searches of Online Social Networking Services, 16 KAN. J.L. \& PUB. POL'Y 237, 239 (2007) ("Many employers consider searching a candidate's MySpace or Facebook profile an inexpensive and convenient peek into the candidate's life and character. Until recently ... online social networking users remained generally unaware of the fact that many employers were rejecting them because of something the employer found on their MySpace profile." (footnotes omitted)).

${ }^{46}$ For a description of this law-evading response, see Mollie Lee, Environmental Economics: $A$ Market Failure Approach to the Commerce Clause, 116 YALE L.J. 456, 491 (2006) (discussing incentives to eliminate endangered animals instead of submitting to legal requirements to report on and avoid harming them). 
reports ${ }^{47}$ - unless some version of that law is imposed on important decisionmakers which utilize search engines to conduct internet-based background checks. ${ }^{48}$

The second scenario-involving bankruptcy and foreclosure-is a variation of the first, though this time the information is accurate. The third situation intensifies the harm experienced in the second and comes close to the core of my concerns in this Article. It is one thing to be judged on the basis of a fault you know about; it is a different experience altogether to have no idea what the basis of a negative judgment is. ${ }^{49}$ While such a problem might seem unlikely now, personalized search technology makes ignorance of personally damaging information increasingly possible in the future. As a person uses a search engine, he gradually trains it to prioritize certain types of results and deprioritize others. ${ }^{50}$ This translation of beha-

${ }^{47}$ Sprague, supra note 32, at 30 ("Under the FCRA, employers must notify the applicant in writing if a report is to be obtained [from a credit reporting agency], and employers must notify an applicant if a credit report is used in making an adverse decision ...."); id. at 36 ("Due to the restrictions facing employers in investigating the background of applicants, it is no wonder they have turned to the Internet to investigate prospective employees.").

48 For a proposal along these lines, see Frank Pasquale, Toward a Fair Reputation Reporting Act, in PRIVACY, FREE SPEECH, AND THE INTERNET (Martha Nussbaum \& Saul Levmore eds., forthcoming 2010). For a European precedent, see William McGeveran, Finnish Employers Cannot Google Applicants, INFO/LAW, http://blogs.law.harvard.edu/infolaw/2006/11/15/finnish-employers-cannot-googleapplicants (Nov. 15, 2006) ("The country simply bans employers from googling [sic] applicants. ... The new rule, issued by Finland's Data Protection Ombudsman, represents its official interpretation of the statutory language of the "Act on the Protection of Privacy in Working Life."). See also Council Directive 95/46, On the Protection of Individuals with Regard to the Processing of Personal Data and on the Free Movement of Such Data, 1995 O.J. (L 281) 31 (EC), available at http://eurlex.europa.eu/LexUriServ/LexUriServ.do?uri=CELEX:31995L0046:EN:HTML ("[O]n the protection of individuals with regard to the processing of personal data and on the free movement of such data ...."). This prohibition is part of a larger genus of law in the EU known as "fair information practices." See Paul M. Schwartz, Beyond Lessig 's Code for Internet Privacy: Cyberspace Filters, Privacy Control, and Fair Information Practices, 2000 WIS. L. REV. 743, 776 (describing the development of fair information practices law).

49 Daniel J. Solove, Privacy and Power: Computer Databases and Metaphors for Information Privacy, 53 STAN. L. REV. 1393, 1393 (2001) (applying Kafka's work to cyberspace and identifying "the problem [as] the powerlessness, vulnerability, and dehumanization created by the assembly of dossiers of personal information where individuals lack any meaningful form of participation in the collection and use of their information").

${ }^{50}$ With personalized search, a search engine can use artificial intelligence and other methods to gradually "learn" what users most likely want given their pattern of responses to past results. For example, if a user habitually searches for recipes, the search engine may weigh food sites more heavily than other sites when confronted with an ambiguous term (such as "cake," which could refer, inter alia, to a confection or to the rock band Cake). Such a sensitive "learning" search engine would save the user the trouble of typing in longer terms like "cake food" or "cake cooking." Someone who never cooks but likes rock music might see the band first; a devoted chef might see recipes first. See James Pitkow, et al., Personalized Search: A Contextual Computing Approach May Prove a Breakthrough in Personalized Search Efficiency, 45 COMM. OF ACM 50, 50 (2002) (discussing methods of personalizing search systems); Elinor Mills, Google Automates Personalized Search, CNET NEws, June 28, 2005, http://www.news.com/Google-automates-personalized-search/2100-1032_3-5766899.html (reporting 
vior into a "database of intentions" helps searchers a great deal, but can create uncertainty and anxiety for a person who becomes the object of others' searches. ${ }^{51}$ While the "investigative consumer reports" (ICRs) generated by credit reporting agencies are subject to several strictures, ${ }^{52}$ personalized searches are not regulated in the United States. Again, the regulatory framework surrounding extant background checks may unfairly induce the use of informal digital methods that increase the chance of misrecognition and reductionism. ${ }^{53}$

One version of the fourth scenario has already generated a good deal of controversy. ${ }^{54}$ The company Avvo aspires to rate all licensed attorneys within the states it covers. ${ }^{55}$ The service is designed to help consumers choose a lawyers by providing information about them. ${ }^{56}$ Each licensed attorney has a profile on the site originally created by Avvo that can be updated with detailed information after it is claimed by the attorney using an identity verification system. ${ }^{57}$

that Google "launched a new version of its personalized search that monitors previous searches to refine future results").

51 For a prescient examination of objectification resulting from reductionism here, see Julie E. Cohen, Examined Lives: Informational Privacy and the Subject as Object, 52 STAN. L. REV. 1373, 1377 (2000) ("Our conceptions of property, choice, and information reinforce one another; under all of them, individuals are treated as the natural and appropriate objects of others' trades, others' choices, others' taxonomies, and others' speech.").

52 ICRs are:

dossiers on consumers that include information on character, reputation, personal characteristics, and mode of living. ICRs are compiled from personal interviews with persons who know the consumer. Since ICRs include especially sensitive information, the FCRA affords greater protections for them. For instance, within three days of requesting an ICR, the requestor must inform the consumer that an ICR is being compiled. The consumer also can request a statement explaining the nature and scope of the investigation underlying the ICR.

Electronic Privacy Information Center, The Fair Credit Reporting Act (FCRA) and the Privacy of Your Credit Report, http://epic.org/privacy/fcra (last visited Mar. 11, 2010).

53 For a fuller description of the harm of reductionism, see Frank Pasquale, Rankings, Reductionism, and Responsibility, 54 CLEV. ST. L. REV. 115 (2006) (discussing the negative impact of partial or misleading results in distorting searchers' impressions of a given queried subject).

${ }^{54}$ See John Cook, Respected Lawyer Wants Rating Site Avvo Closed, SEATTLE POSTINTELLIGENCER, June 12, 2007, at B1, available at http://www.seattlepi.com/business/319410_avvol2 .html ("Steve Berman, one of the best-known class-action attorneys in the country, said .... "[y]ou have consumers who are going to be making decisions about whether or not to hire a lawyer based on a rating system that is completely deceptive.... It is not reliable. It is not based on any valid criteria. And, in fact, the publisher of this site should know there is something wrong."').

${ }^{55}$ Id. Avvo.com claims to be adding more states all the time. The service currently covers twentythree states and the District of Columbia. Current State Coverage-Attorney Directory, http://www.avvo.com/about_avvo/current_states (last visited Mar. 11, 2010).

56 Lawyer Search, http://www.avvo.com/find-a-lawyer (last visited Mar. 11, 2010).

57 For Lawyers, http://www.avvo.com/lawyer-marketing (last visited Mar. 11, 2010). 
The right to claim the profile is a classic example of Web 2.0 business models. ${ }^{58}$ Attorneys listed on the site ignore the profile at their peril, and those critical of Avvo's project are put in a double-bind by the profile's very existence. ${ }^{59}$ To the extent that critics tell "their side of the story" on the profile, they are building up Avvo's database. The aggregator acts like Tom Sawyer, inviting others to "paint the fence" by adding to the store of data that increases its authority and comprehensiveness. ${ }^{60}$

Disgruntled attorneys filed a class action suit against Avvo on a consumer protection theory, alleging that Avvo "purports to be objective when it is not, and is subject to manipulation." Mor Moover, the plaintiffs argued the site was inconsistent, inaccurate, and biased. ${ }^{62}$ The court granted Avvo's motion to dismiss, holding that the "opinions expressed through the rating system ... are absolutely protected by the First Amendment." "63 The court posited that the site did not deceive consumers because it "contains numerous reminders that the Avvo rating system is subjective," generating unfalsifiable opinions rather than facts that can be proven untrue. ${ }^{64}$

In past work I have critiqued the Avvo opinion's method of First Amendment analysis. ${ }^{65}$ If applied to general purpose search engines, it threatens to "Lochnerize" the field. Fortunately, more nuanced analysis has

58 Brandon Brown, Fortifying the Safe Harbors: Reevaluating the DMCA in a Web 2.0 World, 23 BERKELEY TECH. L.J. 437, 437 (2008) (defining Web 2.0 business models as websites that are based on and encourage user-generated content).

59 Compare the pressure to "claim" one's Avvo profile to young people's increasing need to monitor their Facebook pages. See Clive Thompson, Brave New World of Digital Intimacy, N.Y. TIMES, Sep. 7, 2008, at MM42 ("Ahan knows that she cannot simply walk away from her online life, because the people she knows online won't stop talking about her, or posting unflattering photos. She needs to stay on Facebook just to monitor what's being said about her.").

60 Josh Quittner, The Flickr Founders, TIME, Apr. 30, 2006, available at http://www.time.com/time/ magazine/article/0,9171,1186931,00.html ("Tom Sawyer got it right. Why paint a fence when you can get your friends to do it for you for free? He would have been the perfect new-media mogul. Spending time and money creating content on the Internet is so hopelessly dated, so dotcom, so very, very 1.0. The secret of today's successful Web 2.0 companies: build a place that attracts people by encouraging them to create the content-thereby drawing even more people in to create even more stuff.").

61 Class Action Complaint at 7 71, Browne v. Avvo, Inc., 525 F. Supp. 2d 1249 (W.D. Wash. 2007) (No. C07-0920RSL), 2007 WL 1752392.

62 See Avvo, 525 F. Supp. 2d at 1252.

63 Id. at 1251 .

64 Id. at 1252 .

65 See Oren Bracha \& Frank Pasquale, Federal Search Commission? Access, Fairness, and Accountability in the Law of Search, 93 CORNELL L. REV. 1149, 1189 (2008) (criticizing cases like Avvo for "extend[ing] First Amendment protection to new domains on the basis of vague or enigmatic rationales"); see also Frank Pasquale, Asterisk Revisited: Debating a Right of Reply on Search Results, $3 \mathrm{~J}$. BUS. \& TECH. L. 61, 72 (2008) (casting doubt on the degree to which organizers of information should be granted the First Amendment protection "to the extent that traditional content providers are protected"); DAWn Nunziato, VIRTUAL. FREEDOM: NET NEUTRALITY AND FREE SPEECH ONLINE 150 (2009) ("Congress can constitutionally regulate dominant search engine providers, not only to require that they provide access to ... content [from 'diverse and antagonistic sources'] but also to require that they provide meaningful access to such content."). 
informed the development of many physician rating sites, which have been pressured to act more responsibly by doctors and regulators. ${ }^{66}$ Physicians' efforts may set the tone for reputation regulation in employment, insurance, and credit generally. Their demands for open inspection of criteria and data used in doctor ratings produced by insurers helped inspire the proposals for qualified transparency developed below.

\section{B. Hidden Persuaders}

The role of the media in influencing politics is well known. ${ }^{67}$ Despite the power of carriers to influence the content their customers receive, their potential for bias has not come to the fore until relatively recently. In one notorious example, Verizon Wireless decided to block speech from the $\mathrm{Na}$ tional Abortion Rights Action League by refusing to carry the group's textmessage program on its network. ${ }^{68}$ Verizon reversed itself in this case only after a media firestorm, ${ }^{69}$ but it still keeps in place the policy that allows it to censor. ${ }^{70}$ While its direct blocking of a controversial group stirred media attention, subtler forms of degradation or slowing of disfavored content might evade general detection. ${ }^{71}$

${ }^{66}$ See, e.g., Office of the Att'y Gen. Healthcare Indus. Taskforce, State of N.Y. Office of the Att'y Gen., Doctor-Ranking Programs, http://www.oag.state.ny.us/bureaus/health_care/HIT2/doctor_ranking .html (last visited Mar. 11, 2010) ("In 2007, the [New York] Attorney General commenced an industrywide investigation into insurers' doctor-ranking programs. ... The [Office of the Attorney General] has settled with eight health insurance companies so far, instituting model reforms to ensure that any ranking programs are based on accurate and transparent measure[s]- and monitored for compliance.").

${ }^{67}$ See, e.g., C. EDWIN BAKER, MEDIA, MARKETS, AND DEMOCRACY (2002); C. Edwin Baker, Giving the Audience What It Wants, 58 OHIO ST. L.J. 311, 408 (1997) (describing the power of mass media to shape political consciousness and warning that "the increasing national and global concentration of media ownership into the hands of ... megamedia giants creates the danger that these few owners will guide development of political ... preferences along their preferred lines"). For example, Cumulus Media eliminated the Dixie Chicks from its playlists after the band criticized President Bush, and Sinclair Broadcast Group helped promote the "Swift Boat" controversy in the 2004 presidential race. Jerry Kang, Race.Net Neutrality, 6 J. ON TELECOMM. \& HiGH TECH. L. 1, 10 (2007); Jim Rutenberg, Broadcast Group to Pre-empt Programs for Anti-Kerry Film, N.Y. TIMES, Oct. 11, 2004, at A19, available at http:/www.nytimes.com/2004/10/1 1/politics/campaign/ 1 film.html?_r=1.

68 Adam Liptak, Verizon Blocks Messages of Abortion Rights Group, N.Y. TimES, Sept. 27, 2007, at Al ("Text messaging programs based on five- and six-digit short codes are a popular way to receive updates on news, sports, weather and entertainment.").

69 See Jack M. Balkin, Media Access: A Question of Design, 76 Geo. WASH. L. REV. 933, 933 (2008) (describing how Verizon eventually "backed down").

70 Jeffrey Rosen, Net Cemetery: Comcast, the Biggest Threat to Free Speech Since Nixon, NEW REPUBLIC, Oct. 12, 2009, at 10, available at http:/www.tnr.com/article/net-cemetery ("When activists objected to the decision, Verizon said it would block messages from all 'issues-oriented' groups, then later apologized for the whole mess, blaming the initial decision on a 'dusty internal policy.' Nevertheless, it kept the policy in place-reserving the right to censor any content 'that, in its discretion, may be seen as controversial or unsavory."').

${ }^{71}$ Felix Stalder, Analysis Without Analysis, MUTE, July 28, 2008, http://www.metamute.org/en/content/analysis_without_analysis ("There is a structural imbalance between the service providers who have a tangible incentive to expand their manipulative capacities and 
Given that most consumers have only one or two options, if any, for broadband connectivity, network providers can easily use their services to subtly advance their own political or cultural agendas without much fear of losing customers. ${ }^{72}$ Commenting on the FCC-regulated broadcasters, Jerry Kang notes that concentrated ownership "prompted the broadcast networks to remain silent about the digital TV spectrum that was given gratis to current television broadcast licensees, sans billions of dollars in auction payments." 73 Moreover, as C. Edwin Baker has argued, the market itself cannot be counted on to deliver socially optimal coverage of political news and current events. ${ }^{74}$

Carriers that aggressively monetize their networks may squeeze out disfavored content providers. Carriers are under increasing commercial pressure to develop revenue streams by leveraging their intermediary role. They may merge with content providers or just grant preferred access to their business partners. Application and content providers frozen out of such deals worry that they will face a pay-to-play regime in the absence of network neutrality rules. ${ }^{75}$ Many intermediaries both bring third parties' content to users and sell or monetize their own offerings. ${ }^{76}$ They have every

the average users, who will barely notice what's going on, since it would require a lot of effort to find out."). For a concrete example of the type of investigation required to detect problematic network management practices, see Daniel Roth, The Dark Lord of Broadband Tries to Fix Comcast's Image, WIRED, Jan. 19, 2009, at 54, available at http://www.wired.com/techbiz/people/magazine/1702/mf_brianroberts ("It took [a disgruntled Comcast customer] six weeks of short-burst sleuthing [to conclude that] Comcast appeared to be blocking file-sharing applications by creating fake data packets that interfered with trading sessions [because] [t]he packets were cleverly disguised to look as if they were coming from the user, not the ISP."). But see Steven Musil, Google Prepping BroadbandMonitoring Tools, CNET NEWS BLOG, http://news.cnet.com/8301-10784_3-9968972-7.html (June 15, 2008, 9:50 PDT) (reporting that Google is now developing tools to make this monitoring easier).

${ }^{72}$ Network Neutrality: Competition, Innovation, and Nondiscriminatory Access: Hearing Before the Taskforce on Telecom and Antitrust, H. Comm. on the Judiciary, 109th Cong. 45 (2006) (statement of Timothy Wu, Professor of Law, Columbia Law School) [hereinafter Wu Statement] (noting that "ninetyfour percent of Americans have either zero, one, or two choices for broadband access"). Admittedly, these figures are subject to contestation, in part because of one of the problems addressed in this article: trade secrecy protections for data submitted by companies to the FCC. See Benjamin W. Cramer, 'The Nation's Broadband Success Story': The Secrecy of FCC Broadband Infrastructure Statistics, 31 HASTINGS COMM. \& ENT L.J. 339, 340, 347 (2009) (discussing the lack of transparency "of the information that the FCC compiles before announcing its broadband deployment statistics-incoming data supplied by private telecommunications companies," and the "politicization of broadband deployment statistics").

${ }^{73}$ Kang, supra note 67, at 10.

${ }^{74}$ See C. Edwin Baker, Media Concentration: Giving Up on Democracy, 54 FlA. L. REV. 839, 87677 (2002) (documenting the negative effect of market pressures on political coverage).

${ }^{75}$ For example, the Future of Music Coalition worries that "a new form of Internet payola [will] emerge, with large Internet content providers striking business deals with the dominant Internet service providers." Jenny Toomey \& Michael Bracy, Op-Ed., Indie-Rock Revolution, Fueled by Net Neutrality, THE HILL, June 13, 2006, at 23.

${ }^{76}$ Several intermediaries are engaged in multiple businesses. For example: "Comcast is now the cable monopoly in $\mathbf{4 0}$ of the top 50 markets[,] . . the third largest phone company in the U.S., and the largest provider of broadband internet to homes, with nearly 15 million customers ...." Brooke Glad- 
incentive to privilege "content source partners" who share a cut of their profits or offer other consideration. ${ }^{77}$

From a purely economic perspective, it is difficult to criticize these developments. Vertical integration permits companies at different layers of the Internet to codevelop mutually beneficial product configurations. Perhaps big content providers' partnerships with carriers will lead them to maximize sales. Consumers may be happier if, instead of dealing with a fragmented entertainment landscape, they have more of a store of common. references. ${ }^{78}$ But we rightly object to a communications industry that can systematically disadvantage the work of content providers unwilling to engage in constraining business alliances or subtle payola. ${ }^{79}$ Moreover, letting a small group of corporate actors profit excessively from broadband provision would convert an infrastructural asset into a parasitic bottleneck.

The political consequences of untrammeled carrier power over networks are also disturbing. Bill D. Herman has catalogued a number of examples of content and application blocking. ${ }^{80}$ For example, during a bitter labor dispute, the Canadian carrier Telus blocked access to a union website, ${ }^{81}$ and AT\&T censored the rock group Pearl Jam's anti-Bush lyrics. ${ }^{82}$ Though media pressure led each company to pledge to reform its behavior in the future, ${ }^{83}$ no governmental institution has monitored such commitments closely.

Extant incidents involving carriers blocking access to content they disapprove of and applications that compete with their own proprietary services have attracted the attention of a vocal activist community. ${ }^{84}$ While

stone, The Die Is Cast (NPR On the Media radio interview broadcast Feb. 20, 2009), available at $\mathrm{http}: / / \mathrm{www}$.onthemedia.org/transcripts/2009/02/20/02. Perhaps in part to enhance demand for its own content offerings, Comcast temporarily blocked BitTorrent, a file sharing service. Id.

${ }^{77}$ Susan P. Crawford, Network Rules, 70 LAW \& CONTEMP. PROBS. 51, $64-65$ (2007) (discussing both technological and market pressures for vertical integration of content and conduit).

78 Gregg EasterbrooK, The Progress Paradox, at xv-xvi (2003) (discussing the correlation between increasing consumer choice and stagnant or declining perceptions of well-being in advanced industrial societies); BARRY SCHWARTZ, THE PARADOX OF CHOICE: WHY MORE IS LESS 20-24 (2004) (discussing cognitive psychology's documenting costs of excessive choice).

${ }^{79}$ Bill D. Herman, Opening Bottlenecks: On Behalf of Mandated Network Neutrality, 59 FED. COMM. L.J. 103, 119-23 (2006) (discussing instances of this kind of discrimination). Some telephone companies have scuttled service directed to competitors Vonage and Skype. Id. at 120 \& n.93.

80 See id. at 122.

81 Id.

82 Id: Nate Anderson, Pearl Jam Censored by AT\&T, Calls for a Neutral 'Net, ARS TECHNICA, Aug. 9, 2007, http://arstechnica.com/news.ars/post/20070809-pearl-jam-censored-by-att-calls-for-aneutral-net.html

${ }^{83}$ Gil Kaufman, AT\&T Admits It Edited Webcasts Before Pearl Jam's, MTV NEws, Aug. 13, 2007, http://www.mtv.com/news/articles/1566946/20070813/ pearl jam.jhtml ("'It's not our intent to edit political comments in webcasts ...' AT\&T spokeswoman Tiffany Nels said. ... 'Unfortunately, it has happened in the past in a handful of cases. We have taken steps to ensure it won't happen again."').

84 See, e.g., Tim Karr, Seven Reasons: Why We Need Net Neutrality Now, SAVETHEINTERNET.COM, Aug. 3, 2009, http://www.savetheinternet.com/blog/09/08/03/seven- 
carriers try to trivialize each incident individually, the pattern suggests a willingness to tilt the digital playing field. ${ }^{85}$ Public interest groups like Free Press and Public Knowledge have organized protests against discriminatory treatment of content online. ${ }^{86}$

Public interest groups are now beginning to focus on the power of search engines to organize the web. ${ }^{87} \mathrm{~A}$ critical media studies literature has spurred this movement by chronicling how the "politics of search engines matters."

reasons-why-we-need-net-neutrality-now (discussing the timeliness and necessity of the introduction of the Internet Freedom Preservation Act of 2009); Eric Schmidt, A Note to Google Users on Net Neutrali$t y$, GOOGLE, http://www.google.com/help/netneutrality_letter.html (last visited Mar. 11, 2010) (requesting Internet users to contact their congressional representative regarding a bill in favor of net neutrality introduced in the House of Representatives).

${ }^{85}$ Peter Glaskowsky, Net Neutrality-Dead or Simply Hibernating?, CNET NEws, Sept. 7, 2007, http://news.cnet.com/8301-10784_3-9773691-7.html ("The net neutrality controversy really flared up, as [fellow CNet journalist Declan] $\overline{M c C u l l a g h}$ says, 'after AT\&T CEO Edward Whitacre was quoted as talking about (no longer) giving Google and other Internet companies a 'free ride' on his network, whatever that means."' (quoting Declan McCullagh, Ten Things that Finally Killed Net Neutrality, CNET NEWS, Sept. 6, 2007, http://news.cnet.com/8301-13578_3-9773538.html?tag=mncol;txt)); see also Kaufman, supra note 83 .

${ }^{86}$ Public Knowledge and Free Press are public interest groups that advocate for consumer rights online. They have lobbied against expansive intellectual property rules, broadband discrimination, and excessive corporate influence in the shaping of FCC policy. Cecilia Kang, Net Neutrality's Quiet Crusader: Free Press's Ben Scott Faces Down Titans, Regulators in Battle over Internet Control, WASH. POST, Mar. 28, 2008, at D01, available at http://www.washingtonpost.com/wpdyn/content/article/2008/03/27/AR2008032703618.html (noting that members of the public-interest group Free Press went to an FCC hearing to push for new rules for the Internet as well as that the purpose of the hearing was to discuss Web regulations and policies that would determine how much control cable and telecommunication companies have over the Internet).

${ }^{87}$ Miguel Helft, Opposition to Google Books Settlement Jells, N.Y. TIMES BITS BLOG, http://bits.blogs.nytimes.com/2009/04/17/opposition-to-google-books-settlement (Apr. 17, 2009, 16:34 EST) ("Various groups, including the Internet Archive and Consumer Watchdog, have raised their concerns with lawyers at the Justice Department."); Fred von Lohmann, Google Book Search Settlement: A Reader's Guide, ELEC. FRONTIER FOUND. DEEPLINKS BLOG, http://www.eff.org/deeplinks/2008/10/ google-books-settlement-readers-guide (Oct. 31, 2008) ("This is a huge change in the privacy we traditionally enjoy in libraries and bookstores . . . "); EPIC, supra note 17 ("On April 20, 2007, EPIC, the [Center for Digital Democracy], and [U.S. Public Interest Research Group] filed a complaint with the Federal Trade Commission, requesting that the Commission open an investigation into the proposed acquisition ...."); Marc Rotenberg, President of the Electronic Privacy Information Center, Data Protection and Search Engines on the Internet: Google-DoubleClick and Other Case Studies, Address Before the European Parliament and LIBE Committee (Jan. 21, 2008), available at http://epic.org/privacy/ftc/ google/EPIC_LIBE_Submission.pdf (discussing the privacy concerns raised by the merger of Google and DoubleClick); Letter from Jamie Court \& John Simpson, Consumer Watchdog, to Eric Schmidt, Chief Executive Officer, Google (Oct. 13, 2008), http:/www.consumerwatchdog.org/resources/CWLet terToGoogle 10-13-08.pdf (expressing concern that, among other things, Google Chrome's implementation of Google Suggest and Incognito features do not properly protect user privacy).

88 Siva VaidHYANATHAN, THE Googlization OF EVERYTHING (forthcoming 2010); see also Alejandro M. Diaz, Through the Google Goggles: Sociopolitical Bias in Search Engine Design, in WEB SEARCH 11, 28 (Amanda Spink \& Michael Zimmer eds., 2008) (describing how the complexity and opacity of search engine technology makes it "hard to see what's 'missing' from search results ... [and] users are unlikely to even consider a switch"); Lucas D. Introna \& Helen Nissenbaum, Shaping the Web: 
search engines effectively create winners and losers on the web as a whole. Now that search engines are moving into other realms, this often opaque technology of ranking becomes kingmaker in new venues." ${ }^{\text {89 }}$ The power of dominant intermediaries emerges naturally from struggles for prominence online: "[T] he natural tendency of the web is to link very heavily to a small number of sites," resulting in ranked results that predictably "pick[] winners." ${ }^{\circ 0}$ If, as Clifford Geertz memorably observed, "man is an animal suspended in webs of significance he himself has spun," dominant search engines are a key platform where these webs are woven on the internet. ${ }^{91}$ Heated disputes are emerging regarding the duties that should constrain this process and the norms that should guide it.

Consider some Republicans' fears that Google, a culturally liberal company ${ }^{92}$ is skewing search results to favor Barack Obama and marginalize the right. ${ }^{93}$ Fox News has reported conservative discontent at Google's rapid response to manipulated search results related to Barack Obama after its glacial efforts to defuse a "google bomb" aimed at George W. Bush (in which Bush's biography would appear when the words "miserable failure"

Why the Politics of Search Engines Matter, 16 INFO. SOC'Y 169, 177 (2000) ("The rich and powerful clearly can influence the tendencies of search engines; their dollars can (and in a restricted way do already) play a decisive a role in what gets 'found."').

89 ALEX HaLAVAis, SEARCH ENGINE SOCIETY 85 (2009); see also Adam Raff, Search, but You May Not Find, N.Y. TIMES, Dec. 27, 2009, at A27, available at http://www.nytimes.com/2009/12/28/opinion/ 28raff.html?_r=1 ("With 71 percent of the United States search market (and 90 percent in Britain), Google's dominance of both search and search advertising gives it overwhelming control.... One way that Google exploits this control is by imposing covert 'penalties' that can strike legitimate and useful Web sites, removing them entirely from its search results or placing them so far down the rankings that they will in all likelihood never be found. For three years, my company's vertical search and pricecomparison site, Foundem, was effectively 'disappeared' from the Internet in this way.").

90 HALAVAIS, supra note 89 , at 60.

91 ClifFord GeERTZ, THE INTERPRETATION OF Cultures: SElected EsSAYS 5 (2000 ed.) (1973). For a compelling example of search engines' influence on worldviews, compare the searches for 'Tiananmen Square" images presented in James Grimmelmann's work. See James Grimmelmann, The Google Dilemma, 53 N.Y.L. SCH. L. REV. 939, 948 (2008-09) (presenting images of tanks from Google.com and images of the Gate of Heavenly Peace from Google.cn). Google has announced that it may stop cooperating with Chinese government requests for censorship. See Posting of David Drummond to Official Google Blog, A New Approach to China, http://googleblog.blogspot.com/2010/01/ new-approach-to-china.html (Jan. 12, 2010, 15:00 EST) ("We have decided we are no longer willing to continue censoring our results on Google.cn, and so over the next few weeks we will be discussing with the Chinese government the basis on which we could operate an unfiltered search engine within the law, if at all.").

${ }^{92}$ See, e.g., Mary Anne Ostrom, Google CEO Eric Schmidt to Stump for Obama, SAN JOSE MERCURY NEWS, Oct. 20,2008, available at http://www.mercurynews.com/ci_10769458 (noting that Google's CEO openly supported Obama); Posting of Sergey Brin to Offical Google Blog, Our Position on California's No on 8 Campaign, http://googleblog.blogspot.com/2008/09/our-position-on-califomiasno-on-8.html (Sept. 26, 2008, 15:23 EST) (describing the company's opposition to proposed ban on same-sex marriage).

93 See Google News: Not So Fair and Balanced, Michelle Malkin Blog, http://michellemalkin.com/2005/02/05/google-news-not-so-fair-and-balanced (Feb. 5, 2005, 18:49 EST) (accusing Google of anticonservative bias in its selection of sources for inclusion in Google News). 
were searched). ${ }^{94}$ Although it took Google four years to address the issue with respect to President Bush, when President Obama faced similar online satire, "Google stepped in quickly, rectifying the situation in a few days." 95 There are many good reasons for the difference in treatment. ${ }^{96}$ Google may have learned from the Bush experience and may now be capable of far faster responses to pranks. ${ }^{97}$ Or the company's engineers may dismiss such manipulation as a silly prank that really should not waste their time. Nevertheless, political manipulation of Google merits some attention. Campaigns are a struggle for salience, competitions with considerable stakes. ${ }^{98}$ As more people form impressions of candidates from search results (or related Google properties like YouTube), we might worry that allegedly neutral, algorithmic representations of authority and popularity are really being influenced by a hidden agenda.

Part II explains why Internet policy that is based primarily on the promotion of competition and innovation is unlikely to prevent any of the problems mentioned above. Part III shows how market-based approaches to Internet policymaking can exacerbate the trends toward unaccountable intermediaries documented above. Part IV proposes monitoring and disclosure designed to assure some accountability for search engines and other key intermediaries.

\section{COMPETITION AND INNOVATION AS FOUNDATIONS OF INTERNET POLICY}

Innovation has been the central focus of Internet law and policy. ${ }^{99}$ While leading commentators sharply divide on the best way to promote innovation, they routinely elevate its importance. Business writers have celebrated search engines, social networks, and other startups as model

94 See Joshua Rhett Miller, Unlike Bush's 'Google Bomb,' Google Quickly Defuses Obama's, FOXNEwS.COM, Jan. 30, 2009, http://www.foxnews.com/story/0,2933,485632,00.html (describing Google's failure to change its algorithm to avoid a gamed result that led users searching "miserable failure" to President Bush's biography).

95 Id. ("The difference in time did not go unnoticed.").

${ }^{96} \mathrm{Id}$.

97 Id.

98 For more on the "struggle for salience" model of campaigning, see Frank Pasquale, Reclaiming Egalitarianism in the Political Theory of Campaign Finance Reform, 2008 U. ILL. L. REV. 599, 644 ("Utilizing statistical evidence from several campaigns, John Petrocik concludes that, to candidates, "the campaign [is] a marketing effort in which the goal is to achieve a strategic advantage by making problems that reflect owned issues the criteria by which voters make their choice."').

99 Gaia Bernstein, In the Shadow of Innovation, 31 CARDOZO L. REV. (forthcoming 2010) (manuscript at 5), available at http://papers.ssrn.com/sol3/papers.cfm?abstract_id=1395779 (observing that, in technology policy, "all parties raise innovation arguments to justify their positions"); see also, e.g., GARY REBACK, FREE THE MARKET!: WHY ONLY GOVERNMENT CAN KEEP THE MARKETPLACE COMPETITIVE 374 (2009) ("To maintain the country's high standard of living in the coming decades, antitrust policy must renew its commitment to competition, the font of economic growth. Competition engenders innovation, and innovation will keep our country ahead in world markets."). 
corporations in a new service economy. ${ }^{100}$ Academics have also promoted their growth. For example, Lawrence Lessig has proposed eliminating the FCC and replacing it with a streamlined entity with one goal and one way to achieve it: promoting innovation and reducing the type of monopoly power that can stand in its way. ${ }^{101}$ Innovation is the goal; competition is the means for achieving it.

Lessig and other advocates of network neutrality worry that the owners of the "pipes" that carry communications may impede that innovation by favoring their own applications. ${ }^{102}$ YouTube might never have developed if Verizon could have throttled it in favor of its own video sharing site; online innovation in general would be discouraged if carriers consistently charged innovators more for access to customers as they became more successful. The drama of "good innovators" versus "bad carriers" has pervaded net neutrality advocacy.

Laissez-faire voices have disputed this vision, ${ }^{103}$ contending that the key competition Google or YouTube might face in the future is a search engine or video-sharing service given a leg up by carriers. ${ }^{104}$ On this view, there is nothing special about the physical layer of Internet communications that makes it uniquely dangerous for innovation. ${ }^{105}$ Advantage at the physi-

100 See, e.g., JEFF JARVIS, WHAT WOULD GOOGLE DO? (2009) (popular business book advising companies to adopt Google's practices; title puns on the Christian Evangelical motto "What Would Jesus Do"); Bala Iyer \& Thomas H. Davenport, Reverse Engineering Google's Innovation Machine, HARV. BUS. REV., Apr. 1, 2008, at 59 ("In the pantheon of Internet-based companies, Google stands out as both particularly successful and particularly innovative.").

101 Lawrence Lessig, Reboot the FCC, NEwswEek, Dec. 23, 2008, at 45 ("President Obama should get Congress to shut down the FCC and similar vestigial regulators, which put stability and special interests above the public good. In their place, Congress should create something we could call the Innovation Environment Protection Agency (iEPA), charged with a simple founding mission: 'minimal intervention to maximize innovation.' The iEPA's core purpose would be to protect innovation from its two historical enemies-excessive government favors, and excessive private monopoly power.").

102 LAWRENCE LESSIG, THE FUTURE OF IDEAS: THE FATE OF THE COMMONS IN A CONNECTED WORLD 46-48, 155-76, 246-49 (2001); Susan P. Crawford, The Internet and the Project of Communications Law, 55 UCLA L. REV. 359, 395-98 (2007) [hereinafter, Crawford, Internet] ("By 'discrimination' I mean allowing network-access providers to treat some traffic or some users differently.").

103 See, e.g., Alfred E. Kahn, Telecommunications: The Transition from Regulation to Antitrust, $5 \mathrm{~J}$. TELECOMM. \& HIGH TECH. L. 159, 182-84 (2006) (arguing that many forms of regulation of telecommunication companies are "in essential conflict with and obstructive of the developing dynamic competition among technologically different platforms"); Christopher S. Yoo, Would Mandating Broadband Network Neutrality Help or Hurt Competition? A Comment on the End-to-End Debate, 3 J. ON TELECOMM. \& High TECH. L. 23, 65 (2004) [hereinafter Yoo, Comment] (objecting to net neutrality advocates' preference for homogeneous, "dumb" pipes, and concluding that differentiation may provide for economic benefits by allowing networks to better satisfy heterogeneous customer preferences).

104 Arpan Sura, The Problems with Network Neutrality, INFO TECH \& TELECOM NEws, May 1, 2006, http://www.heartland.org/policybot/results/18903/The_Problems_with_Network_Neutrality.html ("If a company wants to favor video or voice content, it can find consumers and applications providers who use the Internet primarily for this purpose.").

${ }^{105}$ For the distinction between layers on the Internet, see ZITTRAIN, supra note 30, at 67 (describing a physical layer, an application layer, a content layer, and a social layer). 
cal layer may be the only way a newcomer can challenge entrenched intermediaries at the content or applications layers. This "clash of the titans" approach defends combinations of firms and the rejection of regulatory impediments to vertical integration. ${ }^{106}$

Technological change and new business realities are now radically challenging both extant interventionism and "market knows best" approaches. Rather than developing alternatives to dominant search engines and social networks, carriers are partnering with them and combining forces to create new communication technologies. The old narrative of "carrier versus search engine" is giving way to new forms of cooperation that will magnify the effects of bias by the collaborating entities. For example, Google has coinvested with Comcast and handset manufacturers to develop a new "Clearwire" 107 network. ${ }^{108}$ In return for its participation, "Google's search engine [will] get[] its own button on the phones." 109 It is hard to imagine a more effective "fast tracking" of one application provider's site past others. As the landscape of Internet competition rapidly shifts, dominant search engines like Google may become less a countervailing force keeping carriers accountable and more a beneficiary of the very discriminatory tactics they once decried. As such deals advance, disclosure of their terms is essential to ensure that users know the incentives motivating the carriers and search engines they use. ${ }^{110}$

106 Christopher S. Yoo, Beyond Network Neutrality, 19 HARV. J.L. \& TECH 1, 15-20 (2005) [hereinafter Yoo, Beyond Neutrality]; Christopher S. Yoo, Vertical Integration and Media Regulation in the New Economy, 19 YALE J. ON REG. 171, 295 (2002) ("[T]o the extent that anti-competitive dangers exist, they are better addressed in a forum, such as an antitrust court, that can evaluate each situation on the basis of its individual facts.").

107 Clearwire is a high-speed Internet and phone service provider. See Clearwire, https:/www.clearwire.com/internet-phone-service/overview.php (last visited Mar. 12, 2010).

108 Posting of Tom Steinert-Threlkeld to ZDNet Between the Lines Blog, Net Neutrality \& Google's Openness Before the FCC, http://blogs.zdnet.com/BTL/?p=9487 (July 30, 2008, 9:37 EST) ("Google says the network is open and Clearwire will only 'engage in reasonable and competitivelyneutral network management.' But, from a practical standpoint, is it 'competitively-neutral' if the managers of the network favor one of their partners to be the door that customers open to enter the Internet?"); $c f$. ROBERT W. MCCHESNEY, RICH MEDIA, POOR DEMOCRACY 160-64 (2000) (chronicling convergence deals in the late 1990 s and the cultural concerns they raised).

109 Thomas Hazlett, On a Clearwire, You Can See Everything, Fin. TIMES, July 23, 2008, http://www.ft.com/cms/s/0/dac15122-58cc-11dd-a093-000077b07658.html?nclick_check=1. As Hazlett puts it, if this "model, where the carrier extracts payment from mobile apps for a preferred spot on the wireless web, is 'open'-then 'open' all capitalists must be." Id.

110 At a hearing on the proposed Google-Yahoo! joint venture, House Judiciary Chairman John Conyers complained that neither he nor other committee members were allowed to inspect the terms of the deal in a practicable manner. See Competition on the Internet: Hearing Before the Task Force on Competition Policy and Antitrust Laws of the H. Comm. on the Judiciary, 110th Cong. 48 (2008) (statement of Rep. John Conyers, Chairman, H. Comm. on the Judiciary), available at http://judiciary.house. gov/hearings/printers/110th/43524.pdf at 2 [hereinafter Hearing] (complaining that the members of the Committee were only permitted to inspect the deal if they viewed its terms "at a law firm with no notes allowed"). Chairman Conyers further stated that "the Committee was given more ready access to the documents surrounding the President's terrorist surveillance program" than it was to the terms of the 
As Internet traffic increases, carriers are likely to face the same dilemmas of information overload now managed by search engines. ${ }^{111}$ Their vertical integration with content providers is developing, and alliances with powerful social networks are also possible. While network neutrality advocates focus on the convergence of voice, data, and content on common physical infrastructure, ${ }^{112}$ the joint ventures of leading Internet companies will raise a new host of concerns about privacy, culture, and power online. Calls for network neutrality are already morphing into demands for transparency and fairness from dominant intermediaries generally, be they search engines, social networks, or carriers. ${ }^{113}$

Deregulationists believe that the market will punish any untoward behavior by intermediaries. ${ }^{114}$ They claim that undue discrimination or invasive surveillance will cost an entity customers-and to the extent monopoly

proposed (and ultimately aborted) Google-Yahoo! joint venture. Id. (Video clip available at http://www.c-spanarchives.org/library/index.php?main_page=product_video_info\&prod ucts_id =206402-1 \&showVid=true\&clipStart=285.86\& clipStop=368.60).

111 For a sense of the dynamics of information overload here, see Ohm, supra note 36, at 1438 ("To better understand why the relative slowness of computers has constrained ISP surveillance, picture network monitoring like a police officer on the side of a road, scanning the passing traffic for drivers swerving or speeding or for cars with outdated license plates. How thoroughly the officer inspects the passing traffic depends on two metrics: the volume of traffic-the number of cars that pass by each hour-and the efficiency of the officer-how quickly he can inspect a single car. On the Internet, computers running monitoring tools are like the police officer and the rate of the network traffic flowing past the computer - the flow rate or bandwidth-is like the volume of cars passing on the highway.").

112 Lawrence Lessig \& Robert W. McChesney, No Tolls on the Internet, WASH. POST, June 8, 2006, at A23, available at http://www.washingtonpost.com/wp-dyn/content/article/2006/06/07/AR200606070 2108.html.

113 NUNZLATO, supra note 65, at 111-14 (discussing Google's apparent censorship of several groups in its advertising and news services). Nunziato argues that both carriers and search engines can distort the communicative environment online in troubling ways. Id.; see also Richard Waters, Net Neutrality Comes Back to Haunt Google, Fin. TIMES, July 13, 2010 ("This year, 'search neutrality' has become the rallying cry of activists who believe that Google has too much power to decide which internet sites are granted the attention that comes with a high search ranking, and which are consigned to outer darkness."); Nate Anderson, After Net Neutrality, Will We Need "Google Neutrality?", ARs TECHNICA, Oct. 29, 2009, http://arstechnica.com/tech-policy/news/2009/10/after-net-neutrality-will-we-need-googleneutrality.ars ("[A]s cloud computing takes off, one company (again, this might well be Google) could so completely dominate the market that it becomes another choke point. We might then need to consider 'cloud neutrality."'); Kelly Hearn, Google's Bias for Bigness, ALTERNET, http://www.alternet.org/ story/23397/ ("Google doesn't comment on its present or future ranking criteria . . . . But for alternative online news services ... that rely on Google News-related traffic, the company's patent application offers reason to worry about just how shallow a pool of sources the site will draw from.").

114 See, e.g., J. Gregory Sidak, Telecommunications in Jericho, 81 CAL. L. REV. 1209, 1213 (1993) (reviewing and praising MiCHAEL K. KellogG ET AL., Federal TeleCOMMUNiCATIONS LAW (1992), for promoting the idea that "advancing technology renders obsolete and arbitrary, if not also unlawful or unconstitutional, the regulatory boundaries that currently divide various telecommunications firms and circumscribe the services that they may provide"); see also Kahn, supra note 103; Yoo, Comment, supra note 103 . 
power prevents that loss of business, antitrust law is remedy enough. ${ }^{115}$ Were new concerns about intermediaries wholly economic in nature, such assurances might justify a laissez-faire approach. However, the cultural, political, and privacy concerns raised by the new business alliances of search engines, social networks, and carriers cannot be translated into traditional economic analysis. They raise questions about the type of society we want to live in-a holistic inquiry that cannot be reduced to the methodological individualism of economics.

This Part critically examines the legal academy's focus on purely economic dimensions of carrier and search engine policy. ${ }^{116}$ Section A demonstrates the inadequacies of the primarily economic debate on broadband policy that has focused on innovation economics, while Section B questions competition as a prime policy goal for the search industry.

\section{A. Net Neutrality as Innovation Policy}

Both scholars and activists have promoted "network neutrality" rules that would limit carriers' control over users' experience of the Internet. ${ }^{117}$ To bring the topic down to earth, these scholars tend to model Internet communications as a form of transport of information, which should be subject to common carriage rules. ${ }^{118}$ However, as the section below demonstrates, this metaphor and the underlying substantive policy may raise as many questions about broadband governance as it answers.

Net neutrality advocacy has focused on carrier control as a threat to innovation. ${ }^{119}$ After weighing the potential harms and benefits of broadband

115 See Christopher S. Yoo, What Can Antitrust Contribute to the Network Neutrality Debate?, 1 INT'L J. COMM. 493, 511-17 (2007); see also Yoo, Beyond Neutrality, supra note 106, at 8 ("Economic theory suggests that network neutrality proponents are focusing on the wrong policy problem. One of the basic tenets of vertical integration theory is that any chain of production will only be as efficient as its least competitive link."). Yoo also worries about regulation stifling efficiencies and innovation. See Yoo, Comment, supra note 103, at 55-59 ("Simply put, allowing network owners to employ different protocols can foster innovation by allowing a wider range of network products to exist. Conversely, compulsory standardization can reduce consumer surplus by limiting the variety of products available.").

116 I am attempting to bring an awareness of the limits of economics long present in media studies to legal scholarship on intermediaries. See, e.g., Robert Entman \& Steven S. Wildman, Reconciling Economic and Non-Economic Perspectives on Media Policy: Transcending the "Marketplace of Ideas", 42 J. COMM. 5 (1992).

${ }^{117}$ See, e.g., Lessig, supra note 101 ("Congress should create something we could call the Innovation Environment Protection Agency (iEPA), charged with a simple founding mission: 'minimal intervention to maximize innovation.' The iEPA's core purpose would be to protect innovation from its two historical enemies-excessive government favors, and excessive private monopoly power.").

118 See, e.g., Susan P. Crawford, Transporting Communications, 89 B.U. L. REV. 871, 877-83 (2009) (tracing "the tangled history of the legal notion of 'common carriage' in this country"); Wu, supra note 102 , at $165-68$ (laying out a network neutrality proposal that would allow for local network restrictions but treat internetwork restrictions as suspect).

119 See, e.g., Lessig \& McChesney, supra note 112 ("How will this innovation and production thrive if creators must seek permission from a cartel of network owners?"). 
providers' discrimination, Barbara van Schewick has argued that "increasing the amount of application-level innovation through network neutrality regulation is more important than the costs associated with it." 120 Along with Brett Frischmann and Spencer Weber Waller, ${ }^{121}$ Susan Crawford, ${ }^{122}$ and Timothy $\mathrm{Wu},{ }^{123}$ she suggests that network operators unconstrained by such rules would inevitably be tempted to elevate the salience and availability of partners' applications and content and thus block or degrade access to competitors' applications. ${ }^{124}$ For this reason, Frischmann has argued that networks constitute infrastructure analogous to roads, bridges, and public transit. ${ }^{125}$ Although managers of transportation networks can reasonably charge more to certain customers at certain times to manage congestion or perform repairs, it would be deeply unfair for the manager of a highway to ban Volkswagen vehicles because it struck a special deal with General Motors. These concerns lead Sascha Meinrath and Victor Pickard to propose an array of conditions on broadband networks in order to make them neutral among business models. ${ }^{126}$

While the FCC has proven somewhat receptive to these ideas, ${ }^{127}$ the FTC and the Antitrust Division of the U.S. Department of Justice (DOJ) re-

120 Barbara van Schewick, Towards an Economic Framework for Network Neutrality Regulation, 5 J. Telecomm. \& High TeCH. L. 329, 329 (2007). Van Schewick also applies "insights from game theory, industrial organization, antitrust, evolutionary economics and management strategy to analyze network operators' incentives to discriminate, the impact of potential discriminatory behavior on innovation and social welfare, and the costs of regulation." Id. at 332.

121 Brett Frischmann \& Spencer Weber Waller, Revitalizing Essential Facilities, 75 ANTITRUST L.J. 1,2 (2008) ("Communications networks have traditionally been conceptualized as infrastructure subject to substantial access and nondiscrimination norms and, as a result, have been heavily regulated.").

122 Susan P. Crawford, The Radio and the Internet, 23 BERKELEY TECH. L.J. 933, 960-61 (2008); Susan Crawford Blog, FAQ on Net Neutrality, http://scrawford.blogware.com/blog/_archives/2006/5/31/ 1998151.html (May 31, 2006, 23:57 EST).

$123 \mathrm{Wu}$, supra note 102 , at 144, 165-72 (showing "what a workable principle of network neutrality would look like and what it would mean for the conduct of broadband providers").

124 See van Schewick, supra note 120, at 342-45.

125 Brett M. Frischmann, An Economic Theory of Infrastructure and Commons Management, 89 MINN. L. REV. 917, 923-33 (2005). Frischmann argues, "[F]or some classes of important resources, there are strong economic arguments for managing and sustaining the resources in an openly accessible manner." Id. at 918-19.

126 Sascha D. Meinrath \& Victor W. Pickard, Transcending Net Neutrality: Ten Steps Toward an Open Internet, J. INTERNET L., Dec. 2008, at 1, 18 (endorsing a network that "1. Requires common carriage; 2. Supports open architecture and open source driver development; 3. Maintains open protocols and open standards; 4. Facilitates an end-to-end architecture (i.e., is based upon a 'dumb network'); 5. Safeguards privacy (e.g., no back doors, deep packet inspection, etc.); 6. Fosters application-neutrality; 7. Mandates low-latency and first-in/first-out (i.e., requires adequate capacity); 8. Ensures interoperability; 9 . Remains business-model neutral; 10 . Is governed by its users (i.e., is internationally representative and non-Amerocentric)").

127 Even during the Bush Administration, the FCC was willing to challenge particular actions that violated principles of net neutrality. See, e.g., FCC Comcast Decision, supra note 5, ๆף 32, 41 ("[B]ecause Comcast's method, sending RST packets to both sides of a TCP connection, is the same method computers connected via TCP use to communicate with each other, a customer has no way of 
jected network neutrality regulation under the Bush Administration. ${ }^{128}$ Bush's Antitrust Division claimed that such regulation should not be imposed on broadband providers until abusive practices have been thoroughly documented. ${ }^{129}$ It believed that the broadband market is increasingly competitive in that it gives consumers an exit option, even if they lack a voice in network management. ${ }^{130}$ Bush's DOJ accepted the general laissez-faire position that network operators will maximize the social utility of networks if they can privately profit from the expansion of services on them. ${ }^{131}$

Opposition to network neutrality has also taken hold in some fields of communications law. Some legal scholars analogize the carriage of bits to other transportation networks that can be congested, including the U.S. mail

knowing when Comcast (rather than its peer) terminates a connection. ... [W]e think a case-by-case, adjudicatory approach [to investigating such conduct] comports with congressional directives and Commission precedents"). The Obama Administration's FCC Chairman is more of an advocate for net neutrality rules than his predecessor, Kevin Martin. See Julius Genachowski, Chairman, FCC, Preserving A Free and Open Internet: A Platform for Innovation, Opportunity, and Prosperity, Remarks at the Brookings Institution (Sept. 21, 2009), available at http://openinternet.gov/read-speech.html ("Congress and the President have charged the FCC with developing a National Broadband Plan to ensure that every American has access to open and robust broadband.").

${ }^{128}$ See Ex Parte Filing of U.S. Dep't of Justice at 1, In re Broadband Industry Practices, No. 07-52 (Fed. Commc'n Comm'n Sept. 6, 2007), available at http:/www.usdoj.gov/att/public/comments/225767 .pdf (asserting that free market competition, "enforced by antitrust laws," is the best way to foster innovation and the development of the Internet) [hereinafter DOJ Ex Parte Filing]; BROADBAND CONNECTIVITY COMPETITION POLICY, FTC STAFF REPORT 157-61 (June 2007), http://www.ftc.gov/reports/broadband/v070000report.pdf (announcing FTC's caution regarding regulatory moves here).

${ }^{129}$ DOJ Ex Parte Filing, supra note 128, at 5 ('“[D]espite the Commission's request for evidence of harmful discrimination or behavior, as discussed further below, commenters failed to present evidence suggesting that a problem exists."). The DOJ here followed a long line of laissez-faire analysts who have argued that preemptive regulation is unnecessary. See, e.g., Kahn, supra note 103, at 183 (asserting that the broadband market is not suited for public utility-style regulation); Sidak, supra note 114, at 1209 ("American telecommunications regulation is about to collapse like the walls of Jericho.").

${ }^{130}$ See DOJ Ex Parte Filing, supra note 128, at 7 ("The Commission's statistics report that the total number of broadband fiber lines increased from 40,627 in 2000 to 698,990 as of June 30,2006 , and the number of residential broadband fiber lines likewise increased from 325 in 2000 to 442,027 fiber lines as of June 30, 2006."). But see Wu Statement, supra note 72, at 55 ("Ninety-four percent of Americans have either zero, one, or two choices for broadband access.").

131 See DOJ Ex Parte Filing, supra note 128, at 4 ("Precluding broadband providers from charging fees for priority service could shift the entire burden of implementing costly network expansions and improvements onto consumers. Because the average consumer may be unwilling or unable to pay significantly more for access to the Internet in order to ensure smooth delivery to consumers demanding bandwidth-intensive and latency-sensitive content, critical network expansion and improvement may be significantly reduced or delayed."); see also Tim Wu \& Christopher Yoo, Keeping the Internet Neutral?: Tim Wu and Christopher Yoo Debate, 59 FED. COMM. L.J. 575, 577 (2007) ("At this point, it is impossible to foresee which architecture will ultimately represent the best approach. When it is impossible to tell whether a practice would promote or hinder competition, the accepted policy response is to permit the practice to go forward until actual harm to consumers can be proven. This restraint provides the room for experimentation upon which the normal competitive processes depend."). 
delivery system. ${ }^{132}$ The U.S. Postal Service lets customers purchase priority mail delivery, and private carriers such as FedEx provide this and other forms of service. Network-neutrality opponents similarly point to airlines that cross-subsidize rural routes by selling very high-priced business seats and using those revenues to make up for seats sold for below average cost on the rest of the plane. ${ }^{133}$ Network operators argue that a "fast lane" of access is necessary to fund infrastructural improvements that (may eventually) redound to everyone's benefit. ${ }^{134}$ From this perspective, price discrimination is the best way to ensure efficient allocation of Internet resources. ${ }^{135}$ These arguments play the "wrong metaphor" card-the insistence that economic theory supporting net neutrality incorrectly analogizes Internet communications networks to traditional common carriers. ${ }^{136}$

Network neutrality supporters contend that a division of access into slow and fast lanes would lead to more invasive and counterproductive

132 Wu \& Yoo, supra note 131, at 578-79 (Yoo argues that the same logic of having "tiered" postal services like FedEx can be applied to having "tiered access" on the Internet); Christopher S. Yoo, Network Neutrality and the Economics of Congestion, 94 GEO. L.J. 1847, 1879 (2006) ("As an initial matter, the Internet is subject to congestion in a way that was not true with respect to conventional telephone service. ... [T] [Te attachment of devices used to run bandwidth-intensive applications to the network can adversely affect the quality of service enjoyed by other end users, and these devices arguably represent situations in which restrictions on attaching devices would be permissible under both Carterfone [In re Use of the Carterfone Device in Message Toll Tel. Serv., 13 F.C.C.2d 420 (1968)] and Husha-Phone [Hush-a-Phone Corp. v. United States, 238 F.2d 266 (D.C. Cir. 1956)]."). But see Philip J. Weiser, The Next Frontier for Network Neutrality, 60 ADMIN. L. REV. 273, 284-85 (2008) ("[Some] claim that robust competition in the broadband marketplace will prevent firms from acting in an anticompetitive fashion. ... [t] the reality, however, is that the search for the third broadband pipe-i.e., an alternative to cable modem and DSL connections - is ongoing, and the broadband access marketplace is largely a duopoly. In this respect, the broadband market differs from that of, for example, overnight delivery both in that U.S. post office 'best effort' delivery is regulated and there is considerable competition in the overnight delivery market (there are at least four facilities-based providers).").

${ }^{133}$ See Robert W. Hahn \& Robert E. Litan, The Myth of Network Neutrality and What We Should Do About It 10-11 (AEI-Brookings Joint Center, Working Paper No. RP06-33, 2006), available at http://ssm.com/abstract $=947847$.

134 See C. Scott Hemphill, Network Neutrality and the False Promise of Zero-Price Regulation, 25 Y ALE J. ON REG. 135, 172 (2008) ("In particular, access providers could subsidize consumer adoption by charging content providers for access. AT\&T's pitch might be: 'We're committed to pervasive broadband service, and to making access available to the millions who lack such service, by asking successful content providers to tithe a fraction of their profits, to be applied toward the provision of new consumer access." (footnotes omitted)).

135 See Yoo, Comment, supra note 103, at 59-65 (arguing that allowing last-mile providers to use vertical integration to differentiate their networks would allow the realization of certain efficiencies and would permit them to offer a broader range of services).

${ }^{136}$ See David W. Opderbeck, Deconstructing Jefferson's Candle: Towards a Critical Realist Approach to Cultural Environmentalism and Information Policy, 49 JURIMETRICS J. 203, 217-18 (2009) (discussing the arguments of the Telecommunications Industry Association and the National Cable and Telecommunications Association, and concluding that "the primary thrust of industry rhetoric ... valorizes unregulated competition and markets"). 
management of the Internet. ${ }^{137}$ They generally believe that Internet access is properly structured as a commodity service to be modeled on the electric grid:

The general purpose and neutral nature of the electric grid is one of the things that make it extremely useful. The electric grid does not care if you plug in a toaster, an iron, or a computer. Consequently it has survived and supported giant waves of innovation in the appliance market. ${ }^{138}$

For example, without a neutral electrical grid, an appliance manufacturer like Maytag could strike deals with utility companies, giving Maytag exclusive access to "high quality" current in exchange for some cut of Maytag's profits. ${ }^{139}$ A long history of public utility regulation has presumed the opposite-that "business affected with a public interest" should not be able to take advantage of its monopolistic or quasimonopolistic position to "pick winners" among the products and services dependent on the utility. ${ }^{140}$

By expanding the concept of a neutral electric grid to the digital age, Tim Wu has become one of the most prominent advocates for applying nondiscrimination principles to the Internet. He focuses on the "common carriage" requirements that telephone companies have had to respect since the Kingsbury Commitment of 1913, where AT\&T became a governmentsanctioned monopoly in exchange for divesting some of its current and future interests in other companies. ${ }^{141}$ Later, in the Hush-a-Phone and Carter-

137 See Jonathan L. Zittrain, The Generative Internet, 119 HARV. L. REV. 1974, 1978 (2006) (citing scholars who have argued for keeping the Internet "open").

${ }^{138}$ Tim Wu, Network Neutrality FAQ, http://timwu.org/network_neutrality.html (last visited Mar. 12, 2010).

139 See Herman, supra note 79, at 110 ("Just as the electrical grid gives innovators a stable, consistent system on which one can count in developing applications, a neutral broadband network permits innovators to plan based on stable expectations." (footnotes omitted)). Devices are increasingly capable of reporting user behavior back to product manufacturers. See, e.g., Randal C. Picker, Rewinding Sony: The Evolving Product, Phoning Home and the Duty of Ongoing Design, 55 CASE W. RES. L. REV. 749, 750-51 (2005) (suggesting a potential duty by manufacturers to report on copyright infringement, because "the feature set of the product is defined in many ways by [the software that it comes with]. ... [and] there are no natural boundaries to define the features of the product"). New advances in surveillance and reporting technology embedded in devices (such as RFID chips) encourage such business models. See Michael J. Madison, Law as Design: Objects, Concepts, and Digital Things, 56 CASE W. RES. L. REV. 381, 392-93 (2005) (describing the malleability of many devices and services on the Internet).

140 Charles M. HaAR \& Daniel WM. Fessler, The Wrong Side of the Tracks: A REVOLUTIONARY REDISCOVERY OF THE COMMON LAW TRADITION OF FAIRNESS IN THE STRUGGLE AGAINST INEQUALITY 133, 163-65 (1986); see also Jim Rossi, The Common Law "Duty to Serve" and Protection of Consumers in an Age of Competitive Retail Public Utility Restructuring, 51 VAND. L. REV. 1233,1239 (1998) ("[T] he public utility duty to serve . . . is comprised of distinct obligations to extend service, and to maintain certain quality standards once service commences.... [T] he obligations applicable to utilities are extraordinary, often requiring utilities to extend and provide service to customers where it is not always profitable to do so.").

$141 \mathrm{Wu}$, supra note 138 ("The concept of a 'common carrier,' dating from 16th century English common law, captures many similar concepts [as the term 'network neutrality']. A common carrier, in 
fone cases, ${ }^{142}$ antitrust enforcers successfully moved to prevent AT\&T from banning the attachment of objects to telephones that did not affect the quality of service generally. ${ }^{143}$ The FCC and the courts reasoned that the telephone company should not be permitted to control the development of all the devices that would eventually be capable of transmitting data over its lines. ${ }^{144}$

Advocates of nondiscrimination norms worry that the types of sharp practices that would make little sense in real space could easily be imposed in cyberspace. For example, it is hard to imagine why an airline would, say, refuse access to Marriott employees because it has a business relationship with Hyatt. ${ }^{145}$ Even if Hyatt leveraged such a deal, the uproar in the press would be enormous. However, when Comcast bid for control of Walt Disney in $2004,{ }^{146}$ it would have been easy for the company to engineer fast-track access to Disney content on its network had the takeover succeeded. Norms of fair play on the Internet are so fluid that the media would be unlikely to find this integration of content and conduit particularly remarkable. ${ }^{147}$

its original meaning, is a private entity that performs a public function ...."); AT\&T, Milestones in AT\&T History, http://www.att.com/history/milestones.html (last visited Mar. 12, 2010); see also Barbara A. Cherry, Maintaining Critical Rules to Enable Sustainable Communications Infrastructures, 24 GA. ST. U. L. REV. 947, 950 (2008) ("[A] historically accurate understanding of legal developments in the United States reveals the importance of common law principles of common carriage and public utility law-which include imposition of ex ante requirements on providers in the retail market-in generating the desired emergent properties of widely available, affordable and reliable transportation and telecommunications infrastructures.").

${ }^{142}$ Hush-A-Phone Corp. v. United States, 238 F.2d 266 (D.C. Cir. 1956); In re Use of the Carterfone Device in Message Toll Tel. Serv., 13 F.C.C.2d 420 (1968).

143 See Rob Frieden, Hold the Phone: Assessing the Rights of Wireless Handset Owners and Carriers 14-15 (Jan. 7, 2008) (unpublished manuscript, available at http://ssm.com/abstract=1081345). The Carterfone decision required the telephone companies to allow the attachment of modems and fax machines. Id. This decision was later reaffirmed by one of the most deregulatory FCC Chairmen in the agency's history, Michael Powell, in the "four freedoms" he aimed to guarantee to carriers' customers. Michael K. Powell, Chairman, FCC, Preserving Internet Freedom: Guiding Principles for the Industry, Remarks Delivered to the Silicon Flatirons Symposium on The Digital Broadband Migration: Toward a Regulatory Regime for the Internet Age 5 (Feb. 8, 2004), available at http://hraunfoss.fcc.gov/edocs public/attachmatch/DOC-243556A1.pdf ("[C]onsumers should be permitted to attach any devices they choose to the connection in their homes.").

144 See Hush-a-Phone, 238 F.2d at 269. The Hush-a-Phone was a rubber cup placed over a mouthpiece designed to enhance the privacy of phone conversations. Carriers claimed the right to prohibit such attachments, but were ultimately denied that prerogative by this decision. Id. at 267-69.

145 See Bill D. Herman, Opening Botllenecks: On Behalf of Mandated Network Neutrality, 59 FED. COMM. L.J. 103, 131-33 (2007) (arguing that even cable networks cannot be analogized to Intemet networks)

146 See Geraldine Fabrikant et al., Cable Giant Bids to Take Over Disney, N.Y. TIMES, Feb. 12, 2004, at A1.

${ }^{147}$ See, e.g., Guy Pessach, Copyright Law as Silencing Restriction on Noninfringing Materials: Unveiling the Scope of Copyright's Diversity Externalities, 76 S. CAL. L. REV. 1067, 1079 (2003) (discussing how "the pros and cons of copyright should be examined ... in terms of diversity" because copyright protection "influence[s] both democratic and individual meaning-making processes"); $c f$. 
Reacting against such quiescence, Frischmann and van Schewick urge a principle of network neutrality designed to "insulat[e] end users from market-driven restrictions on access and use." 48 They endorse fierce competition among application and content providers and believe that such competition will be possible only if broadband providers cannot "pick winners" by favoring certain competitors. ${ }^{149}$ They are skeptical of some programs that would allow network owners to "scan" packets of data to deterdetermine their nature and provenance. ${ }^{150}$ Instead, they propose a network that would not "distinguish between end uses, [would not] base access decisions or pricing on how those packets may be used," and would not "optimize the infrastructure for a particular class of end uses."151 Frischmann and van Schewick claim that nondiscrimination principles at an infrastructural layer are needed to ensure innovation in the content and application layers that run on top of it.

Frischmann and van Schewick acknowledge the current "pressure for property rights evolution so that network owners may more fully internalize externalities and appropriate the value of the Internet."152 However, they observe some clear divergences between maximizing the private gains of network owners and maximizing the overall social gains that unfettered Internet access can generate. Following Lawrence Lessig's ${ }^{153}$ and Yochai Benkler's ${ }^{154}$ principles, Frischmann and van Schewick argue that online innovation results from the Internet's open architecture, which allows anyone

Mark A. Lemley \& Lawrence Lessig, The End of End-to-End: Preserving the Architecture of the Internet in the Broadband Era, 48 UCLA L. REV. 925, 946 (2001) (contending that the cost of eliminating ISP competition in the cable market is borne by the market, not the consumer, as consumers do not feel any direct loss when new innovations are stifled).

148 Brett M. Frischmann \& Barbara van Schewick, Network Neutrality and the Economics of an Information Superhighway: A Reply to Professor Yoo, 47 JURIMETRICs J. 383, 386 (2007); see also Lemley \& Lessig, supra note 147, at 964 ("All we propose is that cable companies be permitted to charge consumers for access to their wires, but not be permitted to bundle ISP services together with wire access."); Tim Wu, Why Have a Telecommunications Law? Anti-Discrimination Norms in Communications, 5 J. ON TELECOMM. \& HIGH TECH L. 15, 17 (2006) ("The rule should be (1) a general norm that is technologically neutral, (2) in the form of an ex ante rule with ex post remedies, and (3) anchored on a model of consumers' rights.").

149 Frischmann \& van Schewick, supra note 148, at 420-23.

150 Id. at 387.

151 Id. at 386.

152 Id. at 387. Examples of this pressure are evident in MiCHAEL HELler, THE GRIdLOCK ECONOMY 80-84 (2008) (discussing network owners' desire to increase profits).

153 LAWRENCE LesSig, FreE CULTURE: How Big MEDia USES TEChNOLOGY AND THE LAW TO LOCK DOWN CULTURE AND CONTROL CREATIVITY 276-77, 282-306 (2004) ("What's needed is a way to say something in the middle-neither 'all rights reserved' nor 'no rights reserved' but 'some rights reserved'-and thus a way to respect copyrights but enable creators to free content as they see fit.").

154 YOCHAI BENKLER, THE WEALTH OF NETWORKS 470-73 (2006), available at http:/www.benkler.org ("To flourish, a networked information economy rich in social production practices requires a core common infrastructure, a set of resources necessary for information production and exchange that are open for all to use."). 
with a "better idea" to supplant dominant players (or at least to usurp some of their market share and attention). ${ }^{155}$ They acknowledge that the "end-toend principle acts as a limitation on the property rights of network owners," but insist that it is only a limitation to the extent that "fair use operates as a limitation on the rights of copyright owners." 156 The fair use analogy is felicitous; as Richard Posner has stated, an absolute bar on fair use could seriously undermine book sales by reducing the amount of uncensored information available about books. ${ }^{157}$ Though individual copyright holders may gain a great deal by, say, forbidding quotes from their books that may be treated negatively, the book industry in general would be negatively affected by the lack of quality information about its products.

During the Bush Administration, an impressive group of scholars and activists joined Frischmann and van Schewick in challenging the economic arguments against network neutrality. ${ }^{158}$ They are increasingly influential among communications policymakers in the Obama Administration. However, influential deregulationists continue to insist that the only proper role for government here is to remedy past discriminatory conduct (an antitrust model), rather than to legislate nondiscrimination or promulgate rules based on current statutes. ${ }^{159}$ The deregulationists have also argued that the FCC has not collected enough data to justify net neutrality regulations. ${ }^{160}$

Although former Senator Ted Stevens was roundly mocked for reminding network neutrality advocates that the Internet is "not a big truck,"161 it is

155 Frischmann \& van Schewick, supra note 148, at 387-89.

156 Id. at 386.

157 Ty, Inc. v. Publ'ns Int'l Ltd., 292 F.3d 512, 517 (7th Cir. 2002) (“[T]o deem such quotation an infringement would greatly reduce the credibility of book reviews, to the detriment of copyright owners as a group, though not to the owners of copyright on the worst books. Book reviews would no longer serve the reading public as a useful guide to which books to buy. Book reviews that quote from ('copy') the books being reviewed increase the demand for copyrighted works; to deem such copying infringement would therefore be perverse, and so the fair-use doctrine permits such copying."); see also Frank Pasquale, Copyright in an Era of Information Overload: Toward the Privileging of Categorizers, 60 VAND. L. REV. 135, 186-87 (2007) [hereinafter Pasquale, Categorizers] (discussing "captured categorizers").

158 See, e.g., Wu, supra note 102; Daniel J. Weitzner, The Neutral Internet: An Information Architecture for Open Societies (June 20, 2006) (unpublished manuscript, available at http://dig.csail.mit.edu/2006/06/neutralnet.pdf); Center for Democracy and Technology, Preserving the Essential Internet (June 2006) (unpublished manuscript, available at http://www.cdt.org/ speech/20060620neutrality.pdf).

159 See, e.g., Kahn, supra note 103, at 166.

${ }^{160}$ See Yoo, supra note 131, at 577; Opderbeck, supra note 136, at 217-18 (noting that the National Cable and Telecommunications Association has argued that " $[t]$ hose who call for regulation of the Internet in the name of 'network neutrality' are offering a solution in search of a problem since there is no evidence of a market failure justifying the imposition of common carrier-like regulation on broadband services").

161 Public Knowledge, Senator Stevens Speaks on Net Neutrality (June 28, 2006), http://www.publicknowledge.org/node/497; Communications Reform Bill: Full Committee Markup Be- 
difficult to invoke a metaphor that can capture the rapidly changing technologies deployed by carriers. Network neutrality advocates invoke railroads, electric grids, and highways to describe the Internet, and insist that economic theory valid in those realms can be applied to carriers. ${ }^{162}$ By contrast, opponents contend either that rival economic theories favor the deregulation or privatization of all of these transportation platforms, or that none of these platforms involve spam, viruses, "bandwidth hogs," or the type of contraband content now circulating on the web. ${ }^{163}$ Network neutrality opponents also argue that the cross-subsidization now practiced on airlines and some mail carriers should become part of network operators' business models. As Part III below demonstrates, transportation regulation may well constitute the wrong metaphor for modeling network management, if only because the cultural consequences of the latter are far more significant than those of the former. If content and application providers are willing to pay for priority access to consumers, should regulators deny them the opportunity to shift some of the burden of paying for broadband away from end users and toward those willing to pay to reach them?

Wholly economic methods of analysis cannot answer that question in a normatively satisfying manner. Economic analysis of the network neutrality question is essentially contested given the uncertain future development of technology in the field. ${ }^{164}$ The task now is to assure that corporate deployment of such technology responds to the cultural, political, and privacy interests of citizens, not just the demands of consumers.

\section{B. Search Policy as Competition Promotion}

Laissez-faire analysts argue that antitrust law provides ample remedies to penalize discrimination should it prove "anti-competitive." 165 They offer sponsored and independent research highlighting investment produced by deregulation and the resulting competition that would discipline discrimina-

fore the S. Comm. on Commerce, Science \& Transp., 109th Cong. (2006) (statement of Sen. Ted Stevens, Chairman, S. Comm. on Commerce, Science \& Transp.).

162 Lessig \& McChesney, supra note 112.

163 See, e.g., Scott Cleland, The Precursor Blog, Has Tim Wu Lost His Credibility? in His TunnelVision Piece: "Has AT\&T Lost Its Mind?", http://precursorblog.com/node/631 (Jan. 16, 2008, 17:55 EST) (arguing that net neutrality proposals will hamper carriers' ability to fight malware, spam, and bad actors). For a balanced overview of the communications law issues involved, see Rob Frieden, Internet Packet Sniffing and its Impact on the Network Neutrality Debate and the Balance of Power Between Intellectual Property Creators and Consumers, 18 FORDHAM INTELL. PROP. MEDIA \& ENT. L.J. 633 (2008).

164 See W.B. Gallie, Essentially Contested Concepts, 56 Proc. Aristotelian SOC'Y 167, 171-72 (1956) (describing the idea of the "essentially contested concept" as a term which cannot be defined neutrally, but instead is inevitably freighted with value judgments).

165 See Net Neutrality (Genny Pershing ed.), http://www.cybertelecom.org/ci/neutral.htm (last visited Mar. 12, 2010) ("Opponents [of net neutrality] argue that any harm caused by discriminatory behavior of networks can be adequately resolved by the ex post remedies of antitrust."). 
tory providers. ${ }^{166}$ In response, advocates of network neutrality have developed rival economic models demonstrating efficiency gains from enforceable prohibitions against discrimination. ${ }^{167}$ Even though these advocates welcome antitrust liability for anticompetitive deprioritization of carriers' rivals, they doubt antitrust actions would be initiated quickly enough to effectively deter discrimination. ${ }^{168}$ They seek forward-looking rules, not backward-looking antitrust litigation that would mire all concerned in years of discovery and second guessing by appellate courts increasingly skeptical of per se illegality. ${ }^{169}$

Although scholars rigorously defend network neutrality rules from a law and economics perspective, they risk falling into the same "antitrust trap" that they urge policymakers to avoid. Antitrust cases tend to consume a great deal of time, in part because economic conduct is subject to many different interpretations. ${ }^{170}$ One person's anticompetitive conduct is another's effective business strategy. The same unending (and indeterminate) arguments threaten to stall discourse on network neutrality and Internet governance generally. ${ }^{171}$ For example, the FTC's review of the Google-

166 See, e.g., Hance Haney, The AMERICAN CONSUMER INSTITUTE Center fOR Citizen RESEARCH, NETWORK NEUTRALITY REgulation WOULd IMPOSE CONSUMER WELFARE Losses, IN THE Consequences of Net Neutrality Regulations on Broadband INVESTMENT and CONSUMER WELFARE, A COLLECTION OF ESSAYS 50-51 (2009), available at http://www.theamericanconsumer.org/wp-content/uploads/2009/11/final-consequences-of-netneutrality.pdf.

${ }^{167}$ Trevor R. Roycroft, Economic Analysis and Network Neutrality: Separating Empirical Facts from Theoretical Fiction (June 2006) (unpublished issue brief, available at http://net.educause.edu/ir/library/pdf/EPO0652.pdf) (analyzing the effect of net neutrality from an economic perspective and concluding that network neutrality should not be abandoned).

168 Net Neutrality, supra note 165 ("Proponents [of net neutrality] argue that ... while anti trust [sic] serves to address the problem of excessive market power, it does so at a very slow pace and fails to adequately address consumer protection interests ....").

169 See, e.g., Leegin Creative Leather Prods., Inc. v. PSKS, Inc., 551 U.S. 877, 881 (2007) (overruling ninety-six year old doctrine of holding vertical price restraints per se illegal, holding instead that they "are to be judged by the rule of reason").

${ }^{170}$ See Jonathan Zittrain, The Un-Microsoft Un-Remedy: Law Can Prevent the Problem that It Can't Patch Later, 31 CONN. L. REV. 1361, 1361-62 (1999) ("The main concern in finding a remedy for ['bad monopolist behaviors'] may be time: The technology environment moves at a lightning pace, and by the time a federal case has been made out of a problem, the problem is proven, a remedy fashioned, and appeals exhausted, the damage may already be irreversible.").

171 See, e.g., Barbara A. Cherry, Misusing Network Neutrality to Eliminate Common Carriage Threatens Free Speech and the Postal System, 33 N. KY. L. REV. 483, 502 (2006) ("[T]o advocate primary reliance on antitrust principles ignores important historical facts. Common carriage regulation, both under the common law and statutorily, evolved prior to antitrust regulation. Thus, antitrust law subsequently evolved to augment-that is, to address issues and situations not already encompassed by - common carriage. ... Advocates of a regime based solely on antitrust fail to explain how the issues pertaining to the provider-to-customer relationship, that have been governed by the ex ante rules of industry-specific common carriage regulation, will be adequately addressed by antitrust ex post remedies." (footnotes omitted)). 
DoubleClick merger focused almost entirely on the economic effects of the proposed combination, rather than the threats to privacy it posed. ${ }^{172}$

Search engines are among the most innovative services in the global economy. They provide extraordinary efficiencies for advertisers and consumers by targeting messages to viewers who are most likely to want to receive them. In order to attract more users, search engines use revenues from advertising to organize and index a great deal of content on the Internet. ${ }^{173}$ Like the major broadcast networks search engines are now beginning to displace, they provide opportunities to view content (organic search results) in order to sell advertising (paid search results). ${ }^{174}$ Search engines have provoked antitrust scrutiny because proposed deals between major search engines (and between search engines and content providers) suggest undue coordination of competitors in an already concentrated industry. ${ }^{775}$

Those opposed to regulation often claim that antitrust law offers a more targeted and efficient response to abuses. As Justice Breyer explained in his classic work Regulation and Its Reform:

[T]he antitrust laws differ from classical regulation both in their aims and in their methods... [T] [Tey act negatively, through a few highly general provisions prohibiting certain forms of private conduct. They do not affirmatively order firms to behave in specified ways; for the most part, they tell private firms what not to do.... Only rarely do the antitrust enforcement agencies create the detailed web of affirmative legal obligations that characterizes classical regulation. ${ }^{176}$

172 News Release, FTC, Federal Trade Commission Closes Google/DoubleClick Investigation (Dec. 20, 2007), available at http:/www.ftc.gov/opa/2007/12/googledc.shtm ("The Commissioners . . wrote that 'as the sole purpose of federal antitrust review of mergers and acquisitions is to identify and remedy transactions that harm competition,' the FTC lacks the legal authority to block the transaction on grounds, or require conditions to this transaction, that do not relate to antitrust. Adding, however, that it takes consumer privacy issues very seriously, the Commission cross-referenced its release of a set of proposed behavioral marketing principles that were also announced today.").

${ }^{173}$ Pasquale, Categorizers, supra note 157, at 159-61 (describing the social function of many categorizers, including search engines).

174 According to the Google Home Page, "[W]e distinguish ads from search results or other content on a page by labeling them as 'sponsored links' or 'Ads by Google.' We don't sell ad placement in our search results, nor do we allow people to pay for a higher ranking there." Google, Inc., Corporate Information: Company Overview, http://www.google.com/corporate/ (last visited Mar. 12, 2010).

175 For example, the deal reached between Microsoft and Yahoo! that would have Microsoft's Bing search engine deliver results for searches on Yahoo! has provoked antitrust concerns both domestically and internationally. See Christopher S. Rugaber, Microsoft-Yahoo Deal to Face Tough Antitrust Probe, ABCNEws, July 29, 2009, http://abcnews.go.com/Technology/wireStory?id=8205494; see also Hearing, supra note 110, at 48 (statement of Frank Pasquale, Professor, Seton Hall University School of Law) ("Recent deals between major search engine providers have provoked scrutiny because they suggest undue coordination of competitors in an already concentrated industry.").

176 STEPHEN BREYER, REgUlation AND ITS REFORM 156-57 (1982). But see A. Douglas Melamed, Antitrust: The New Regulation, 10 ANTITRUST 13, 13 (1995) (describing "two paradigms," the law enforcement model and the regulatory model, and the shift of antitrust law from the former to the latter). 
Most scholars skeptical of network neutrality point to antitrust law as the proper limit on carriers' power. ${ }^{177}$ For some of them, the FCC is an anomaly, a vestigial regulator in thrall to an outdated style of commandand-control regulation. ${ }^{178}$ Many scholars reject governmental efforts to shape the development of Internet connectivity as industrial policy and believe that authorities should only be involved in order to remedy abuses, not to try to prevent them or to optimize communications generally.

In the case of search engines, that legal landscape currently exists. Actual and threatened antitrust investigations have shaped Google's business practices as its dominance in search grows. Many believe that the DOJ's suspicion of the company's proposed joint venture with Yahoo! in the search advertising field effectively scuttled the deal by late $2008 .{ }^{179}$ However, antitrust enforcement appears less promising in other situations involving intermediary technology. ${ }^{180}$ This section discusses the limits of antitrust in addressing the cultural and political dilemmas raised by Google's proposed Book Search deal with publishers, ${ }^{181}$ and its dominance of online advertising.

177 John Blevins, A Fragile Foundation-The Role of "Intermodal" and "Facilities-Based" Competition in Communications Policy, 60 ALA. L. REV. 241, 282 (2009) ("Antitrust remedies play an important role within deregulation debates because they provide a 'safety net' to address anticompetitive conduct in the absence of regulation.").

${ }^{178}$ See, e.g., Kahn, supra note 103, at 183 (asserting that the broadband market is not "suited for public utility-style regulation").

179 Nicholas Thompson \& Fred Vogelstein, The Plot to Kill Google, WIRED, Jan. 19, 2009, at 88, available at http://www.wired.com/techbiz/it/magazine/17-02/ff_killgoogle (noting that antitrust scrutiny culminated in a hearing in which the DOJ threatened to bring an antitrust case against Google and that one prominent DOJ attorney expressed the view that Google already is a monopoly). Of course, the antitrust laws do not flatly prohibit monopolies, only those attained via illicit means. See, e.g., Pac. Bell Tel. Co. v. Linkline Comm., Inc., 129 S. Ct. 1109, 1118 (2009) ("Simply possessing monopoly power and charging monopoly prices does not violate $\S 2$ [of the Sherman Act] ...."). For testimony, prepared but not delivered, that argued that some of Google's practices are suspect, see Testimony of Benjamin Edelman Scheduled Before the Task Force on Competition Policy \& Antitrust Laws of the H. Comm. on the Judiciary, June 27, 2008 (proposed testimony in front of hearing later cancelled, available at http://www.benedelman.org/publications/ppc-competition-071008.pdf ("Google sets reserve prices and other parameters that substantially determine prices.... Other Google practices, particularly Google's restrictions on export and copying of advertisers' campaigns, further hinder competition in Internet advertising-without any countervailing benefit whatever.").

180 Daniel Rubinfeld, Foundations of Antitrust Law and Economics, in HOW THE CHICAGO SCHOOL OVERSHOT THE MARK: THE EFFECT OF CONSERVATIVE ECONOMIC ANALYSIS ON U.S. ANTITRUST 51, 57 (Robert Pitofsky ed., 2008) (describing how "conservative economics has fostered a tendency to downplay enforcement in dynamic technological industries in which innovation issues play a significant role").

181 Despite the DOJ's intervention to affect the terms of the proposed settlement, many leading antitrust experts have argued that the settlement would not violate the antitrust laws. See, e.g., Einer Elhauge, Why the Google Books Settlement Is Pro-Competitive 58 (Harvard Law Sch., Law \& Econ. Discussion Paper No. 646, Harvard Law Sch., Pub. Law \& Theory Research Paper No. 09-4S, 2009), available at http://papers.ssm.com/sol3/papers.cfm?abstract_id=1459028 ("The settlement does not raise rival barriers to offering [many] books, but to the contrary lowers them. The output expansion is particularly dramatic for out-of-print books, for which there is currently no new output at all."); Amicus 
Privacy concerns are nearly impossible to address within the economic models of contemporary competition law. Antitrust scrutiny did little to address the privacy concerns raised when Google proposed to merge with the web advertising firm DoubleClick. ${ }^{182}$ The proposed deal provoked a complaint from the Electronic Privacy Information Center (EPIC) ${ }^{183}$ EPIC claimed that Google's modus operandi amounts to a "deceptive trade practice":

Upon arriving at the Google homepage, a Google user is not informed of Google's data collection practices until he or she clicks through four links. Most users will not reach this page... Google collects user search terms in connection with his or her IP address without adequate notice to the user. Therefore, Google's representations concerning its data retention practices were, and are, deceptive practices. ${ }^{184}$

One key question raised by the proposed merger was whether privacy and consumer protection concerns like these can be addressed by traditional antitrust analysis. ${ }^{185}$ Privacy law expert Peter Swire argued that they can, because "privacy harms reduce consumer welfare ... [and] lead to a reduction in the quality of a good or service."186 Swire believed that consumers would be worse off after the merger because of the unparalleled digital dossiers the combined entity could generate:

Google often has "deep" information about an individual's actions, such as detailed information about search terms. Currently, DoubleClick sets one or

Brief of Antitrust Law and Economics Professors as Amici Curiae in Support of the Settlement, Authors Guild v. Google, Inc., No. 05 CV 8136(DC) (S.D.N.Y. Sept. 8, 2009), 2009 WL 2980740, available at http://thepublicindex.org/docs/letters/antitrust_profs.pdf.

182 Dawn Kawamoto \& Anne Broache, FTC Allows Google-DoubleClick Merger to Proceed, CNET NEws, Dec. 20, 2007, http://news.cnet.com/FTC-allows-Google-DoubleClick-merger-to-proceed/21001024_3-6223631.html (describing U.S. authorities' blessing of the proposed deal). A similar dynamic obtained in Europe. See Press Release, Europa, Mergers: Commission Clears Proposed Acquisition of DoubleClick by Google (Mar. 11, 2008), available at http://europa.eu/rapid/pressReleasesAction .do?reference=IP/08/426\&format=HTML\&aged=0\&language $=E N \&$ guiLanguage $=$ en $\% 3$ Ehttp $/ /$ europa . eu/rapid/pressReleasesAction.do?reference $=I P / 08 / 426 \&$ format $=$ HTML\&aged $=0$ \&language=EN\&guiLa nguage =en ("The Commission's decision to clear the proposed merger is based exclusively on its appraisal under the EU Merger Regulation. It is without prejudice to the merged entity's obligations under EU legislation in relation to the protection of individuals and the protection of privacy with regard to the processing of personal data and the Member States' implementing legislation.").

183 EPIC, supra note 17.

184 See Complaint and Request for Injunction, Request for Investigation and for Other Relief, In re Google Inc. and DoubleClick, Inc., No. 071-0170 (FTC Apr. 20, 2007), available at http://epic.org/privacy/ftc/google/epic_complaint.pdf at 9 [hereinafter Google, Inc. and DoubleClick Complaint].

${ }^{185}$ See Siva Vaidhyanathan, The Googlization of Everything, Google and DoubleClick: A Bigger Antitrust Problem than I Had Imagined, http://www.googlizationofeverything.com/2007/ 10/google_and_doubleclick_a_bigge.php (Oct. 21, 2007, 16:05 EST).

186 Peter Swire, Protecting Consumers: Privacy Matters in Antitrust Analysis, CTR. FOR AM. PROGRESS, Oct. 19, 2007, http://www.americanprogress.org/issues/2007/10/privacy.html (italics omitted). 
more cookies on an individual's computers, and receives detailed information about which sites the person visits while surfing. DoubleClick has "broad" information about an individual's actions, with its leading ability to pinpoint where a person surfs. ${ }^{187}$

Initial points of contention include (a) the definition of the products at issue, and (b) how to weigh the costs and benefits of a merger. The combined company would have different segments of "customers" in a twosided market ${ }^{188}$ : (1) searchers trying to find sites, and (2) ad buyers trying to reach searchers. Swire contends that many people care about privacy, and "[i]t would be illogical to count the harms to consumers from higher prices while excluding the harms from privacy invasions-both sorts of harms reduce consumer surplus and consumer welfare in the relevant market."189

However, the web searcher category not only consists of consumers who care about privacy, but also includes many people who do not highly value it or who actively seek to expose their information in order to receive more targeted solicitations. According to Eric Goldman's work on personalized search, some may even consider the gathering of data about them to be a service. ${ }^{190}$ The more information is gathered about them, the better intermediaries are able to serve them relevant ads. Many economic models of web publication assume that users "pay" for content by viewing ads; ${ }^{191}$ they may effectively pay less if the advertisements they view bear some relation to things they want to buy. So while Swire models advertising and data collection as a cost to be endured, Google and DoubleClick argue that their

187 Swire, supra note 186. According to Swire, "[i]f the merger is approved, then individuals using the market leader in search may face a search product that has both 'deep' and 'broad' collection of information. For the many millions of individuals with high privacy preferences, this may be a significant reduction in the quality of the search product-search previously was conducted without the combined deep and broad tracking, and now the combination will exist." $I d$.

${ }^{188}$ For a definition of two-sided market, see Nicholas Economides \& Joacim Tåg, Net Neutrality on the Internet: A Two-Sided Market Analysis 1 (NET Inst., Working Paper No. 07-45, N.Y. Univ. Law and Econ., Research Paper No. 07-40, 2007), available at http://papers.ssm.com/sol3/papers.cfm?abstract_id $=1019121$ ("[P]latforms sell Internet access services to consumers and may set fees to content and applications providers 'on the other side' of the Internet."). In the search engine context, consumers "pay" by attending to ads, and ad-purchasers pay Google for the chance to get ad viewers' attention.

189 Swire, supra note 186.

190 Eric Goldman, A Coasean Analysis of Marketing, 2006 WIS. L. REV. 1151, 1162-64 ("Three components determine an individual consumer's utility from a marketing exposure: (1) the consumer's substantive interest in the marketing, (2) the consumer's nonsubstantive reactions to the marketing exposure, and (3) the attention consumed by evaluating and sorting the marketing.... [A] consumer may derive utility from the rote act of being contacted by marketers or exposed to the marketing, regardless of the marketing content.").

191 David S. Evans, The Economics of the Online Advertising Industry, 7 REV. NETWORK ECON. 359,359 (2008), available at http://www.bepress.com/rne/vol7/iss3/2 (describing how many of the top websites have adopted the "free-tv" model where the publisher generates traffic by not charging for readers but then sell that traffic to advertisers). 
tracking (and the ads that result from it) are a service to customers. ${ }^{192}$ Their arguments prevailed, and Google officially acquired DoubleClick in $2008 .{ }^{193}$

Antitrust law is ill prepared to handle a "market" where some percentage of consumers consider loss of privacy a gain and others consider it a loss. Economic reasoning in general falters in the face of externalities, ${ }^{194}$ but usually we can all agree that, say, pollution is a harm (or negative externality) and flowers are a boon (or positive externality). Privacy preferences are much more idiosyncratic.

Critics of the merger do have a response to this problem of diverse preferences-they can shift from characterizing lost privacy as a cost of web searching to describing it as a reduction in the quality of the services offered by the merging entities. ${ }^{195}$ Douglas Kysar's work on the productprocess distinction is encouraging here. Kysar has claimed that consumers should have a right to make choices of products based on how the products are made, not just how well they work. ${ }^{196}$ Kysar argues "in favor of acknowledging and accommodating [consumer] process preferences within

192 See Interview by Robert Siegel, NPR, with Eric Schmidt, CEO, Google, CEO: Google Knows $A$ Lot About You, Then Forgets (Oct. 2, 2009), available at http:/www.npr.org/templates/story/story.php? storyId=113450803 ("We work really, really hard to give you choices ... . [U]sers can entirely opt in or opt out or opt for something in between when it comes to Google saving their searches." (internal quotation marks omitted)). But Schmidt has also advised consumers that "[i]If you have something that you don't want anyone to know, maybe you shouldn't be doing it in the first place.... [T] search engines-including Google-do retain this information for some time and it's important, for example, that we are all subject in the United States to the Patriot Act and it is possible that all that information could be made available to the authorities." Bruce Schneier, My Reaction to Eric Schmidt, http://www.schneier.com/blog/archives/2009/12/my_reaction_to.html (Dec. 9, 2009, 12:22 EST) (quoting Eric Schmidt).

193 See Press Release, Google Inc., Google Closes Acquisition of DoubleClick (Mar. 11, 2008), available at http://www.google.com/intl/en/press/pressrel/20080311_doubleclick.html.

194 Compare Mark A. Lemley, Property, Intellectual Property, and Free Riding, 83 TEX. L. REV. 1031,1048 (2005) ("Tangible property law also implicitly rejects the idea that owners are entitled to capture all positive externalities. If I plant beautiful flowers in my front lawn, I don't capture the full benefit of those flowers-passers-by can enjoy them too. But property law doesn't give me a right to track them down and charge them for the privilege-though owners of property once tried unsuccessfully to obtain such a right." (footnotes omitted)), with HELLER, supra note 152, at 194 (discussing how business improvement districts force holdouts to help fund aesthetic improvements in their neighborhoods).

195 Swire, supra note 186. Both Supreme Court precedent and DOJ guidelines support this approach. See Nat'l Soc'y of Prof'l Eng'rs v. United States, 435 U.S. 679, 695 (1978) ("The assumption that competition is the best method of allocating resources in a free market recognizes that all elements of a bargain-quality, service, safety, and durability-and not just the immediate cost, are favorably affected by the free opportunity to select among alternative offers."); U.S. DEP'T OF JUSTICE, HORIZONTAL MERGER GUIDELINES § 4, at 30-32 (1997) (efficient market behavior is indicated by lower prices, new products, and "improved quality").

196 Douglas A. Kysar, Preferences for Processes: The Process/Product Distinction and the Regulation of Consumer Choice, 118 HARV. L. REV. 526, 529 (2004) ("[C]onsumer preferences may be heavily influenced by information regarding the manner in which goods are produced."). 
policy analysis, given the potential significance that such preferences may serve in the future as outlets for public-minded behavior." 197 Nevertheless, the valuation problems here are daunting. How are we to determine how much consumers are willing to pay to avoid privacy-eroding companies? ${ }^{198}$

Perhaps, as Lisa Heinzerling and Frank Ackerman suggest in their book Priceless, we should stop even trying to pretend that these decisions can be made on anything approaching a purely economic basis. ${ }^{199}$ Engaging in a cost-benefit analysis diminishes privacy's status as a right. Though many scholars have compellingly argued for broader foundations for competition law, the mainstream of contemporary antitrust policy in the United States cannot accommodate such concerns. ${ }^{200}$ Antitrust's summum bonum is the maximization of "consumer welfare," and this measure of efficiency is notoriously narrow. ${ }^{201}$ For example, the DOJ was hard pressed to adequately factor in a basic democratic commitment to diverse communicative channels during many media mergers. ${ }^{202}$

197 Id. at 534.

198 Christopher Yoo has demanded this kind of accounting in the context of net neutrality. See Yoo, Beyond Neutrality, supra note 106, at 54 ("There is nothing incoherent about imposing regulation to promote values other than economic welfare. ... [but] such a theory must provide a basis for quantifying the noneconomic benefits and for determining when those benefits justify the economic costs.").

199 FRANK ACKERMAN \& LISA HEINZERLING, PRICELESS: ON KNOWING THE PRICE OF EVERYTHING AND THE VALUE OF NOTHING 8-9 (1993) ("The basic problem with narrow economic analysis of health and environmental protection is that human life, health, and nature cannot be described meaningfully in monetary terms; they are priceless. When the question is whether to allow one person to hurt another, or to destroy a natural resource; when a life or a landscape cannot be replaced; when harms stretch out over decades or even generations; when outcomes are uncertain; when risks are shared or resources are used in common; when the people 'buying' harms have no relationship with the people actually harmedthen we are in the realm of the priceless, where market values tell us little about the social values at stake."). As Elizabeth Anderson has argued, "[t]o value or care about something in a particular way involves a complex of standards for perception, emotion, deliberation, desire, and conduct that express and thereby communicate one's regard for the object's importance." ELIZABETH ANDERSON, VALUE IN ETHICS AND ECONOMICS 11 (1993). It is often difficult or impossible to express such "perception, emotion, deliberation, desire, and conduct" in monetary terms. Id. at 11, 15-16.

200 See RICHARD POSNER, ANTITRUST LAW, at ix (2d ed. 2001) ("Almost everyone professionally involved in antitrust today--whether as litigator, prosecutor, judge, academic, or informed observernot only agrees that the only goal of the antitrust laws should be to promote economic welfare, but also agrees on the essential tenets of economic theory that should be used to determine the consistency of specific business practices with that goal.").

201 See Maurice E. Stucke, Better Competition Advocacy, 82 ST. JoHN's L. REV. 951, 1001 (2008) (observing the primacy of allocative efficiency in antitrust analysis). Stucke notes that "[b]ehind allocative efficiency's façade of positivism lie [many] moral questions...." Id. See also Julie E. Cohen, Network Stories, 70 LAW \& CONTEMP. PROBS. 91, 92 (2007) ("What makes the network good can only be defined by generating richly detailed ethnographies of the experiences the network enables and the activities it supports, and articulating a normative theory to explain what is good, and worth preserving, about those experiences and activities.").

202 See C. Edwin Baker, Media Concentration: Giving Up on Democracy, 54 FLA. L. REV. 839, 857 (2002) (" $[\mathrm{T}]$ he dominant antitrust focus on power over pricing can be distinguished from power over the content available for consumer choice. In the currently dominant paradigm, a merger that dramatically reduced the number of independent suppliers of a particular category of content-say, news or local 
Given antitrust doctrine's pronounced tendency to suppress or elide the cultural and political consequences of concentrated corporate power, the Bureau of Competition and the Bureau of Economics within the FTC are ill equipped to respond to the most compelling issues raised by search engines. ${ }^{203}$ The Google-Doubleclick merger proceedings ultimately ended with an overwhelming win for Google at the FTC. ${ }^{204}$ This outcome was all but inevitable given the foundations of contemporary antitrust doctrine, ${ }^{205}$ and is the logical outgrowth of overreliance on legal economic theory that uncritically privileges market outcomes. ${ }^{206}$ As long as contemporary doctrine holds that antitrust is singularly focused on the "consumer welfare" a proposed transaction will generate, ${ }^{207}$ antitrust policymakers will be unable to address the cultural and political consequences of consolidation in the search industry.

Antitrust challenges to the proposed settlement of a copyright lawsuit by authors and publishers against Google's Book Search program are likely to be similarly constrained. ${ }^{208}$ As in the Google-Doubleclick merger, the

news or Black activist news-creates no antitrust problem if, as likely, it does not lead to power to raise prices.").

203 See Statement of the Federal Trade Commission Concerning Google/DoubleClick, FTC File No. 071-0170 (FTC Dec. 20, 2007), available at http://ftc.gov/os/caselist/0710170/071220 statement.pdf [hereinafter STATEMENT OF FTC CONCERNING GOOGLE/DOUBLECLICK] ("Although [privacy concerns] may present important policy questions for the Nation, the sole purpose of federal antitrust review of mergers and acquisitions is to identify and remedy transactions that harm competition.").

204 Id.

205 Maurice Stucke describes and critiques this bias in some detail. See Stucke, supra note 201, at 1031 (describing a "mishmash of neoclassical economic theory, vignettes of zero-sum competition, and normative weighing of the anticompetitive ethereal-deadweight welfare loss-against the conjectures of procompetitive efficiencies" at the core of too much antitrust law and theory). Among his many important contributions to the literature, Stucke makes it clear that competition policy includes far more goals and tactics than antitrust enforcement alone. Id. at 987-1008.

${ }^{206}$ Reza Dibadj, Beyond Facile Assumptions and Radical Assertions: A Case for "Critical Legal Economics," 2003 UTAH L. REV. 1155, 1161 ("[T]hree of the most basic assumptions to the popular [law \& economics] enterprise-that people are rational, that ability to pay determines value, and that the common law is efficient--while couched in the metaphors of science, remain unsubstantiated."). But see JAMES R. HACKNEY, JR., UNDER COVER OF SCIENCE: AMERICAN LEGAL-ECONOMIC THEORY AND THE QUEST FOR OBJECTIVITY 164-66 (2007) (describing the "notable movement to broaden the scope of legal-economic theory under the rubric of socioeconomics").

207 See Leegin Creative Leather Prods., Inc. v. PSKS, Inc., 551 U.S. 877, 906 (2007) (acknowledging the economic foundations of U.S. antitrust law).

208 The Antitrust Division of the U.S. Department of Justice has weighed in to object to the settlement as it was presented to the court, and Judge Denny Chin ordered the parties to renegotiate its terms in October and early November 2009 in order to respond to these and other objections. Motoko Rich, Google and Authors Win Extension for Book Settlement, N.Y. TIMES, Nov. 9, 2009, at B3, available at http://www.nytimes.com/2009/11/10/technology/companies/10gbooks.html?_r=1; Brandon Butler, The Google Books Settlement: Who Is Filing and What Are They Saying 1-2, http://www.scribd.com/doc/20371700/The-Google-Books-Settlement-Who-Is-Filing-And-What-Are-

They-Saying (last visited Mar. 12, 2010) ("On September 18, 2009, the Department filed a Statement of Interest arguing that the terms of the Settlement do not ... adequately represent the members of the class ... [and] that the Settlement is in tension with the tenets of copyright law and that it creates serious 
privacy implications of Google's proposed deal with publishers are profound. $^{209}$ Anyone who cares about public input into the future of access to knowledge should approach the potential deal here warily, ${ }^{210}$ even if the prospect of constructing a digital library of Alexandria tempts scholars. ${ }^{211}$ As Harvard librarian Robert Darnton has argued, only a naive optimist could ignore the perils of having one profit-driven company effectively entrusted with a comprehensive collection of the world's books. ${ }^{212}$

When publishers challenged Google's book scanning in 2007, many hoped that public interest groups could leverage copyright challenges to Google's book search program to promote the public interest. Courts could condition a pro-Google fair use finding on universal access to the contents of the resulting database. Landmark cases like Sony v. Universal ${ }^{213}$ set a precedent for taking such broad public interests into account in the course of copyright litigation. ${ }^{214}$ Those who opt out of the settlement may be able to fight for such concessions, but for now the battle centers on challenges to the settlement itself.

Both James Grimmelmann ${ }^{215}$ and Pamela Samuelson have suggested several principles and recommendations to guide the court which must ap-

problems under antitrust law, as well."). The DOJ expressed dissatisfaction with the parties' most recent proposed settlement, as well. See Cecilia Kang, Judge Puts Off Ruling on Google's Proposed Digital Book Settlement, WASH. POST, Feb. 19, 2010, available at http://www.washingtonpost.com/wpdyn/content/article/2010/02/18/AR2010021800944.html?hpid=moreheadlines.

209 Electronic Frontier Foundation, Google Book Search Settlement and Reader Privacy, available at http://www.eff.org/issues/privacy/google-book-search-settlement (last visited July 11, 2010). As author Michael Chabon argues, "if there is no privacy of thought - which includes implicitly the right to read what one wants, without the approval, consent or knowledge of others - then there is no privacy, period." Id.

210 In response to the proposed Google Books Settlement, many substantive objections have been filed to be considered at the "fairness hearing" that is to precede final judicial approval of the settlement. Butler, supra note 208 ("The court . . has received a huge number of filings both from class-members and from other interested parties.").

211 See, e.g., Diane Leenheer Zimmerman, Can Our Culture Be Saved? The Future of Digital Archiving, 91 MINN. L. REV. 989, 990-91 (2007) (looking at the Google Book Search project as a means of saving culture and "explor[ing] whether saving culture and saving copyright can be made compatible goals").

${ }^{212}$ Robert Darnton, The Library in the New Age, 55 N.Y. REV. Books, June 12, 2008, at 39, available at http://www.nybooks.com/articles/21514.

213 Sony Corp. of Am. v. Universal City Studios, Inc., 464 U.S. 417, 442 (1984).

${ }^{214}$ Frank Pasquale, Breaking the Vicious Circularity: Sony's Contribution to the Fair Use Doctrine, 55 CASE W. RES. L. REV. 777, 790 (2005); see also Sony Corp. of Am., 464 U.S. at 454 ("[T]o the extent time-shifting expands public access to freely broadcast television programs, it yields societal benefits. ... [T] [ public interest in making television broadcasting more available. ... supports an interpretation of the concept of 'fair use' that requires the copyright holder to demonstrate some likelihood of harm before he may condemn a private act of time-shifting as a violation of federal law.").

215 James Grimmelmann is an Associate Professor at New York Law School and a member of its Institute for Information Law and Policy. He organized the foremost conference on the Google Book Search Settlement and maintains an online compendium of documents related to it, called The Public Index. See http://thepublicindex.org/ (last visited Mar. 12, 2010). 
prove the settlement. ${ }^{216}$ Grimmelmann's work has focused primarily on antitrust issues, ${ }^{217}$ while Samuelson has concentrated on the concerns of academic authors. ${ }^{218}$ Grimmelmann has succinctly summarized the settlesettlement's potential threats to innovation and competition in the market for book indices, and books themselves:

The antitrust danger here is that the settlement puts Google in a highly privileged position for book search and book sales.... The authors and publishers settled voluntarily with Google, but there's no guarantee they'll offer similar terms, or any terms at all, to anyone else.... [They] could unilaterally decide only to talk to Google. ${ }^{219}$

Grimmelmann proposes several methods of assuring that the publishers will deal with other book search services. ${ }^{220}$ Grimmelmann suggests an "[a]ntitrust consent decree" and "[n]ondiscrimination among copyright owners" as potential responses to the issues raised by the settlement. ${ }^{221}$ Most of his proposal reflects a policy consensus that presumes competition is the ideal solution to abuses of power online. ${ }^{222}$

Yet there are many reasons why competition is unlikely to arise in book search services, even if the settlement is altered in order to promote it. $^{223}$ Licensing costs are likely to be a substantial barrier to entry. A key to

${ }^{216}$ See Pamela Samuelson, Google Book Search and the Future of Books in Cyberspace, 94 MINN. L. REV. (forthcoming, 2010), available at http://digital-scholarship.org/digitalkoans/2010/01/13/googlebook-search-and-the-future-of-books-in-cyberspace/ (discussing the "six categories of serious reservations that have emerged about the settlement ... reflected in the hundreds of objections and numerous amicus curiae briefs filed with the court responsible for determining whether to approve the settlement"); Pamela Samuelson, Legally Speaking: The Dead Souls of the Google Booksearch Settlement, 52 COMMS. ACM, July 2009, at 28, available at http://papers.ssm.com/sol3/papers.cfm?abstract_id= 1387782 .

217 See generally James Grimmelmann, How to Fix the Google Book Search Settlement, 12 J. INTERNET L., Apr. 2009, at 1 (arguing that the Google Book Search antitrust case settlement should be approved with additional measures designed to promote competition and protect consumers).

218 Letter from Pamela Samuelson, Richard M. Sherman Distinguished Professor of Law, University of California, Berkeley School of Law, to Hon. Denny Chin, Judge, S.D.N.Y. (Sept. 3, 2009), available at http://www.scribd.com/doc/19409346/Academic-Author-Letter-090309 (urging the judge to condition "approval of the Settlement Agreement on modification of various terms identified herein so that the Agreement will be fairer and more adequate toward academic authors").

219 James Grimmelmann, In Google We Antitrust, TPMCAFÉ BoOK CluB, Jan. 15, 2009, http://tpmcafe.talkingpointsmemo.com/2009/01/15/in_google_we_antitrust.

220 Id.

221 Grimmelmann, supra note 217 , at 15 .

222 Grimmelmann does also propose some revised terms that would not be primarily designed to incentivize the development of new altematives to Google Book Search; for example, he proposes "[l]ibrary and reader representation at the [Book Rights R]egistry" that would administer many aspects of the settlement. $I d$.

${ }^{223}$ See Bracha \& Pasquale, supra note 65, at 1152 ("Though the market choices of users and technological developments constrain search engine abuse to some extent, they are unlikely to vindicate [certain social] values...."); Frank Pasquale, Seven Reasons to Doubt Competition in the General 
competition in the search market is having a comprehensive database of searchable materials; the more these materials need to be licensed, the less likely it is that a second comer can set up its own book archive. As scholars have demonstrated, deals like Google's proposed settlement help entrench copyright holders' claims for licensing revenue. ${ }^{224}$ Moreover, innovation in search is heavily dependent on having an installed base of users that effectively "train" the search engine to be responsive. ${ }^{225}$ The more search queries an engine gets, the better able it is to sharpen and perfect its algorithm..$^{26}$ Each additional user tends to decrease the cost of a better quality service for all subsequent users by contributing activity that helps the search engine differentiate between high and low quality organizational strategies. ${ }^{227}$ Thus, incumbents with large numbers of users enjoy substantial advantages over smaller entrants. Restrictive terms of service also deter competitors who aspire to reverse engineer and develop better versions of such services. ${ }^{228}$ In general purpose search, users cannot reproduce, copy, or resell any Google service for any reason, even if the behavior is manual and nondisruptive. ${ }^{229}$ Another section proscribes "creat[ing] a derivative work of...the Software."230 Advertisers face other restrictions, as

Search Engine Market, MADISONIAN, Mar. 18, 2009, http://madisonian.net/2009/03/18/seven-reasonsto-doubt-competition-in-the-general-search-engine-market.

${ }^{224}$ See James Gibson, Risk Aversion and Rights Accretion in Intellectual Property Law, 116 YALE L.J. 882, 884 (2007) (describing how the decision as to whether to fight for fair use or license a copyrighted work can be difficult "because the penalties for infringement typically include supracompensatory damages and injunctive relief"). The existence of a licensing market often leads courts to conclude that uses should be licensed: "[c]ombine these doctrinal gray areas and severe consequences with the risk aversion that pervades key copyright industries, and the result is a practice of securing copyright licenses even when none is needed." Id. Now that Google has agreed to license the books that will be indexed in its book search, it is likelier that potential new entrants will need to license these books as well. Given the law's dependence on industry practices as a benchmark for fair use determinations, their legal case for free use of the relevant works has weakened.

225 James Pitkow et al., Personalized Search, 45 COMMS. ACM, Sept. 2002, at 50 (discussing methods of personalizing search systems); Elinor Mills, Google Automates Personalized Search, CNET NEws, June 28, 2005, http://www.news.com/Google-automates-personalized-search/2100-1032_35766899.html (reporting that Google launched a new version of its personalized search that monitors previous searches to refine future results).

226 For example, if 100 people search for "alternatives to Microsoft Word software" on a search engine on a given day and all pick the third-ranked result, the search algorithm may adjust itself and put the third-ranked result as the first result the next day. The most-used search engine will have more data to tweak its algorithms than its less-used rivals.

${ }^{227}$ For a fuller explanation of one facet of this process, see the discussion supra note 50 (describing fine-tuning of results via personalized search).

228 Though the precise terms of service of Google Book Search have not been finalized, Google's more general terms of service are not promising. Google's terms of service prohibit any action that "interferes with or disrupts" Google's services, networks, or computers. Google Inc., Terms of Service $\S 5.4$ (Apr. 16, 2007), http://www.google.com/accounts/TOS. Repeated queries to the service necessary to gather data on its operations may well violate these terms.

229 Id. $\S 5.5$.

${ }^{230}$ Id. $\S 10.2$. Together, these sections of the TOS explicitly forbid much of the data harvesting that might be necessary for rival firms to incrementally innovate beyond the current capacities of Google's 
Google's AdWords API Terms \& Conditions "impede advertisers' efforts to efficiently copy their ad campaigns to other providers."231 All of these factors militate against robust competition in the comprehensive book search field.

Quantum leaps in technology capable of overcoming these brute disadvantages are unlikely, particularly because search is as much about personalized service as it is about technical principles of information organization and retrieval. ${ }^{232}$ Current advantage in search is likely to be self-reinforcing, especially given that so many more people are using the services now than when Google overtook other search engines in the early 2000 s. $^{233}$

What does an online world featuring an entrenched Google Book Search as gatekeeper look like? Initially, it will prove a vast improvement on the status quo of bulky, hard-to-acquire, physical copies of books. But when we consider the ways in which knowledge can be rationed for profit some worries arise. Google plans to monetize the book search corpus, and one predictable way of increasing its value is to make parts of it unavailable to those unwilling to pay high licensing fees. If the settlement were allowed to charge such fees in an unconstrained manner, unmoored from the underlying costs of operating the project, Google would essentially be exploiting a public easement (to copy books) for unlimited private gain. The Open Content Alliance ${ }^{234}$ has questioned the restrictive terms of the contracts that Google strikes when it agrees to scan and create a digital database of a library's books. ${ }^{235}$ Those restrictive terms foreshadow potential future restrictions on book search services. The proposed deal raises fun-

services. Commercial scraping of data, such as the use of software to automatically gather data from the Google service by a competitor to establish a rival search engine, is prohibited by multiple sections. Section 5.3 would proscribe both the automatic data collection and the use of a nonapproved "interface" for accessing Google's database, regardless of the exact means. Id. $\S 5.3$.

231 Edelman, supra note 179 (arguing that "Google's restrictions on export and copying of advertisers' campaigns ... hinder competition in Internet advertising"). Though the hearing at which Professor Edelman was to testify was cancelled, he has documented these problems in some detail at his website, http://www.benedelman.org.

232 BATTELLE, supra note 35, at 8 (describing how personalized search enhances the value of search engines to both users and advertisers). Due to trade secrecy, it is impossible for policymakers to discover how much of the intermediary's success is due to its employees' inventive genius, and how much is due to the collective contributions of millions of users to the training of the intermediary's computers.

${ }^{233}$ See RANDALl STROSS, PLANET GoOGLE 98 (2008) (describing success of YouTube, a subsidiary of Google).

234 Open Content Alliance Home Page, http://www.opencontentalliance.org (last visited Mar. 12, 2010).

${ }^{235}$ See Open Content Alliance, Let's Not Settle for This Settlement, http://www.opencontentalliance.org/2008/1 1/05/lets-not-settle-for-this-settlement (last visited Mar. 12, 2010) ("At its heart, the settlement agreement grants Google an effective monopoly on an entirely new commercial model for accessing books. It re-conceives reading as a billable event. This reading event is therefore controllable and trackable. It also forces libraries into financing a vending service that requires they perpetually buy back what they have already paid for over many years of careful collection."). 
damental questions about the proper scope of private initiative in organizing and rationing access to knowledge.

Well-funded libraries may pay a premium to gain access to all sources; lesser institutions may be granted inferior access. If permitted to become prevalent, such tiered access to information could rigidify and reinforce existing inequalities in access to knowledge. ${ }^{236}$ Information tiering inequitably disadvantages many groups, promoting the leveraging of wealth into status, educational, or other occupational advantage. Information is not only intrinsically valuable, but also can be a positional good, useful for scoring advantages over others. ${ }^{237}$

Admittedly, Google Book Search has already proven a great resource for scholars. It has made "book learning accessible on a new, worldwide scale, despite the great digital divide that separates the poor from the computerized." 238 Current access to knowledge is stratified in many troubling ways; the works of John Willinsky ${ }^{239}$ and Peter Suber ${ }^{240}$ identify many troubling current forms of tiering that pale before the present impact of Google Book Search. ${ }^{241}$ Given the aggressive pricing strategies of many publishers and content owners, Google Book Search is a vital alternative for scholars.

${ }^{236}$ Frank Pasquale, Technology, Competition, and Values, 8 MINN. J. L. SCI. \& TECH. 607, 608 (2007) (explaining how "much technology is used not just simply to improve its user's life, but also to help its user gain advantage over others"). For example, "[t]est-preparation technologies ... creat[e] inequalities; students able to afford test-preparation courses, such as those offered by Kaplan, have a definite advantage over those who do not have access to such courses." Id. at 615 (internal citation omitted).

237 Harry Brighouse \& Adam Swift, Equality, Priority, and Positional Goods, 116 ETHICs 471, 472 (2006) ("'Positional goods] are goods with the property that one's relative place in the distribution of the good affects one's absolute position with respect to its value. The very fact that one is worse off than others with respect to a positional good means that one is worse off, in some respect, than one would be if that good were distributed equally. So while it might indeed be perverse to advocate leveling down all things considered, leveling down with respect to positional goods benefits absolutely, in some respect, those who would otherwise have less than others."); Nestor Davidson, Property and Relative Status, 107 MICH. L. REV. 757, 757 (2009) ("[P]erhaps the most ubiquitous and important messages that property communicates have to do with relative status, with the material world defining and reinforcing a variety of economic, social, and cultural hierarchies."); Robert H. Frank, Are Concerns About Relative Income Relevant for Public Policy?: Positional Externalities Cause Large and Preventable Welfare Losses, 95 AM. ECON. REV. 137, 137 (2005) ("[E]conomic models in which individual utility depends not only on absolute consumption, but also on relative consumption . . . identify a fundamental conflict between individual and social welfare.").

238 Damton, supra note 212 , at 76.

239 JOHN WILLINSKY, THE ACCESS PRINCIPLE 5 (2005) (describing extreme "digital divide" between those most connected to information resources and those cut off from them).

${ }^{240}$ See generally Peter Suber, Open Access News, http://www.earlham.edu/ peters/fos/fosblog html. Suber is a leader of the open access movement, which aims to "[p]ut[] peer-reviewed scientific and scholarly literature on the internet[,] [m]ak[e] it available free of charge and free of most copyright and licensing restrictions[,] [and] remov[e] the barriers to serious research." Id.

241 See id. (chronicling on a daily basis news and controversies related to open access to scholarly materials on the Internet). 
Nevertheless, there is no guarantee in the current version of the settlement that Google Book Search will preserve its public-regarding features. ${ }^{242}$ It may well end up like the powerful "group purchasing organizations" in the American health care system that started promisingly, but have evolved to exploit their intermediary role in troubling ways. ${ }^{243}$ Google is more than just one among many online service providers jostling for a competitive edge on the web. It is likely to be the key private entity capable of competing or cooperating with academic publishers and other content providers. Dedicated monitoring and regulation of the settlement terms now could help ensure that book digitization protects privacy, diverse stakeholder interests, and fair pricing of access to knowledge. Alliances between Google Book Search and publishers deserve public scrutiny because they permit private parties to take on what have often been public functions of determining access to and pricing of information. Where "regulatory copyright" ${ }^{244}$ has answered such questions with compulsory licenses, ${ }^{245}$ the new alliances aspire to put into place a regime of cross-subsidization resistant to public scrutiny or input. ${ }^{246}$ Given the vital public interests at stake in the

\footnotetext{
${ }^{242}$ Siva Vaidhyanathan, The Googlization of Everything, Global Google, http://www.googlizationofeverything.com/2009/01/baiducom_accused_of_rigging_se.php (Feb. 19, $2009,14: 20$ EST) ("Public failure' [is a] phenomenon in which a private firm steps into a vacuum created by incompetent or gutted public institutions. A firm does this not for immediate rent seeking or even revenue generation. It does so to enhance presence, reputation, or to build a platform on which to generate revenue later or elsewhere. It's the opposite of 'market failure.' And it explains a lot of what Google does.").

243 For background on group purchasing organizations, see S. PRAKASH SETHI, GROUP PURCHASING ORganizations: AN UNDiSClOSED SCANDAL IN THE U.S. HEALTH CARE INDUSTRY 122 (Palgrave/MacMillan 2009) ("The benefits of combined purchases would be greatly reduced in conditions where the middlemen . . . control the entire process through restrictive arrangements with suppliers and customers.").

${ }^{244}$ See Joseph P. Liu, Regulatory Copyright, 83 N.C. L. REV. 87, 91 (2004) (describing the growth and scope of compulsory licensing statutes that provide for compensation for copyright holders while denying them the right to veto particular uses of their work).

${ }^{245}$ Marybeth Peters, the U.S. Register of Copyrights, has objected to the proposed Google Books Settlement on the grounds that it would violate traditional norms of separation of powers in copyright policy. See Hearing on Competition and Commerce in Digital Books: The Proposed Google Book Settlement Before the H. Comm. On the Judiciary, 111 th Cong. (2009) (statement of Marybeth Peters, Register of Copyrights), available at http://judiciary.house gov/hearings/pdf/Peters090910.pdf, at 2 ("In the view of the Copyright Office, the settlement proposed by the parties would encroach on responsibility for copyright policy that traditionally has been the domain of Congress. . . We are greatly concerned by the parties' end run around legislative process and prerogatives, and we submit that this Committee should be equally concerned.").

${ }^{246}$ Google considers its pricing and ranking decisions a closely held trade secret-an assertion that would seem very strange if it came from a public library. See Pamela Samuelson, Google Books Is Not a Library, HUFFINGTON POST, Oct. 13, 2009, http://www.huffingtonpost.com/pamelasamuelson/google-books-is-not-a-lib_b_317518.html ("Libraries everywhere are terrified that Google will engage in price-gouging when setting prices for institutional subscriptions to [Google Book Search] contents.").
} 
development of this information infrastructure, monitoring is vital. ${ }^{247}$ Extant law provides little assurance that it will actually occur.

\section{WHAT COMPETITION AND INNOVATION MISS}

The last section has described shortcomings of mainstream debates over net neutrality and Google's growing power. These debates are partial in two senses. They are incomplete because they are primarily focused on the current and potential travails of online businesses (rather than those of individual Internet users). They are also partial in the sense of being biased, because they assume a methodological individualism that obscures the social values at stake in the development of communications infrastructure. This Part responds to both biases by exploring the limits of individualism in responding to problems of privacy and consumer protection. There are important structural similarities between ISPs and search engines. In each realm, dominant intermediaries tend to gain more information about their users, while shrouding their own business practices in secrecy. Internet policy needs to address the resulting asymmetry of power.

\section{A. Privacy: An Irreducibly Social Practice}

Leading scholars have modeled privacy as a purchasable commodity: as with other products, individuals have varying preferences and abilities to pay for more or less privacy. ${ }^{248}$ On this economistic view, firms will emerge to compete to offer more or less privacy or will provide customers with various "privacy settings" to permit them to tailor their online services. Unfortunately, each of these assumptions is problematic, especially when we reflect on the zero-sum nature of reputational capital in many settings.

Competition is often elevated as a solution to the privacy problem, but few Internet intermediaries do (or even can) compete to grant users more privacy. While net neutrality's opponents have been promoting competition as a cure-all for years, ninety-four percent of broadband users have, as Professor Tim Wu notes, a choice of "zero, one, or two" carriers. ${ }^{249}$ Even in the more competitive mobile market, it is virtually unheard of for consum-

${ }^{247}$ In other work, I have proposed the creation of a "public option" in book search, which might reduce the need for monitoring of private entities. See Frank Pasquale, The Troubling Consequences of Trade Secret Protection for Search Engine Rankings, in THE LAW AND THEORY OF TRADE SECRECY: A HANDBOOK OF CONTEMPORARY RESEARCH (Rochelle C. Dreyfuss \& Katherine J. Strandburg eds., Edward Elgar Publishing, forthcoming 2010) ("Like private health insurers, Google is a middleman, standing between consumers and producers of knowledge.... If search engines consistently block or frustrate measures to increase their accountability, governments should seriously consider funding public alternatives."). This Article assumes that such a "public option" is unlikely to materialize in the near future.

248 See, e.g., Richard Posner, Blackmail, Privacy, and Freedom of Contract, 141 U. PA. L. REV. 1817,1822 (1993) (discussing blackmail as a payment for secrecy).

249 See Wu Statement, supra note 72 , at 45. 
ers to bargain for more or less privacy, or for carriers to compete on those terms.

Instead, carriers are beginning to compete in ways that are corrosive to privacy. As Paul Ohm has documented, "[b]roadband ISPs have ... search[ed] for new sources of revenue... [by] 'trading user secrets for cash,' which Google has proved can be a very lucrative market."250 While user protests have deterred the most abusive practices, Ohm predicts that "ISPs, faced with changes in technology, extraordinary pressures to increase revenues, and murky ethical rules, will continue aggressively to expand network monitoring."251 Antitrust law has been slow to recognize privacy as a dimension of product quality, and the competition that it promotes can do as much to trample privacy as to protect it.

Intermediary competition is supposed to provide users with more companies offering more options. However, competition is based primarily on immediately experienced aspects of the service, such as price and speed. The prospect of altering the terms of service for an intermediary like Facebook or Google is beyond the ambition of almost all users. ${ }^{252}$

Even intermediaries with intimate knowledge of users' communications with family and friends have tended to assert almost unlimited powers over user-generated content. ${ }^{253}$ The social networking site Facebook attempted to legitimate this power by creating a system that allowed its users to "vote" for changes to the terms of service before they are implemented. ${ }^{254}$

${ }^{250} \mathrm{Ohm}$, supra note 36 , at 17 (describing the many commercial pressures leading carriers to "monetize[] behavioral data at the expense of user privacy").

${ }^{251}$ Id. at 24; see also Jon D. Michaels, All the President's Spies: Private-Public Intelligence Partnerships in the War on Terror, 96 CAL. L. REV. 901,913 (2008) ("Indeed, Qwest's former CEO now explicitly alleges that the NSA retaliated against his uncooperative firm by canceling contracts worth hundreds of millions of dollars."); Leslie Cauley, NSA Has Massive Database of Americans' Phone Calls, USA TODAY, May 11, 2006, at A1. The National Security Agency "suggested that Qwest's [refusal to engage in certain forms of surveillance] might affect its ability to get future classified work with the government. Like other big telecommunications companies, Qwest already had classified contracts and hoped to get more." Id.

252 Mark A. Lemley, Terms of Use, 91 MINN. L. REV. 459, 469 (2006) ("[N]o one reads [many of these] forms of contract anyway ...."); Yannis Bakos, Florencia Marotta-Wurgler \& David R. Trossen, Testing a Law and Economics Approach to Standard Form Contracts 1 (N.Y.U. Law and Econ. Working Papers, Paper No. 195, 2009), available at http://lsr.nellco.org/cgi/viewcontent.cgi?article=1199\& context=nyu_lewp ("We track the Internet browsing behavior of 45,091 households with respect to 66 online software companies to study the extent to which potential buyers access the associated important standard form contract, the end user license agreement. We find that only one or two out of every thousand retail software shoppers chooses to access the license agreement, and those few that do spend too little time, on average, to have read more than a small portion of the license text.").

${ }^{253}$ Chris Walters, Facebook's New Terms of Service: "We Can Do Anything We Want with Your Content. Forever.", CONSUMERIST, Feb. 15, 2009, http://consumerist.com/5150175/facebooks-newterms-of-service-we-can-do-anything-we-want-with-your-content-forever.

254 Posting of Mark Zuckerberg to the Facebook Blog, Governing the Facebook Service in an Open and Transparent Way, http://blog.facebook.com/blog.php?post=56566967130 (Feb. 26, 2009, 11:20 EST). 
However, University of Cambridge researchers have released a detailed report which concludes that Facebook's system is merely "democracy theatre" with little practical effect on the company's operations. ${ }^{255}$

These examples exemplify a common theme: as the use and reuse of personal information becomes more deeply rooted in intermediary business practices, the tension between competition and privacy becomes more pronounced. For example, if a user of one social network wants to join another, she will often be reluctant to do so because of "switching costs"; she has already invested some time and effort in creating her existing profile. The chief way of reducing those costs is to require data portability, which would allow users to take their list of contacts, applications, pictures, and other items with them when they want to leave. However, such a rule (or protocol for data storage) can render the rest of the user's social graph vulnerable to unwanted exposure on the network the user migrates to. ${ }^{256}$ Randal Picker has described the deep tension between competition and privacy that results, arguing that this tension creates an incentive for greater consolidation of user information. ${ }^{257}$ Given these patterns of industry practice and consumer behavior, privacy regulators' monitoring of oligopolistic online entities will be more effective than waiting for the elusive concept of "privacy competition."

The classic laissez-faire approach here is to assume that the market will address any lingering privacy concerns. Firms will meet a market demand for privacy as individuals exit services that become too invasive of their privacy. However, established social dynamics render that faith in uncoordinated action suspect. Given the steady decline in individuals' expectations of privacy, both privacy and the reputations built on personal information might better be considered irreducibly social goods than some

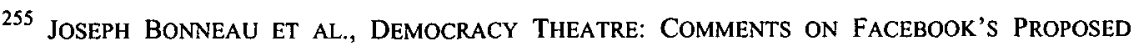
GOVERNANCE SCHEME (Mar. 29, 2009), http://www.cl.cam.ac.uk/ jcb82/2009-03-29-facebookcomments.pdf. Bonneau's report has been endorsed by the Open Rights Group. Posting of Jim Killock to Open Rights Group Blog, Facebook's Theatrical Rights and Wrongs, http://www.openrightsgroup.org /blog/2009/facebooks-theatrical-rights-and-wrongs (Apr. 1, 2009).

256 James Grimmelmann, Saving Facebook, 94 IOWA L. REv. 1137, 1194 (2009) (arguing against broad regulation requiring data portability on social networks because "it creates horizontal privacy trouble"). Grimmelmann notes that "[e]veryone who has access to 'portable' information on social network site $A$ is now empowered to move that information to social network site $B$. In the process, they can strip the information of whatever legal, technical, or social constraints applied to it in social network site $A . .$. [M] andatory data-portability rules create a privacy race to the bottom for any information subject to them." Id.

257 Randal C. Picker, Competition and Privacy in Web 2.0 and the Cloud, 103 NW. U. L. REV. COLLOQUY 1, 11-12 (2008) ("An uneven playing field that allows one firm to use the information that it sees while blocking others from doing the same thing creates market power through limiting competition. We rarely want to do that. And privacy rules that limit how information can be used and shared across firms will artificially push towards greater consolidation, something that usually works against maintaining robust competition."). 
quanta of enjoyments individuals trade off for money. ${ }^{258}$ Once commodified, privacy and reputational integrity are inevitably parceled out to rich and poor on differential terms. Moreover, given the frequently abstract "benefits" that privacy and reputational integrity afford, they are often traded away for competitive economic advantage. ${ }^{259}$ This process further erodes the societal expectations of privacy that underwrite respect for reputational integrity. ${ }^{260}$

A collective commitment to privacy is far more valuable than a private, transactional approach that all but guarantees a race to the bottom. ${ }^{261}$ Network neutrality regulations can include rules that will protect the privacy that market competition, left on its own, will inevitably erode. One expert even predicts that privacy concerns will "reinvigorate [the] stagnant debate [over network neutrality] by introducing privacy and personal autonomy into a discussion that has only ever been about economics and innovation."262 Reputational concerns should also be a larger part of public policy for search engine intermediaries, as discussed in Part IV below.

\section{B. Search and Carriage as Credence Goods}

One major impediment to users' monitoring of intermediary performance is a systematic information gap. If an individual uses an intermediary to find or contact a known entity and no relevant result appears, she is likely to switch to a competitor; so too will a carrier's reported blocking of certain sites or applications raise their devotees' ire. But it is difficult or impossible for consumers to detect less drastic manipulations of results. Both search for and carriage of information tend to be "credence goods,"

${ }^{258}$ Charles Taylor, Irreducibly Social Goods, in PHILOSOPHICAL ARgUMENTS 127, 139 (1995) (critiquing both subjectivism and methodological individualism and insisting that irreducibly social goods "exist[] not just for me and for you, but for us, acknowledged as such").

${ }^{259}$ Cass Sunstein and Robert H. Frank suggested in their work on cost-benefit analysis and relative position that those who trade off safety or other intangibles will have additional resources to outcompete peers who refuse to do so. See Robert H. Frank \& Cass R. Sunstein, Cost-Benefit Analysis and Relative Position, 68 U. CHI. L. REV. 323, 327 (2001) (discussing "the central importance of relative economic position to people's perceptions of their own well-being").

$260 I d$. at 323 . The theory of safety in Sunstein and Frank's work applies just as well to privacy. Id. at 326 ("[W] $[$ hen a regulation requires all [individuals to purchase] additional safety, each ... gives up the same amount of other goods, so no [one] experiences a decline in relative living standards. [The upshot is that] an individual will value an across-the-board increase in safety more highly than an increase in safety that he alone purchases.").

261 Siva Vaidhyanathan, Naked in the Nonopticon, CHRON. HIGHER EDUC., Feb. 15, 2008, at B7 ("When we complain about infringements of privacy, what we really demand is some measure of control over our reputation in the world. Who should have the power to collect, cross-reference, publicize, or share information about us, regardless of what that information might be? ... 'Self help' [in this context] merely ratchets up the arms race of surveillance.").

${ }^{262} \mathrm{Ohm}$, supra note 36, at 1; see also id. ("[T]his Article injects privacy into the network neutrality debate-a debate about who gets to control innovation on the Internet. Despite the thousands of pages that have already been written about the topic, nobody has recognized that we already enjoy mandatory network neutrality in the form of expansive wiretapping laws."). 
whose value a consumer will have difficulty evaluating even after consuming it. ${ }^{263}$ Often the user will have no idea that results are being manipulated in a particular way.

This is one reason why the Federal Trade Commission has issued a guidance to search engines regarding separation of paid and editorial content. In 2000 , the FTC stated that "[t]he same consumer protection laws that apply to commercial activities in other media apply online. The FTC Act's prohibition on 'unfair or deceptive acts or practices' encompasses Internet advertising, marketing and sales." ${ }^{264}$ Though that report did not explicitly address paid ads on search engines, its general argument appears to apply to that mode of advertising. For example, the report says that "the key is the overall net impression of the ad-that is, whether the claims consumers take from the ad are truthful and substantiated." ${ }^{265}$ Recent guidances for bloggers leave little doubt that the agency (at least under current leadership) is committed to requiring disclosure of commercial influence on online content. ${ }^{266}$

Even if we assume that search engines abide by the FTC's specific guidance letter issued in response to complaints about their practices ${ }^{267}$ and

263 See George A. Akerlof, The Market for "Lemons": Quality Uncertainty and the Market Mechanism, 84 Q. J. ECON. 488 (1970) (discussing economic models involving "trust" and uncertain quality); Kenneth J. Arrow, Uncertainty and the Welfare Economics of Medical Care, 53 AM. ECON. REV. 941, 947, 965-66 (1963) (discussing behaviors influenced by information inequality in a medical context); Michael R. Darby \& Edi Karni, Free Competition and the Optimal Amount of Fraud, 16 J.L. \& ECON. 67, 68-72 (1973) (exploring credence goods where quality cannot be evaluated through normal use but only at additional cost).

264 FTC, DOT COM DISCLOSURES, supra note 16, ๆ 1 , at 1.

265 ld. at 5 (footnote omitted).

${ }^{266}$ See FTC Guides Concerning the Use of Endorsements and Testimonials in Advertising, 16 C.F.R. $\$ 255$ (2009), available at http://www.ftc.gov/os/2009/10/091005endorsementguidesfnnotice .pdf (requiring disclosure of sponsorship or consideration offered in exchange for "any advertising message (including verbal statements, demonstrations, or depictions of the name, signature, likeness or other identifying personal characteristics of an individual or the name or seal of an organization) that consumers are likely to believe reflects the opinions, beliefs, findings, or experiences of a party other than the sponsoring advertiser, even if the views expressed by that party are identical to those of the sponsoring advertiser").

${ }^{267}$ See Letter from Heather Hippsley, Acting Assoc. Dir. of Adver. Practices, FTC, to Gary Ruskin, Executive Dir., Commercial Alert (June 27, 2002), http:/www.ftc.gov/os/closings/staff/commercialalert attatch.shtm. The Hippsley letter, made in response to an official complaint by Commercial Alert, appears to be a less formal response than an official advisory opinion issued pursuant to 16 CFR $\S 1.5$ (2009), which permits the agency to issue "[i]ndustry guides [as] administrative interpretations of laws administered by the Commission for the guidance of the public in conducting its affairs in conformity with legal requirements." The letter includes the recommendations of the staff that search engines segregate organic results from those resulting from purchased AdWords. It is not considered an official advisory opinion, although it fulfills many of the same functions as an advisory opinion or industry guide (that is, it helps search engine companies avoid future official action from the FTC). See also Bracha \& Pasquale, supra note 65, at 1168-69 (discussing the implications of Ellen Goodman's work on "stealth marketing" for search engines); Andrew Sinclair, Note, Regulation of Paid Listings in Internet Search Engines: A Proposal for FTC Action, 10 B.U. J. SCI. \& TECH. L. 353, 355 (2004) ("As a result of 
always strictly separate "editorial content" and paid listings, subtler forms of manipulation could slip into their ranking algorithms. In many, if not most cases, consumers lack both the incentive and the ability to detect such manipulation. Given the lack of transparency of the search algorithms, search consumers simply cannot reverse engineer the hundreds of factors that go into a ranking, ${ }^{268}$ and they have little incentive to compare dozens of search results to assess the relative effectiveness and authenticity of different search engine results. ${ }^{269}$

New traffic management methods by carriers also challenge traditional conceptions of user autonomy. Generally, the digital information sent over the Internet is formatted into packets of data as specified by the Internet Protocol (IP), as opposed to sending the data as a long stream of bytes of information. ${ }^{270}$ Packets consist of a header and a payload, the latter corresponding to the substantive content of the information being sent. ${ }^{271}$

Traditionally, carriers did not inspect the content of the packets. However, carriers have begun to inspect the actual content of a consumer's transmitted or received data being sent over their networks by utilizing various technologies such as deep packet inspection and packet sniffing. Carriers may "inject" (or "spoof") additional packets into the data that their consumers are receiving so as to interfere with specific online activities (e.g., file sharing). ${ }^{272}$ These technologies allow carriers to command the type of insights into their customers' behavior once only achieved by search engines. ${ }^{273}$ The legacy of common carriage provides valuable precedents

congressional and administrative action, there are now specific guidelines in place requiring advertisers to make clear disclosures about the commercial nature of their content."); Douglas MacMillan, Blogola: The FTC Takes on Paid Posts, BUSINESSwEEK ONLINE, May 19, 2009, http://www.businessweek.com/ technology/content/may2009/tc20090518 532031.htm (discussing "advertising guidelines that will require bloggers to disclose when they're writing about a sponsor's product and voicing opinions that aren't their own").

${ }^{268}$ Niva Elkin-Koren, Let the Crawlers Crawl: On Virtual Gatekeepers and the Right to Exclude Indexing, 26 U. DAYTON L. REV. 179, 185 (2001) (discussing the difficulty of replicating a search engine's work).

${ }^{269}$ An effective search answers the searcher's query; authentic results are those unaffected by undisclosed commercial influences on the search engine's ranking of sites.

270 Lydia PARZIALE ET AL., INTERNATIONAL BUSINESS MACHINES, TCP/IP TUTORIAL AND TECHNICAL OVERVIEW, IBM CORP. 98-99 (2006), available at http://www.redbooks.ibm.com/red books/pdfs/gg243376.pdf.

271 Id

272 Peter Eckersley et al., Electronic Frontier found., Packet Forgery by ISPS: A REPORT ON THE COMCAST AFFAIR 1 (2007), http://www.eff.org/files/eff_comcast_report2.pdf.

${ }^{273}$ Rob Frieden, Internet Packet Sniffing and Its Impact on the Network Neutrality Debate and the Balance of Power Between Intellectual Creators and Consumers, 18 FORDHAM INTELL. PROP. MEDIA \& ENT. L.J. 633, 636-37 (2008) ("ISPs have upgraded, or soon will upgrade, their networks with hardware and software that enables them to acquire knowledge about what kinds of content they switch, route and transmit."); Tim Wu, Has AT\&T Lost Its Mind? A Baffling Proposal to Filter the Internet, SLATE, Jan. 16,2008 , http://www.slate.com/id/2182152. Wu criticizes AT\&T's announcement "that it is seriously considering plans to examine all the traffic it carries for potential violations of U.S. intellectual property 
for assuring some transparency in the development and implementation of technologies that monitor the content information transmitted over the Internet. ${ }^{274}$ As former FCC Chairman Michael Powell asserted, consumers have a right to "meaningful information regarding their service plans," including an understanding of exactly how they are being monitored and how their behavioral data is monetized. ${ }^{275}$

Search engines are referees in the millions of contests for attention that take place on the web each day. There are hundreds of entities that want to be the top result in response to a query like "sneakers," "top restaurant in New York City," or "best employer to work for." The top and right hand sides of many search engine pages are open for paid placement; but even there the highest bidder may not get a prime spot because a good search engine strives to keep even these sections relevant to searchers. ${ }^{276}$ The unpaid, organic results are determined by search engines' proprietary algorithms, though users often fail to distinguish between unpaid and paid placements. ${ }^{277}$ Businesses can grow reliant on good Google rankings as a way of attracting and keeping customers.

For example, John Battelle describes how the website 2bigfeet.com, a seller of large-sized men's shoes, was knocked off the first page of Google's results for terms like "big shoes" by a sudden algorithm shift in November 2003, right before the Christmas shopping season. ${ }^{278}$ Neil Moncrief, the site's owner, attempted to contact Google several times, but said he "never got a response." Google claimed that Moncrief may have hired a search engine optimizer who ran afoul of its rules, but it would not say pre-

laws. The prospect of AT\&T, already accused of spying on our telephone calls, now scanning every email and download for outlawed content is way too totalitarian for my tastes." Id.

${ }^{274}$ Catherine J.K. Sandoval, Disclosure, Deception, and Deep-Packet Inspection: The Role of the Federal Trade Commission Act's Deceptive Conduct Prohibitions in the Net Neutrality Debate, 78 FORDHAM L. REV. 641, 641 (2009) (exploring "the Federal Trade Commission (FTC) Act's proscriptions against deceptive conduct as a legal limit on Internet Service Provider (ISP) discrimination against Internet traffic," and arguing that the "Internet's architecture and codes presumed common carriage").

275 Powell, supra note 143, at 5; see also id. ("Providers have every right to offer a variety of service tiers with varying bandwidth and feature options. Consumers need to know about these choices as well as whether and how their service plans protect them against spam, spyware and other potential invasions of privacy.").

${ }^{276}$ Lastowka, supra note 34, at 1342-43 (describing current patterns of space allocation on search results).

277 Eric Goldman, Deregulating Relevancy in Internet Trademark Law, 54 EMORY L.J. 507, 518 (2005) ("Ultimately, searchers care only about the relevancy of the information they see, and artificial divisions between 'ads' and 'content' mask important similarities in the searcher's relevancy determination process."); Lastowka, supra note 34, at 1345 ("The [organic-paid] distinction . . is not important to the average user. In fact, the average Google user does not distinguish between the two types of links. According to one recent study, five out of six search engine users cannot tell the difference between sponsored links and organic results, and roughly half are unaware that a difference between the two exists.").

278 BATTELLE, supra note 35, at 156. 
cisely what those rules were. ${ }^{279}$ Just as the IRS is unwilling to disclose all of its "audit flags," Google did not want to permit manipulators to gain too great an understanding of how it detected their tactics.

So far claims like Moncrief's have not been fully examined in the judicial system, largely because Google has successfully deflected them by claiming that its search results embody opinions protected by the First Amendment. ${ }^{280}$ Several articles have questioned whether blanket First Amendment protection covers all search engine actions, ${ }^{281}$ and that conclusion has not yet been embraced on the appellate level in the United States. More importantly, even if state business tort claims are routinely rejected on First Amendment grounds, the FTC has the authority to protect consumers by revealing and prohibiting stealth marketing generally. ${ }^{282}$

The FTC was established to promote a level commercial playing field and has the authority to protect both consumers and competitors from "unfair or deceptive acts or practices in or affecting commerce." ${ }^{283}$ The FTC

279 Id. at 157 (describing Moncrief's efforts to find out why his site dropped in the rankings); see also Joe Nocera, Stuck in Google's Doghouse, N.Y. TIMES, Sept. 13, 2008, at C1 ("In the summer of 2006 . . . Google pulled the rug out from under [web business owner Dan Savage, who had come to rely on its referrals to his page, Sourcetool].... When Mr. Savage asked Google executives what the problem was, he was told that Sourcetool's 'landing page quality' was low. ... At a cost of several hundred thousand dollars, he made some of the changes Google suggested. No improvement."). Savage's company, TradeComet, sued Google for alleged violations of the antitrust laws. See Complaint, TradeComet.com LLC v. Google, Inc., No. 09 CIV. 1400 (S.D.N.Y. Feb. 17, 2009), 2009 WL 455244. The suit was dismissed on the basis of a forum selection clause. See TradeComet.com LLC v. Google, Inc., No. 09 CIV. 1400, 2010 WL 779325 (S.D.N.Y. Mar. 5, 2010).

${ }^{280}$ See Langdon v. Google, Inc., 474 F. Supp. 2d 622, 630 (D. Del. 2007) ("injunctive relief sought by Plaintiff contravenes Defendants' First Amendment rights"); Search King Inc. v. Google Tech., Inc., No. CIV-02-1457-M, 2003 WL 21464568, at*4 (W.D. Okla. May 27, 2003) ("The Court simply finds there is no conceivable way to prove that the relative significance assigned to a given web site is false. Accordingly, the Court concludes that Google's PageRanks are entitled to 'full constitutional protection."'). However, the FTC's top priority in its regulation seems to be consumer confusion. As evidenced by the First Amendment doctrine with regards to commercial speech, courts are willing to protect corporate speech insofar as it does not mislead consumers. See Cent. Hudson Gas \& Elec. Corp. v. Pub. Serv. Comm'n of N.Y., 447 U.S. 557, 563 (1980) (observing that commercial speech is afforded "a lesser protection ... than to other constitutionally guaranteed expression"). Thus, if consumer confusion could be proven (most likely with proven real repercussions, which would be more difficult), it is plausible that courts would be receptive to regulation.

${ }^{281}$ See, e.g., Jennifer Chandler, A Right to Reach an Audience: An Approach to Intermediary Bias on the Internet, 35 HOFSTRA L. REV. 1095, 1098 (2007) (describing indexed entities' First Amendment interests in an unbiased and open communicative forum); Frank Pasquale, Rankings, Reductionism, and Responsibility, 54 CLEV. ST. L. REV. 115, 125 (2006) (describing how blanket First Amendment protection for search engine rankings may not be appropriate).

282 Marla Pleyte, Online Undercover Marketing: A Reminder of the FTC's Unique Position to Combat Deceptive Practices, 6 U.C. DAVIS BuS. L.J. 14, 17 (2006) (“After analyzing common law solutions and state-level consumer protection regimes, this paper reaches the conclusion that the FTC is uniquely positioned to address [online business practices that are] pernicious and virtually undetectable.").

283 15 U.S.C. $\S 45(a)(2)(1914)$ ("The Commission is hereby empowered and directed to prevent persons, partnerships, or corporations, except . . . common carriers subject to the Acts to regulate commerce ...."). 
has shown a willingness to engage in regulation of online advertising in order to protect consumers. ${ }^{284}$ To ensure that ads are "clear and conspicuous," the agency advised advertisers to "[p]lace disclosures near, and when possible, on the same screen as the triggering claim [and] [u]se text or visual cues to encourage consumers to scroll down a Web page when it is necessary to view a disclosure. ${ }^{285}$ In the realm of stealth marketing in search engines or via ISP fast-tracking, the logical extension of this line of reasoning is a requirement that the intermediary disclose any consideration received in exchange for prominent placement (or more rapid delivery) of advertising or content. ${ }^{286}$

The FTC's extant guidance to search engines promoting the clear separation of organic and paid results suggests that the agency is beginning to assume these responsibilities. ${ }^{287}$ The FCC's response to Comcast's secretive blocking of BitTorrent reveals similar consumer protection concerns at that agency. While an opportunistic litigant could conceivably advance a First Amendment right to promote products or positions without indicating that the promotion has been paid for, such a challenge has not negated false advertising law, ${ }^{288}$ and even political speakers have been required to reveal their funding sources. ${ }^{289}$ Whatever substantive regulation may emerge, monitoring intermediaries' actions does not infringe on their free expression and may well enhance the autonomy and expressive capacities of users of these conduits.

284 The FTC report insists that "[d]isclosures that are required to prevent an ad from being misleading, to ensure that consumers receive material information about the terms of a transaction or to further public policy goals, must be clear and conspicuous." FTC, DOT COM DiSCLOSURES, supra note 16, at 1; see also Sinclair, supra note 267 , at 361 ("Though the FTC has not yet brought any actions against search engines for the use of paid listings, it has brought actions in parallel situations involving television and print content.").

${ }^{285}$ FTC, DOT COM DISCLOSURES, supra note $16, \uparrow 3$, at 1 . With regard to hyperlinks that "lead to disclosures," the link should be "obvious," appropriately labeled, and well-situated. Id. at 1-2.

286 The FTC clearly has jurisdiction over broadband providers, but does not have jurisdiction over entities subject to common carrier requirements. FTC STAFF REPORT, BROADBAND CONNECTIVITY COMPETITION POLICY 2-3 (2007) ("Regulatory jurisdiction over broadband services generally is subject to the shared jurisdiction of the FCC, the FTC, and the [DOJ] ... [S] ince about 2000, the FCC has undertaken a substantial and systematic deregulation of broadband services and facilities, concluding that cable, wireline, powerline, and wireless broadband Internet access services are 'information services' that are not subject to common carrier requirements. .. [T] [Tese decisions have served to reinforce and expand FTC jurisdiction over broadband Internet access services."). The FCC would need to impose such requirements on carriers presently subject to common carrier requirements.

287 See supra note 267.

${ }^{288}$ Rebecca Tushnet, It Depends on What the Meaning of "False" Is: Falsity and Misleadingness in Commercial Speech Doctrine, 41 LOY. L.A. L. REv. 227, 227 (2007) (remarking that "the governing law excludes false or misleading commercial speech from any First Amendment protection whatsoever").

289 Richard L. Hasen, Beyond Incoherence: The Roberts Court's Deregulatory Turn in FEC v. Wisconsin Right to Life, 92 MINN. L REV. 1064, 1107-08 (2008) ("In McConnell, the Justices voted 8-1 to uphold section 201 of the BCRA against an argument that compelled disclosure violated the First Amendment. Only Justice Thomas was swayed by that argument." (footnotes omitted)). 
Innovation and competition are only two of many tools we can use to encourage responsible and useful intermediaries. We should rely on them to the extent that (a) the intermediary in question is purely an economic (as opposed to cultural or political) force; (b) the "voice" of the intermediary's user community is strong; 290 and (c) competition is likely to be genuine and not contrived. ${ }^{291}$ For search engines and carriers, each of these factors strongly militates in favor of regulatory intervention. The FTC and FCC will need to recognize dominant carriers' and search engines' status as essential infrastructure for communication and connection.

Carriers and dominant general-purpose search engines are just as important to culture and politics as they are to economic life. As credence goods, they are not subject to many of the usual market pressures for transparency and accountability. They do not presently face many strong competitors, and are unlikely to do so in the immediate future. Their clear cultural power should lead scholars away from merely considering economies of scale and scope and network effects in evaluating these intermediaries' obligations. We need to consider all dimensions of network power here - the full range of cultural, political, and social obstacles to accountability that dominance can generate. ${ }^{292}$ Moreover, policymakers must acknowledge that competition itself can drive practices with many negative externalities.

\section{MONITORING AND ACCOUNTABILITY}

High-speed broadband connections and dominant search engines like Google are at the center of a storm of controversy over the obligations of Internet intermediaries. Most broadband markets are less than competitive. They abut other concentrated intermediary markets in general-purpose search, auctions, and social networking. ${ }^{293}$ In response to actual and potential abuses of that power, rules that would limit carriers' and intermediaries'

${ }^{290}$ Competition provides users an "exit" option; regulation gives them more of a "voice" in its governance. Albert O. Hirschman, Exit and Voice: An Expanding Sphere of Influence, in RIVAL VIEWS OF MARKET SOCIETY AND OTHER RECENT ESSAYS 77, 78-80 (1986) (describing "exit" and "voice" as two classic options of reform or protest). To the extent exit is available, voice (influence) within the relevant intermediary becomes less necessary; to the extent voice is available, exit becomes less necessary.

291 Broadband competition has failed to materialize beyond duopoly for most Americans. There are several reasons to suspect that Google's dominance of the general purpose search market will continue to grow. See Pasquale, Seven Reasons, supra note 223 (discussing self-reinforcing dominance of leading search engines).

292 DAVID SINGH GREWAL, NETWORK POWER 45 (2008) ("[T] he network power of English isn't the result of any intrinsic features of English (for example, 'it's easy to learn'): it's purely a result of the number of other people and other networks you can use it to reach.... The idea of network power ... explains how the convergence on a set of common global standards is driven by the accretion of individual choices that are free and forced at the same time.").

${ }^{293}$ For concentration statistics, see David S. Evans, Antitrust Issues Raised by the Emerging Global Internet Economy, 102 Nw. U. L. REV. COLLOQUY 285, 290 (2008) (citing COMSCORE, MYMETRIX KEY MEASURES REPORT (Dec. 2007)). 
ability to discriminate against certain applications providers or to unduly favor business partners are becoming increasingly necessary. Revelation of such discrimination when it occurs is a first step toward accountability; however, such transparency should be qualified in order to protect important intellectual property interests of intermediaries.

Advocates of network neutrality and other progressive forms of Internet governance now stand at a crossroads. They can continue to debate the issue in economic terms, developing ever more refined models of infrastructure and spillovers. Or they can shift the debate away from economic theory to the cultural, reputational, and political dynamics unleashed by new intermediaries. The economic debate on net neutrality should be complemented with careful analysis of the noneconomic consequences of untrammeled power for intermediaries. Such concerns do not dissolve even if carriers move away from commodity-provider status to integrate "smart networks" with tethered hardware, search, or other functionalities. The concerns apply a fortiori to dominant search engines which partner with carriers or achieve greater market share than physical infrastructure providers.

Given the secrecy of search engines' ranking algorithms and carriers' network management practices, it is very difficult for an entity to determine whether it has a "stealth marketing problem" online-i.e., a competitor that is somehow leveraging payments or business partnerships with intermediaries in order to gain greater relative exposure. ${ }^{294}$ Recognizing this problem, the FTC has taken some tentative steps toward addressing the potential for consumer deception and cultural distortion. In 2002, the agency sent a letter to various search engine firms recommending that they clearly and conspicuously distinguish paid placements from other results. ${ }^{295}$ But neither the FTC nor other potential regulators has followed up such guidance with genuine enforcement or systematic monitoring.

In order for the FTC to determine whether its guidance is actually being followed, it will need to develop sophisticated methods of understanding how organic results are determined. Without such an understanding, it will be impossible to distinguish between paid and organic content. This monitoring needs to happen in real time, rather than after a dispute arises, for many reasons. First, data retention may be spotty. Second, the history of regulation of high technology industries indicates that government lag in

294 Ellen P. Goodman, Stealth Marketing and Editorial Integrity, 85 TEX. L. REv. 83, 89 (2006) ("Stealth marketing ... [can take the form of] conventional payola, where the sponsor promotes a media experience, such as a musical work, by purchasing audience exposure to the experience as a form of advertisement. Pay-for-play in broadcasting is similar to the use of slotting fees in the retail industries to obtain preferential shelf space in supermarkets and book stores. Online retail outlets also use slotting fees of a sort when portals like Amazon and Google accept payments for exposure of a particular product or service.").

295 See Hippsley, supra note 267 (recommending that search engines segregate organic results from those resulting from purchased adwords); id. and accompanying text. 
understanding how critical infrastructure functions can effectively neuter even a strong regulatory regime. ${ }^{296}$ In response to such problems, Danny Weitzner (now the Associate Administrator of the Office of Policy Analysis and Development in the National Telecommunications and Information Administration) called for an "independent panel of technical, legal and business experts to help [the FTC] review, on an ongoing basis the privacy practices of Google."297 Such a panel could also develop the capacity for understanding the ranking practices of Google and the traffic management and monitoring done by internet service providers. This capacity could, in turn, enable litigants to submit focused queries to a nonbiased third party that could quickly give critical information to courts and agencies. ${ }^{298}$

A trusted advisory committee within the FTC could help courts and agencies adjudicate coming controversies over intermediary practices. Qualified transparency provides an excellent method for developing what Christopher Kelty calls a "recursive public"-one that is "vitally concerned with the material and practical maintenance and modification of the technical, legal, practical, and conceptual means of its own existence as a public."299 Questioning the power of a dominant intermediary is not just a preoccupation of the anxious. Rather, monitoring is a prerequisite for as-

296 See Robert Pitofsky, Chairman, FTC, Antitrust Analysis in High-Tech Industries: A 19th Century Discipline Addresses 21 st Century Problems, Address to American Bar Association Section of Antitrust Law's Antitrust Issues in High-Tech Industries Workshop (Feb. 1999), available at http://www.ftc.gov/speeches/pitofsky/hitch.shtm ("Many high-tech industries involve questions that are challenging for lawyers and judges who typically lack a technical background.").

297 Danny Weitzner's Blog, What to Do About Google and Doubleclick? Hold Google to Its Word with Some Extreme Factfinding About Privacy Practices, http:/dig.csail.mit.edu/breadcrumbs/blog/ 5?page=2 (Oct. 8, 2007, 11:24 EST) ("In the 1990s, the FTC under Christine Varney's leadership pushed operators of commercial websites to post policies stating how they handle personal information. That was an innovative idea at the time, but the power of personal information processing has swamped the ability of a static statement to capture the privacy impact of sophisticated services, and the level of generality at which these policies tend to be written often obscure the real privacy impact of the practices described. It's time for regulators to take the next step and assure that both individuals and policy makers have information they need."). This proposal could be integrated into current FTC practices. See Joseph Turow et al., The Federal Trade Commission and Consumer Privacy in the Coming Decade, 3 I/S J. L. \& POL'Y FOR INFO. SOC'Y 723, 727 (2007-2008) (describing an "impressive array of actions ... to prosecute unfair or deceptive trade practices").

298 Any proposal along these lines will eventually have to address skepticism about state-sponsored trusted entities, given the experience of those challenging trade secret-protected voting machine software. See David Levine, Trade Secrets in Our Public Infrastructure, 59 FLA. L. REV. 135, 183 (2007) ("[T]he notion that a government-controlled or designated entity could adequately protect the interests of the general public is dubious, and would turn on many variables that might undermine the third party's ability to operate in a completely public-oriented fashion. Indeed, where a state agency effectively nullifies a law designed to protect the public's interest, the entire basis upon which an escrow regime would be built - that is, trusting the entity charged with examining the escrowed material-is undermined. Thus, it is not readily apparent that a third-party (governmental or otherwise) might adequately protect the general interests of the public.").

299 Christopher M. Kelty, Two Bits: The Cultural Significance of Free Software 3 (2007). 
suring a level playing field online. As search engines increasingly become the hubs of traffic on the web and assert the same Communications Decency Act (CDA) and Digital Millennium Copyright Act (DMCA) immunities that carriers do, their actions need to become similarly subject to regulatory review. ${ }^{300}$

Undisclosed intermediary practices are a species of a larger genus of problems related to trade-secret-protected innovation that effectively regulates other forms of competition. ${ }^{301}$ Consumers compete for credit, and trade-secret-protected FICO scoring sorts them out for lenders; ${ }^{302}$ messages compete to land in our inboxes, and ISPs must deploy spam filters that sort the wheat from the chaff. In the public realm, undisclosed voting machine and breathalyzer software can determine which votes count and which do not, who goes to jail for drunk driving and who goes free. ${ }^{303}$

A developed literature on online worlds has considered in some detail whether law should intervene to regulate an online gaming company's regulation of its players' conduct. ${ }^{304}$ Legal systems have also developed a body of principles designed to regulate regulation, known as administrative law. ${ }^{305}$ Certain principles of openness and due process drawn from administrative law should govern private entities' management of competition. These principles are a natural extension of judicial practice in occasionally appointing special masters to handle trade secrecy discovery disputes. ${ }^{306}$

The growing importance of trade secrets in technologies of discipline and reward requires judges and policymakers to create nuanced regimes of

\footnotetext{
300 Pasquale, Internet Nondiscrimination Principles, supra note 12, at 266 (arguing "that the safe harbors that shield dominant search engines from liability also suggest patterns of responsibility for the results they present ... [because dominant search engines] and carriers are infrastructurally homologous ... [acting] simultaneously [as] stable conduits, dynamic cartographers, indexers, and gatekeepers of the Internet").

301 For a fuller exploration of this issue, see Pasquale, supra note 247.

302 MYFICO, UNDERSTANDING YOUR FICO SCORE 1 (2007), available at http://www.myfico.com/ Downloads/Files/myFICO_UYFS_Booklet.pdf (stating that a FICO score is a calculated number that allows lenders to estimate your credit risk).

${ }^{303}$ See Charles Short, Guilt By Machine: The Problem of Source Code Discovery in Florida DUI Prosecutions, 61 FLA. L. REV. 177, 179 (2009) ("[T] he state should negotiate for source code access to allow defendants to verify the machine's accuracy.").

304 See, e.g., THE STATE OF PLAY: LAW, GAMES, AND VIRTUAL WORLDS (Jack M. Balkin \& Beth Simone Noveck eds., 2006).

305 I owe this characterization of administrative law to University of Chicago law professor Tom Ginsburg's discussion of the topic in a podcast on Chinese administrative law. See Tom Ginsburg, Why China Allows Its Citizens to Sue the Government, http://uchicagolaw.typepad.com/faculty/2008/07/whychina-allow.html (University of Chicago Faculty Blog Podcast July 13, 2008, 6:09 PM).

${ }^{306}$ For more on special masters, see James R. McKown, Discovery of Trade Secrets, 10 SANTA CLARA COMPUTER \& HIGH TECH. L.J. 35, 45 (1994) ("Courts may appoint special masters to determine discovery disputes conceming trade secrets. In addition to the expressly enumerated methods, the official comment to the Act notes that courts also have restricted disclosures to a party's counsel and his or her assistants and have appointed a disinterested expert as a special master to hear secret information and report conclusions to the court.").
} 
qualified transparency. When ranking systems are highly complex and innovation is necessary (as in search engine algorithms and spam detection), a dedicated governmental entity should be privy to their development and should serve as an arbiter capable of providing guidance to courts that would otherwise be unable to assess complaints about the results the algorithm generates. ${ }^{307}$ If the Foreign Intelligence Surveillance Court can safely access critical national security information in a controlled environment in order to protect individual privacy from governmental intrusions, a similar entity should be privy to private sector activities that implicate the reputational and consumer protection interests described above. Given growing cooperation between federal authorities and intermediaries, the stakes of misrepresentation and mistake may be far more serious than the average commercial dispute. ${ }^{308}$

In the case of potential environmental hazards protected by trade secrets, a well-worn legal path has balanced citizen and consumer interests in transparency with corporate interests in secrecy. ${ }^{309}$ For example, Halliburton and other resource-extraction companies have been accused of using methods that could lead to the contamination of water sources. ${ }^{310}$ Halliburton's methods for extracting fuel have concrete value, which must in turn be balanced against the public interest in safe water and air. ${ }^{311}$ If the state went ahead and exposed the secret, the proprietary method might lose all economic value, but we can envision some process for compensating Halliburton for its loss.

The trade secrets of intermediaries are different in terms of the degree of damage done to the company and consumers by trade secret exposure. Their owners claim that if the trade secrets are released, the entire process they regulate will be gamed. ${ }^{312}$ In the worst case scenario, Google could

\footnotetext{
307 See Daniel J. Malooly, Physical Searches Under FISA: A Constitutional Analysis, 35 AM. CRIM. L. REV. 411, 412-14 (1998) (describing the operation of the Foreign Intelligence Surveillance Court).

${ }^{308}$ Michaels, supra note 251, at 938 n.167 (describing the identity and reputational harms of misidentification, misappropriation, dissemination, retaliation, and chilling effects).

309 Mary L. Lyndon, Information Economics and Chemical Toxicity: Designing Laws to Produce and Use Data, $87 \mathrm{MICH}$. L. REV. 1795, 1800-01 (1989) (critiquing the current balance as inadequately protective of public safety).

310 Abrahm Lustgarten, Gas Execs Call for Disclosure of Chemicals Used in Hydraulic Fracturing, PROPUBLICA, http://www.propublica.org/feature/gas-execs-call-for-disclosure-of-chemicals-used-inhydraulic-fracturing-102 ("It remains to be seen whether service providers such as Halliburton, and the chemical manufacturers that supply them, will go along with a movement toward disclosure .....").

311 Lyndon, supra note 309, at 1812 (describing the interplay of trade secrecy and takings doctrine).

312 An example from software technology anticipates intermediary arguments here. See Micah Schwalb, Exploit Derivatives \& National Security, 9 YALE J.L. \& TECH. 162, 184 (2007) ("Cisco used trade secret protection in 2005 to lever an out-of-court settlement that prevented disclosure of a potentially fatal vulnerability."); Carla Meninsky, Comment, Locked Out: the New Hazards of Reverse Engineering, 21 J. MARSHALL J. COMPUTER \& INFO. L. 591 (2003) (observing that that the DMCA actually limits reverse engineering and in essence enhances the scope of trade secrecy through an extension of copyright).
} 
become a graveyard of spammers, scammers, and "black hat search engine optimizers," all of whom raise the salience of their clients by tricking the algorithm into upping the rank of their clients' sites. Carriers could be overwhelmed by hackers, spam, and viruses. Each entity believes that its ordering of online life must be secret if it is to succeed in deterring bad actors.

We can interpret these worries about gaming in two very different ways. On the one hand, the trade secret owners claim guardianship over a process that is more than a mere game. ${ }^{313}$ Engineers prefer the rhetoric of science and markets: they are mathematically assessing the link structure and traffic of the Internet in order to satisfy consumer demands. ${ }^{314}$ Search engineers think of themselves as pursuing a "positivist, experimental science that has objectivity as an essential norm." ${ }^{315}$ But in contrast with natural science, which documents and explains regularities that will continue regardless of their being reported, the inherently social science of search can provoke changes in human behavior as soon as it is modeled. ${ }^{316}$ Complete openness in search or carriage methods risks opening these processes to a "spy versus spy" arms race of hacking and anticircumvention measures. $^{317}$

313 McKenzie Wark has discussed the negative connotations of the term "game" as applied to various aspects of life. See MCKENZIE WARK, GAMER THEORY 1.2, at 6-7 (2007) ("Everything has value only when ranked against another; everyone has value only when ranked against another. ... The real world appears as a video arcadia divided into many and varied games. Work is a rat race. Politics is a horse race. The economy is a casino. ... Games are no longer a pastime, outside or alongside of life. They are now the very form of life, and death, and time, itself.").

314 Elizabeth Van Couvering, Is Relevance Relevant? Market, Science, and War: Discourses of Search Engine Quality, 12 J. COMPUTER-MEDIATED COMM. 866, 871 (2007) ("[T]wo major schemas structure the development of search engine technology. The first I have chosen to call the market schema, because discourse in this schema refers mainly to business-related issues: costs, revenues, and competition. The second major schema I call the science-technology schema; its discourse is dominated by experiments, measures, proof, and utility.").

315 Id. at 874 .

316 The prospect of gaming reveals a key difference between the human and natural sciences: I can observe regularities in nature for some time and publication of my observations is not going to cause molecules or plants to act any differently. But strategic humans can change their behavior on the basis of knowledge about how others behave. As Jon Elster states, "In parametric rationality each person looks at himself as a variable and at all others as constants, whereas in strategic rationality all look upon each other as variables." Jon Elster, Marxism, Functionalism, and Game Theory: The Case for Methodological Individualism, 11 THEORY AND SOC'Y 453, 463 (1982).

317 The EU Privacy directive also recognizes this tension. See Council Directive 95/46, supra note 48, at I 41 ("Whereas any person must be able to exercise the right of access to data relating to him which are being processed, in order to verify in particular the accuracy of the data and the lawfulness of the processing; whereas, for the same reasons, every data subject must also have the right to know the logic involved in the automatic processing of data concerning him, at least in the case of the automated decisions referred to in Article 15 (1); whereas this right must not adversely affect trade secrets or intellectual property and in particular the copyright protecting the software; whereas these considerations must not, however, result in the data subject being refused all information."). 
Less commonly, but more tellingly, the rationale for "security via obscurity" embraces the gamelike quality of the enterprise. Google's guidelines for webmasters, and the very existence of "white hat," legitimate search engine optimizers, implies that some influencing of search engine results is acceptable. On this reading, there is a game in search engines, one that can be played fairly or cheated on. ${ }^{318}$ Rather than elevating the mapping project as more than a game, this view embraces its game-like qualities: follow the rules, generate enough interest from elsewhere on the web, and you can gradually win the search engine game.

Both the game-embracing and game-rejecting rationales for absolute trade secrecy are ultimately unconvincing. The putatively scientific aspiration to map the web hides the values at stake in the general purpose search engines' rankings. A search engine amounts to a cultural voting booth, translating the activities of millions of searchers and linkers into a referendum on the relevance of websites to any given query. Results in response to a company's or person's name paint a picture of that entity that can either raise or lower its profile and the esteem in which it is held. ${ }^{319}$

Meanwhile, the game-embracing viewpoint inadequately acknowledges the gray areas mentioned above. While the aleatory quality of a roll of the dice may increase the fun of playing Monopoly, something as serious as a business's relative position in search results based on trademarks it owns should not be similarly chancy.

In an era of increasing competitive pressures and income stratification, we like to believe that markets, democracy, or some combination of the two determine the results of these competitions. Those forms of spontaneous coordination are perceived as legitimate because they are governed by knowable rules. A majority or plurality of votes wins, as does the highest bidder. Yet when markets and elections are mediated by institutions that suffer transparency deficits, their legitimacy declines. Rather than being voluntarily reaffirmed by spontaneous choices of consumers, dominance can be purchased. To avoid such self-reinforcing cycles of advantage, both search engines' ranking practices and carriers' network management should be transparent to some entity capable of detecting both the illicit commodification of prominence and privacy-eroding practices engaged in by these intermediaries.

318 Van Couvering, supra note 314, at 877 (asserting that the "war schema ... provides a reflection on the identity of the producers as they assume the role of guardian or protector of something preciousin this case, access to the Web").

319 See Posting of Frank Pasquale to Concurring Opinions, The Picture and the Paint, http:// www.concurringopinions.com/archives/2009/01/the_picture_and.html (May 10, 2007, 12:26 EST) ("Iris Murdoch has stated that 'Man is a creature who makes pictures of himself and then comes to resemble the picture. This is the process which moral philosophy must attempt to describe and analyse.' But in [Lawrence] Lessig's [REMIX: MAKING ART AND COMMERCE THRIVE IN THE HYBRID ECONOMY (2008)], Google is the entity that makes pictures of our world (and ourselves), and we are invited to celebrate our participation in that process while downplaying the moral questions raised by its opaqueness."). 
There are some institutional precedents for the kind of monitoring that would be necessary to accomplish these goals. For example, the French Commission Nationale De L'Informatique et des Libertes (CNIL) has several prerogatives designed to protect the privacy of French citizens. ${ }^{320}$ For example, CNIL "ensure[s] that citizens are in a position to exercise their rights through information" by requiring data controllers to "ensure data security and confidentiality," to "accept on-site inspections by the CNIL," and to "reply to any request for information." 321 CNIL also grants individual persons rights to obtain information about the digital dossiers kept on them and their use. For example, CNIL explains that French law provides that:

Every person may, on simple request addressed to the organisation in question, have free access to all the information concerning him in clear language.

Every person may directly require from an organisation holding information about him that the data be corrected (if they are wrong), completed or clarified (if they are incomplete or equivocal), or erased (if this information could not legally be collected).

Every person may oppose that information about him is used for advertising purposes or for commercial purposes. ${ }^{322}$

320 Law No. 78-17 of January 6, 1978, J.C.P. 1978, III, No. 44692. English translation of law as amended by law of August 6, 2004, and by Law of May 12, 2009, available athttp://www.cnil.fr/fileadmin/documents/en/Act78-17VA.pdf, French language text modified through Law No. 2009-526 of May 12, 2009, J.O., May 13, 2009, available at http://www.cnil.fr/la-cnil/quisommes-nous/, French language consolidated version as of May 14, 2009, available at http://www.legifrance.gouv.fr/affichTexte.do?cidTexte $=$ JORFTEXT000000886460\& fastPos $=1 \&$ fastRe qId=826368234\&categorieLien=cid\&oldAction=rechTexte. Commission Nationale de l'Informatique et des Libertés (CNIL), founded by Law No. 78-17 of January 6, 1978, supra, is an independent administrative French authority protecting privacy and personal data held by government agencies and private entities. Specifically, CNIL's general mission consists of ensuring that the development of information technology remains at the service of citizens and does not breach human identity, human rights, privacy, or personal or public liberties.

${ }^{321} \mathrm{CNIL}$, Rights and Obligations, http://www.cnil.fr/english/the-cnil/rights-and-obligations/ (last visited Mar. 12, 2010). Specifically, Chapter 6, Article 44, of the CNIL-creating Act provides:

The members of the "Commission nationale de l'informatique et des libertés" as well as those officers of the Commission's operational services accredited in accordance with the conditions defined by the last paragraph of Article 19 (accreditation by the commission), have access, from 6 a.m to 9 p.m, for the exercise of their functions, to the places, premises, surroundings, equipment or buildings used for the processing of personal data for professional purposes, with the exception of the parts of the places, premises, surroundings, equipment or buildings used for private purposes.

Law No. $78-17$ of January 6, 1978, J.C.P. 1978, III, No. 44692, ch. 6, art. 44, available at http://www.cnil.fr/fileadmin/documents/en/Act78-17VA.pdf, at 30.

322 CNIL, Rights and Obligations, supra note 321. 
While the United States does not have the same tradition of protecting privacy prevalent in Europe, ${ }^{323}$ CNIL's aims and commitments could prove worthwhile models for U.S. agencies. ${ }^{324}$

U.S. policymakers may also continue to experiment with publicprivate partnerships to monitor problematic behavior at search engines and carriers. For instance, the National Advertising Division (NAD) of the Council of Better Business Bureaus is a "voluntary, self-regulating body" that fields complaints about allegedly untruthful advertising. ${ }^{325}$ The vast majority of companies investigated by NAD comply with its recommendations, but can resist its authority and resolve the dispute before the FTC. ${ }^{326}$ Rather than overwhelming the agency with adjudications, the NAD process provides an initial forum for advertisers and their critics to contest the validity of statements. ${ }^{327}$ NAD is part of a larger association called the $\mathrm{Na}$ tional Advertising Review Council (NARC), which promulgates procedures for NAD, the Children's Advertising Review Unit (CARU), and the National Advertising Review Board (NARB). ${ }^{328}$

Instead of an "Innovation Environment Protection Agency (iEPA)" (the agency Lawrence Lessig proposed to supplant the FCC) ${ }^{329}$ I would recommend the formation of an Internet Intermediary Regulatory Council

323 James Whitman, The Two Western Cultures of Privacy: Dignity Versus Liberty, 113 YALE L.J. 1151,1155 (2004) (comparing U.S. and European privacy law).

${ }^{324}$ For example, CNIL has not shied away from using its powers to investigate Google. CNIL, Street View: la CNIL met en demeure Google de lui communiquer les données Wi-Fi enregistrées, http://www.cnil.fr/vos-responsabilites/le-controle-de-a-a-z/actualites/article/17/street-view-la-cnil-meten-demeure-google-de-lui-communiquer-les-donnees-wi-fi-enregistrees/ (describing CNIL's response to complaints about Googles's "street view" project).

325 Seth Stevenson, How New Is New? How Improved Is Improved? The People Who Keep Advertisers Honest, SLATE, July 13, 2009, http://www.slate.com/id/2221968.

${ }^{326}$ Id. ("When an ad is brought to their attention, the NAD's lawyers review the specific claims at issue. The rule is that the advertiser must have substantiated any claims before the ad was put on the air, so the NAD will first ask for any substantiating materials the advertiser can provide. If the NAD lawyers determine that the claims aren't valid, they'll recommend that the ad be altered. The compliance rate on this is more than 95 percent. But if the advertiser refuses to modify the ad (this is a voluntary, self-regulating body, not a court of law), the NAD will refer the matter to the Federal Trade Commission. One such FTC referral resulted in an $\$ 83$ million judgment against a weight-loss company.").

327 Id.

328 NATIONAL ADVERTISING REVIEW COUNCIL, THE ADVERTISING INDUSTRY'S PROCESS OF Voluntary Self-Regulation: Policies and Procedures \$2.1(a) (July 27, 2009) ("The National Advertising Division of the Council of Better Business Bureaus (hereinafter NAD), and the Children's Advertising Review Unit (CARU), shall be responsible for receiving or initiating, evaluating, investigating, analyzing (in conjunction with outside experts, if warranted, and upon notice to the parties), and holding negotiations with an advertiser, and resolving complaints or questions from any source involving the truth or accuracy of national advertising."). Though billed as "self-regulation," it is difficult to see how the policy would have teeth were it not self-regulation in the shadow of an FTC empowered by the Lanham Act to aggressively police false advertising. The FTC has several mechanisms by which to regulate unfair business practices in commerce. See, e.g., 15 U.S.C. § 45(b) (2006) (giving the commission the authority to register an official complaint against an entity engaged in unfair business methods).

329 See supra note 101. 
(IIRC), which assists both the FCC and FTC in carrying out their present missions. ${ }^{330}$ Like the NARC, the IIRC would follow up on complaints made by competitors, the public, or when it determines that a practice deserves investigation. If the self-regulatory council failed to reconcile conflicting claims, it could refer complaints to the FTC (in the case of search engines, which implicate the FTC's extant expertise in both privacy and advertising) or the FCC (in the case of carriers). In either context, an IIRC would need not only lawyers, but also engineers and programmers who could fully understand the technology affecting data, ranking, and traffic management practices.

The IIRC would research and issue reports on suspect practices at Internet intermediaries, while respecting the intellectual property of the companies it investigated. An IIRC could generate official and even public understanding of intermediary practices, while keeping crucial proprietary information under the control of the companies it monitors. An IIRC could develop a detailed description of safeguards for trade secrets, which would prevent anyone outside its offices from accessing the information. ${ }^{331}$ Another option would be to allow IIRC agents to inspect such information without actually obtaining it. An IIRC could create "reading rooms" for its experts to utilize, just as some courts allow restrictive protective orders to govern discovery in disputes involving trade secrets. The experts would review the information in a group setting (possibly over a period of days) to determine whether a given intermediary had engaged in practices that could constitute a violation of privacy or consumer protection law. Such review would not require any outside access to sensitive information.

I prefer not to specify at this time whether an IIRC would be a private or public entity. Either approach would have distinct costs and benefits explored (in part) by a well-developed literature on the role of private entities in Internet governance. ${ }^{332}$ Regardless of whether monitoring is done by a governmental entity (like CNIL) or an NGO (like NARC), we must begin developing the institutional capacity to permit a more rapid understanding of intermediary actions than traditional litigation permits. ${ }^{333}$

${ }^{330}$ It could include a Search Engine division, an ISP division focusing on carriers, and eventually divisions related to social networks or auction sites if their practices begin to raise commensurate concerns.

331 This is the way that the NAD proceeds. It provides specific procedures under which the participants can request that certain sensitive information be protected. See NAT'L ADVERTISING REVIEW

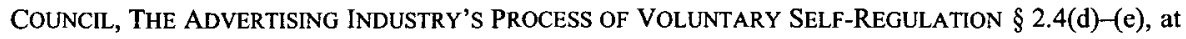
4-5 (2009), http://www.nadreview.org/07_Procedures.pdf (discussing procedure for confidential submission of trade secrets).

332 See, e.g., Philip J. Weiser, Internet Governance, Standard Setting, and Self-Regulation, 28 N. KY. L. REV. 822, 822 (2001) (examining "in particular the nature and limits of a key private regulator of the Internet: standard-setting organizations and their institution of open, interoperable standards").

${ }^{333}$ Google has already recognized the need for some kind of due process in response to complaints about its labeling of certain websites as "harmful" (due to the presence of viruses or other security threats at the sites) via the Stop Badware program. See ZITTRAIN, supra note 30, at 171 ("Requests for 
It is not merely markets and antitrust enforcement that are insufficient to constrain problematic intermediary behavior-the common law is also likely to fall short. It is hard to imagine any but the wealthiest and most sophisticated plaintiffs' attorneys attempting to understand the tweaks to the Google algorithm that might have unfairly diminished their clients' sites' salience. Trade secrets have been deployed in the context of other litigation to frustrate investigations of black box algorithms. ${ }^{334}$ Examination of Google's algorithms subject to very restrictive protective orders would amount to a similar barrier to accountability; given its recent string of litigation victories, it is hard to imagine rational litigants continuing to take on that risk. Moreover, it makes little sense for a court to start from scratch in understanding the complex practices of intermediaries when an entity like the IIRC could develop lasting expertise in interpreting their actions.

A status quo of unmonitored intermediary operations is a veritable "ring of Gyges," tempting them to push the envelope with privacy practices which cannot be discovered by their victims. Distortions of the public sphere are also likely. While a commercially influenced "fast-tracking" or "up-ranking" of some content past others might raise suspicions among its direct (but dispersed) victims, the real issues it raises are far broader. If an online ecology of information that purports to be based on one mode of ordering is actually based on another, it sets an unfair playing field whose biases are largely undetectable by lay observers. Stealth marketing generates serious negative externalities that menace personal autonomy and cultural authenticity. Moreover, the degree of expertise necessary to recognize these externalities in the new online environment is likely to be possessed by only the most committed observers.

This potent combination of expertise and externalities is a classic rationale for regulation. As Danny Weitzner's proposal for "extreme factfinding" (in the context of the Google-DoubleClick merger review) recognized, only a dedicated group of engineers, social scientists, attorneys, and computer scientists are likely to be adept enough at understanding search engine decisions as a whole to understand particular complaints

review - which included pleas for help in understanding the problem to begin with -inundated StopBadware researchers, who found themselves overwhelmed in a matter of days by appeals from thousands of Web sites listed. Until StopBadware could check each site and verify it had been cleaned of bad code, the warning page stayed up."). Google's cooperation with the Harvard Berkman Center for Internet Research to run the Stop Badware program could prefigure future intermediary cooperation with NGOs to provide "rough justice" to those disadvantaged by certain intermediary practices.

334 See Jessica Ring Amunson \& Sam Hirsch, The Case of the Disappearing Votes: Lessons from the Jennings v. Buchanan Congressional Election Contest, 17 WM. \& MARY BILL RTS. J. 397, 397-98 (2008) ("[T]he litigation ultimately was utterly inconclusive as to the reason for the 18,000 electronic undervotes because discovery targeting the defective voting system was thwarted when the voting machines' manufacturer successfully invoked the trade-secret privilege to block any investigation of the machines or their software by the litigants."); Short, supra note 303, at 179 ("[T] tiate for source code access to allow defendants to verify the machine's accuracy."). 
about them. ${ }^{335}$ Someone needs to be able to examine the finer details of the publicly undisclosed operation of culturally significant automated ranking systems-that is, to watch those who watch and influence us. ${ }^{336}$

\section{CONCLUSION}

ISPs and search engines have mapped the web, accelerated ecommerce, and empowered new communities. They also pose new challenges for law. This Article has both built on and critiqued extant cyberlaw literature focused on the legal disputes between these intermediaries. The dominant focus on interbusiness conflicts is losing relevance as entities cooperate more in mergers and joint ventures. While such cooperation can be economically efficient, it has many troubling consequences for users. Individuals are rapidly losing the ability to affect their own image on the web, or even to know what data others are presented with regarding them. When web users attempt to find information or entertainment, they have little assurance that a carrier or search engine is not subtly biasing the presentation of results in accordance with its own commercial interests.

Those skeptical of the administrative state may find a proposal to "watch the watchers" problematic. ${ }^{337}$ They think of intermediaries as primarily market actors, to be disciplined by market constraints. However, the development of dominant Web 2.0 intermediaries was itself a product of particular legal choices about the extent of intellectual property rights and the responsibilities of intermediaries made in legislative and judicial decisions in the 1990s. As intermediaries gained power, various entities tried to bring them to heel-including content providers, search engine optimizers,

335 Weitzner, supra note 297. Weitzner proposes that "[r] egulators should appoint an independent panel of technical, legal and business experts to help them review, on an ongoing basis the privacy practices of Google." Id. The panel would be "made up of those with technical, legal and business expertise from around the world." Id. It would hold "public hearings at which Google technical experts are available to answer questions about operational details of personal data handling." Id. There would be "staff support for the panel from participating regulatory agencies," "real-time publication of questions and answers," and "[a]n annual report summarizing what the panel has learned." Id.

336 In the meantime, Google has been developing a tool that would help consumers detect if their Internet service provider was "running afoul of Net neutrality principles." Stephanie Condon, GoogleBacked Tool Detects Net Filtering, Blocking, CNET News, Jan. 28, 2009, http://news.cnet.com/830113578 3-10152117-38.html ("[The tool, M-Lab,] is running three diagnostic tools for consumers: one to determine whether BitTorrent is being blocked or throttled, one to diagnose problems that affect lastmile broadband networks, and one to diagnose problems limiting speeds."). It remains to be seen whether Google itself would submit to a similar inspection to determine whether it was engaging in stealth marketing or other problematic practices.

337 See, e.g., Posting of Berin Szoka to the Blog of the Progress \& Freedom Foundation, Net Neutrality Regulation $\Rightarrow>$ Online Product/Service Definitions $\Rightarrow$ Online Taxation, http://blog.pff.org/arch ives $/ 2009 / 09 /$ net_neutrality_regulation_online_productservice_de.html (Sept. 30, 2009, 9:40 EST) ("[T] ber-collectivist 'luminaries' like Jonathan Zittrain and Frank Pasquale demanding neutrality regulation for devices, application platforms like iTunes and Facebook, and search!"). 
trademark owners, and consumer advocates. In traditional information law, claims under defamation and copyright law might have posed serious worries for these companies. However, revisions of communications and intellectual property law in the late 1990s provided safe harbors that can trump legal claims sounding in each of these other areas. ${ }^{338}$ Some basic reporting responsibilities are a small price to pay for continuing enjoyment of such immunities.

Any policy analysis of dominant intermediaries should recognize the sensitive cultural and political issues raised by them. While economics proceeds on a paradigm of maximizing consumer welfare, this goal is but one of many dimensions along which intermediary performance should be measured. Neither the FTC nor the FCC presently has the type of technical and social scientific expertise necessary to address these concerns. Qualified transparency of intermediary practices would assist policymakers and courts that seek to address the cultural, reputational, and political effects of their dominance.

Economic analysis of network neutrality has focused on comparisons of the Internet to utilities and infrastructural transportation facilities like freeways, trains, postal services, and airports. Yet the online world fundamentally differs from the transport and energy sectors - it has more cultural impact and political consequences. Carriers and search engines determine how well individuals can connect to a metaverse of ideas, entertainment, and common interests. New practices like deep packet inspection raise privacy concerns different than Transportation Security Administration screening or EZ-Pass monitoring. These concerns cannot be integrated into conventional economic analysis and provide alternative, noneconomic grounds for comprehensive monitoring of carriers and search engines. Someone must watch the watchers.

Dominant search engines and ISPs are the critical infrastructure for contemporary culture and politics. As these dominant intermediaries have gained more information about their users, they have shrouded their own business practices in secrecy. Internet policy needs to address the resulting asymmetry of knowledge and power. Yet before they make substantive rules, key administrators must genuinely understand new developments.

While the FTC and the FCC have articulated principles of editorial integrity in search engines and net neutrality for carriers, they have not engaged in the monitoring necessary to enforce these guidelines. Privacy protection in the digital age also requires regulators capable of fully under-

338 See Digital Millennium Copyright Act of 1998, 17 U.S.C. $\S 512$ (d) (2006) (safe harbor); Communications Decency Act of 1997, 47 U.S.C. $\$ 230$ (c)(1) (2006) (safe harbor for intermediaries). For critical commentary on the latter, see Michael L. Rustad \& Thomas H. Koenig, Rebooting Cybertort Law, 80 WASH. L. REV. 335, 371 (2005) ("An activist judiciary, however, has radically expanded $\S 230$ by conferring immunity on distributors. Section $230(\mathrm{c})(1)$ has been interpreted to preclude all tort lawsuits against ISPs, websites, and search engines. Courts have ... haphazardly lump[ed] together web hosts, websites, search engines, and content creators into this amorphous category."). 
standing intermediaries' data practices. Monitoring based on a principle of qualified transparency would fill these regulatory gaps. Qualified transparency respects legitimate needs for confidentiality while promoting individuals' capacity to understand how their reputations - and the online world generally—are shaped by dominant intermediaries. 
NORTHWESTERN UNIVERSITY LA W REVIEW 